CRISTIANE DE ARAÚJO MARTINS MORENO

\title{
Estudo clínico, histológico e molecular na miopatia congênita nemalínica e na miopatia congênita com alterações mínimas
}

\author{
Tese apresentada a Faculdade de \\ Medicina da Universidade de São Paulo \\ para obtenção de título de Doutor em \\ Ciências
}

Programa de Neurologia

Orientador: Prof. Dr. Edmar Zanoteli

São Paulo.

2016. 
Dados Internacionais de Catalogação na Publicação (CIP)

Preparada pela Biblioteca da

Faculdade de Medicina da Universidade de São Paulo

Creprodução autorizada pelo autor

\section{Moreno, Cristiane de Araújo Martins}

Estudo clínico, histológico e molecular na miopatia congênita nemalínica e na miopatia congênita com alterações mínimas / Cristiane de Araújo Martins Moreno. -São Paulo, 2016.

Tese(doutorado)--Faculdade de Medicina da Universidade de São Paulo. Programa de Neurologia.

Orientador: Edmar Zanoteli.

Descritores: 1.Miopatias congênitas estruturais 2.Miopatias congênitas estruturais/diagnóstico 3. Miopatias congênitas estruturais/histologia 4.Miopatias da nemalina 5.Músculos/biópsia 6.Doenças musculares 7.Estudo clínico

USP/FM/DBD-359/16 
Dedicatória

A minha família 


\section{Agradecimentos especiais,}

Agradeço ao Dr. Edmar pela dedicação e minúcia ao acompanhar todo o desenvolvimento do trabalho, pelas horas dedicadas, pelo carinho e também pela severidade.

A Dra Umbertina que me inspirou com seu conhecimento, dedicação e zelo pelos pacientes. Sua ternura vai me acompanhar para sempre na clínica.

Ao Dr Carsten Bonnemann que ampliou meus horizontes e me incentivou a ir cada vez mais adiante na pesquisa.

Aos Drs. Acary Souza Bulle, Ana Beatriz Perez e Fernando Kok, agradeço a sua disponibilidade e objetividade. Seus direcionamentos foram fundamentais na estruturação do trabalho.

A minha mãe, minha grande heroína, que jamais teve dúvidas da minha capacidade, a minha madrinha Cristine, que direcionou meu caminho, e também a todo o restante da minha família que me deu suporte e amor apesar das minhas constantes ausências.

Um agradecimento especial ao Marcio, meu esposo, meu amor, meu maior orgulho. Seu encorajamento, seus comentários diplomáticos e sua matemática estão presentes em cada capítulo deste trabalho.

Agradeço ainda a todos que contribuiram de alguma forma com este trabalho: Dr Osório, Dra Jéssica, Dra Mary, Eliene, Eduardo, André, Rodrigo, Marco, Cláudio, Juliana, Florence, Alan, Francisco Dr. Gerson, Ying, Yahun e Sandra. Vocês estarão para sempre no meu coração. 
"Scientists often have a naive faith that if only they could discover enough facts about a problem, these facts would somehow arrange themselves in a compelling and true solution."

-Theodosius Dobzansky. 


\section{NORMATIZAÇÃO ADOTADA}

Esta tese está de acordo com as seguintes normas, em vigor no momento dessa publicação:

Referências - adaptado de International Committee of Medical Journals Editors (Vancouver).

Universidade de São Paulo. Faculdade de Medicina. Divisão de Biblioteca e Documentação. Guia de apresentação de dissertações, teses e monografias. Elaborado por Anneliese Carneiro da Cunha, Maria Júlia de A. L. Freddi, Maria F. Crestana, Marinalva de Souza Aragão, Suely Campos Cardoso, Valéria Vilhena. 3a ed. São Paulo: Divisão de Biblioteca e Documentação; 2011.

Abreviaturas dos títulos de periódicos de acordo com List of Journals indexed in Index Medicus. 


\section{SUMÁRIO}

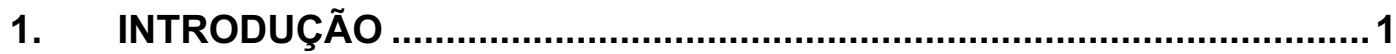

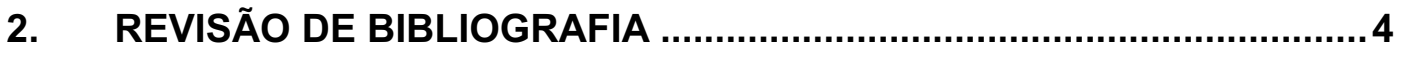

2.1 MIOPATIAS CONGÊNITAS.............................................................. 4

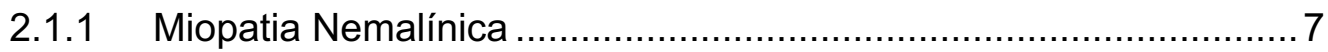

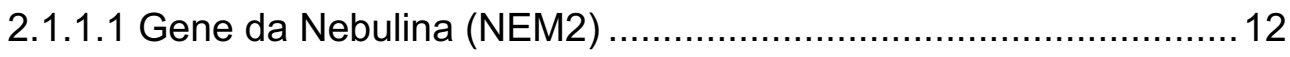

2.1.1.2 Gene da Alfa-actina (NEM3) ................................................ 14

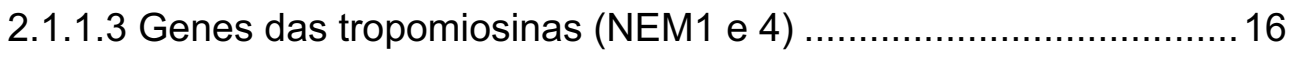

2.1.1.3.1 Alfa-tropomiosina lenta (NEM1) …………….................. 17

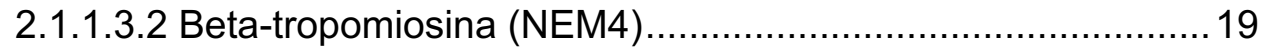

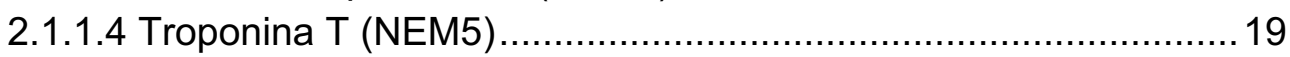

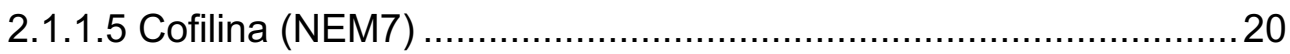

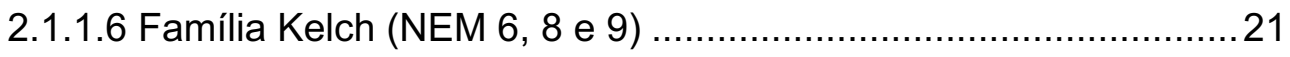

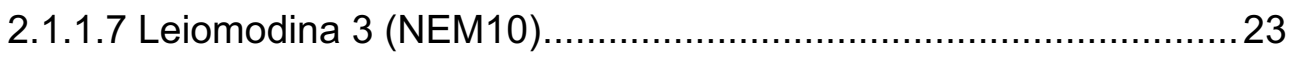

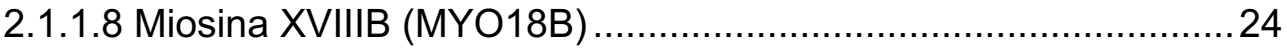

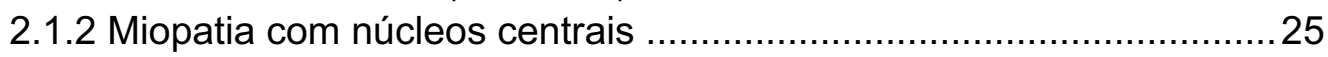

2.1.3 Miopatia com presença de cores .................................................2

2.1.4 Miopatias com variação no tamanho das fibras e achados

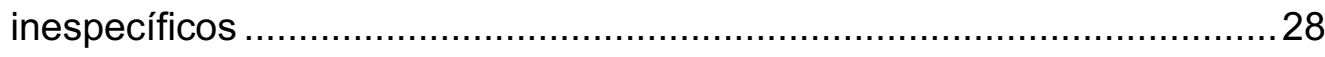

2.1.5 Diagnóstico diferencial das miopatias congênitas .............................30

2.1.6 Abordagens no tratamento das miopatias congênitas........................32

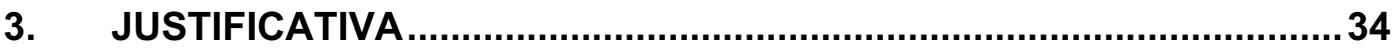

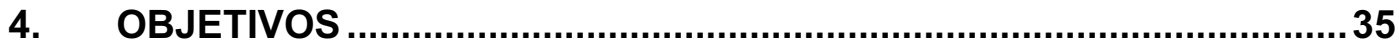

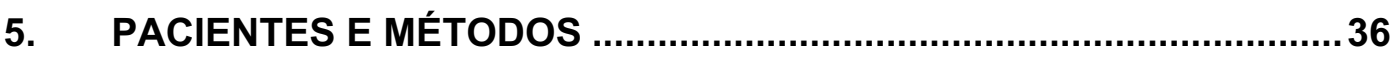

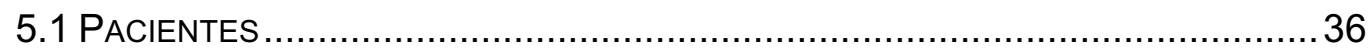

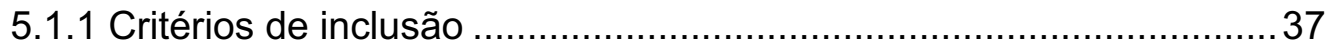

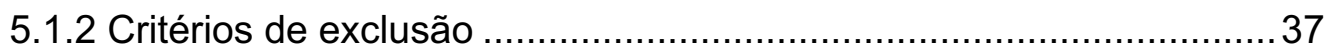

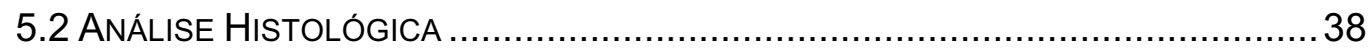

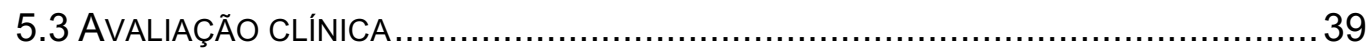

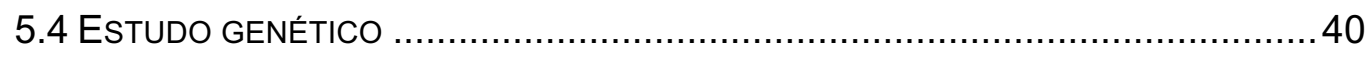

5.4.1 Extração de DNA e sequenciamento Sanger ..................................4 40

5.4.2 Sequenciamento dos genes ACTA1, MYH7, TPM3 e SEPN1 ......... 41

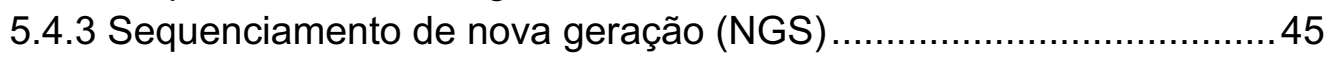

5.4.4 Algoritimo para o estudo genético ……........................................ 48

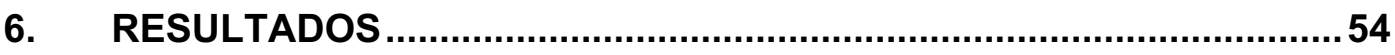

6.1 DESCRIÇÃO CLÍNICA E HISTOLÓGICA DOS PACIENTES COM MN ......................54

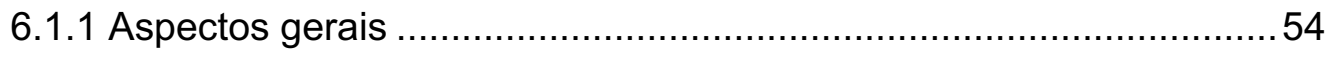

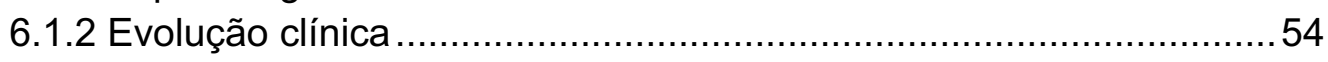

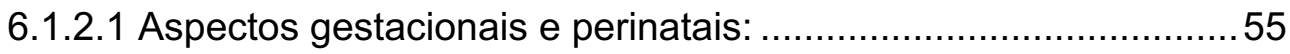




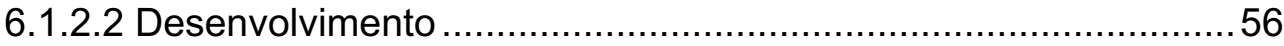

6.1.2.3 Evolução ............................................................................ 56

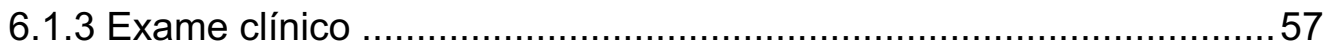

6.1.4 Exames complementares e biópsia muscular ...............................59

6.1.4.1 Exames complementares ................................................ 59

6.1.4.2 Biópsia muscular ............................................................... 60

6.1.5 Reabilitação e escolaridade ..................................................... 61

6.2 DESCRIÇÃO CLÍNICA E HISTOLÓGICA DOS PACIENTES COM MCI ....................73

6.2.1 Aspectos gerais .................................................................. 73

6.2.2 Evolução clínica .............................................................. 73

6.2.2.1 Aspectos gestacionais e perinatais ....................................... 73

6.2.2.2 Desenvolvimento e evolução............................................. 74

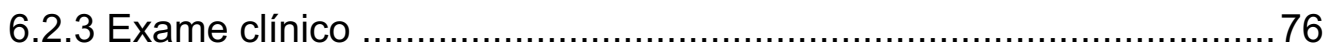

6.2.4 Exames complementares e biópsia muscular ............................. 77

6.2.4.1 Exames complementares .................................................. 77

6.2.4.2 Biópsia muscular ............................................................... 77

6.2.5 Reabilitação e escolaridade .................................................... 78

6.3 RESULTADOS DO ESTUDO GENÉTICO ................................................. 89

6.3.1 Pacientes com mutações no gene ACTA1 ....................................91

6.3.2 Pacientes com variante patogênica no gene NEB ..........................99

6.3.3 Pacientes com variante patogênica no gene CHRNE ..................... 104

6.3.4 Pacientes com variante patogênica no gene TPM3 ......................106

6.3.5 Pacientes com mutação no gene RYR1 ...................................... 109

6.3.6 Paciente com mutação no gene TTN .........................................112

6.3.7 Pacientes com variante patogênica no gene MYH7 .....................114

7. DISCUSSÃO .............................................................................. 120

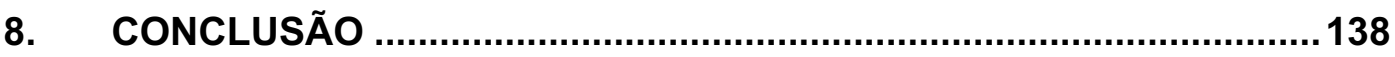

9. ANEXO: FICHA DE ATENDIMENTO PADRÃO DO AMBULATÓRIO DE DOENÇAS NEUROMUSCULARES FMUSP........................................... 140

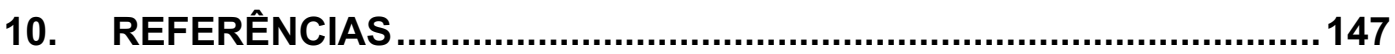




\section{LISTA DE SIGLAS}

ATPase Adenosina trifosfatase

BAM Do inglês, binary alignment map

CAPPesq Comissão de Ética para Análise de Projetos de Pesquisa

COX Citocromo oxidase

CPK Creatina fosfoquinase

CVF Capacidade vital forçada

DCTF Desproporção congênita de tipo de fibras

DM Distrofia miotônica

DM1 Distrofia miotônica tipo 1

DNA Do inglês, deoxyribonucleic acid

DNPM Desenvolvimento neuropsicomotor

dNTP Deoxinucletídeo trifosfato

ENMC Do inglês, International Consortium on Nemaline Myopathy

ENMG Eletroneuromiografia

EVS Do inglês, exome variant server

FMUSP Faculdade de Medicina da Universidade de São Paulo

GOM Tricrômico de Gömöri

HE Hematoxilina e eosina

HGMD Do inglês, human genome mutation database

HLA Do inglês, human leukocyte antigen

LIM Laboratório de Investigações Médicas

LOVD Do inglês, Leiden Open Variation Database 
$\mathrm{MCl}$ Miopatia congênita com achados inespecíficos

MCN Miopatia centronuclear

MIM Do inglês, Mendelian Inheritance in Men

MN Miopatia nemalínica

MRC Do inglês, Medical Research Council

MTM Miopatia miotubular

NADH-TR Nicotinamida adenina trinucleotídeo tetrazolium redutase

NGS Do ingês, next generation eequencing

NINDS/NIH Do inglês, National Institute of Neurologicla Disorders/National Institute of Health

OMIM Do inglês, Online Mendelian Inheritance in Men

OMS Organização Mundial de Saúde

ORO Do inglês, Oil Red O

PAS Do inglês, periodic acid Schiff

PCR Do inglês, polymerase chain reaction

RNAm Do inglês, messenger ribonucleic acid

SDH Succinato desidrogenase

SE Sequenciamento exômico

SLONM, Do inglês slowly late onset nemaline myopathy

SMC Síndrome de miastenia congênita

UNIFESP Universidade Federal de São Paulo

UTI Unidade de terapia intensiva

VCF Do inglês, variant call format 


\section{LISTA DE ABREVIATURAS}

ug Micrograma

$\mu \mathrm{L}$ Microlitro

$\mu \mathrm{M}$ Micromolar

$\mathrm{mL}$ Mililitro

mM Milimolar

ng Nanograma

pmol Picomolar

U Unidade de medida 
$\mathrm{XVI}$

\section{LISTA DE DIAGRAMAS}

Diagrama 1 - Esquema do estudo genético dos pacientes com MN mostrando o local onde cada etapa foi realizada.

Diagrama 2 - Esquema do estudo genético dos pacientes com $\mathrm{MCl}$ sem espinha rígida (grupo 1) e com espinha rígida (grupo 2) mostrando o local onde cada etapa foi realizada.

52

Diagrama 3 - Esquema do estudo genético dos pacientes com $\mathrm{MCl}$ com achados clínicos atípicos (grupo 3 ). 


\section{LISTA DE GRÁFICOS}

Gráfico 1 - Principais características clínicas (história clínica, exame físico e queixas atuais) dos pacientes com $\mathrm{MN}(\mathrm{N}=23)$.

Gráfico 2 - Grupos musculares mais gravemente afetados - fraqueza muscular grave (força MRC menor/igual a III) nos pacientes com $\mathrm{MN}(\mathrm{N}=23)$.

Gráfico 3 - Exames complementares dos pacientes com $\mathrm{MN}(\mathrm{N}=23)$. 68

Gráfico 4 - Principais características histológicas observadas na análise da biópsia muscular dos pacientes com $\mathrm{MN}(\mathrm{N}=23)$. 68

Gráfico 5 - Escolaridade e reabilitação dos pacientes com $\mathrm{MN}(\mathrm{N}=23)$...........69

Gráfico 6 - Principais características clínicas dos pacientes com $\mathrm{MCl}(\mathrm{N}=22) .83$

Gráfico 7 - Exames complementares dos pacientes com $\mathrm{MCl}(\mathrm{N}=22)$. 84

Gráfico 8 - Principais achados na biópsia muscular dos pacientes com $\mathrm{MCl}$ $(\mathrm{N}=22)$. 85

Gráfico 9 - Escolaridade e reabilitação dos pacientes com $\mathrm{MCl}(\mathrm{N}=22)$. .85 


\section{LISTA DE FIGURAS}

Figura 1 - Estrutura esquemática do sarcômero …………………………....13

Figura 2 - Características clínicas gerais dos pacientes com MN ...................70

Figura 3 - Características gerais da biópsia muscular dos pacientes com MN 71

Figura 4 - Heredogramas das famílias da coorte de MN.............................72

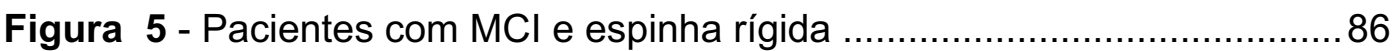

Figura 6 - Principais achados histológicos em biópsia muscular de pacientes

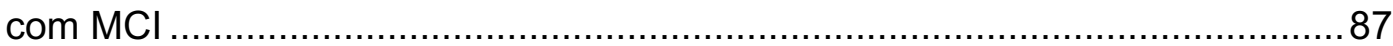

Figura 7 - Heredogramas das famílias da coorte de $\mathrm{MCl}$..............................8

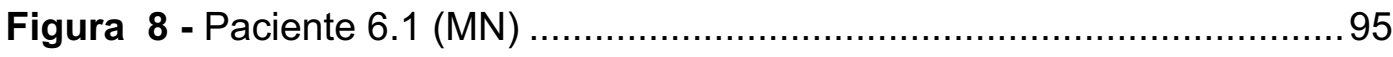

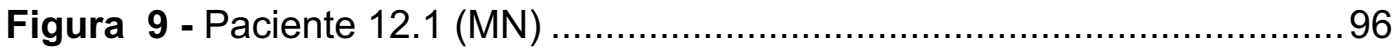

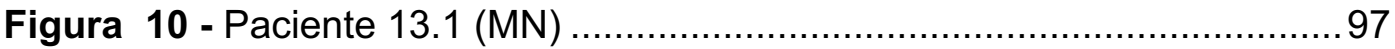

Figura 11 - Biópsias musculares do paciente 17.1 (MN) ………………......98

Figura 12 - Pacientes com variantes patogênicas no gene NEB ...................103

Figura 13 - Paciente com variante patogênica no gene CHRNE ..................105

Figura 14 - Pacientes com variantes patogênicas no gene TPM3 ….............108

Figura 15 - Pacientes com variantes patogênicas no gene $R Y R 1$ …............ 111

Figura 16 - Paciente com $\mathrm{MCl}$ e mutação no gene TTN .................................113

Figura 17 - Pacientes com MCl e mutação no gene $\mathrm{MYH7}$.........................117

Figura 18 - RM de músculo imagem pesada em T1 dos pacientes 38.1 e 39.1

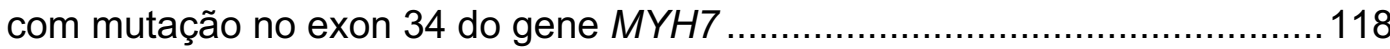

Figura 19 - RM de músculo imagem pesada em T1 do paciente $39.2 \mathrm{com}$ mutação em mosaico no exon 34 do gene $M Y H 7$ 


\section{LISTA DE TABELAS}

Tabela 1 - Genes relacionados a MN e correlação fenotípica.

Tabela 2 - Sequência de oligonucleotídeos para amplificação de regiões codificadoras dos genes ACTA1, TPM3, SEPN1 e MYH7.

Tabela 3 - Principais características clínicas dos pacientes com MN (Pacientes 1.1 até 10.1).

Tabela 4 - Principais características clínicas dos pacientes com MN (Pacientes 11.1 até 20.1)

Tabela 5 - Exames complementares dos pacientes com MN. 65

Tabela 6 - Principais características clínicas dos pacientes com MCl (Pacientes de 21.1 até 30.1)

Tabela 7 - Principais características clínicas dos pacientes com $\mathrm{MCl}$ (Pacientes de 31.1 até 40.1)

Tabela 8 - Exames complementares dos pacientes com MC 82

Tabela 9 - Resultados do estudo genético dos pacientes com $\mathrm{MN}$ e $\mathrm{MCl}$ 90 


\section{RESUMO}

Moreno CAM. Estudo clínico, histológico e molecular na miopatia congênita nemalínica e na miopatia congênita com alterações mínimas [tese]. São Paulo: Faculdade de Medicina, Universidade de São Paulo; 2016.

Introdução: As miopatias congênitas são doenças musculares genéticas caracterizadas por hipotonia e fraqueza muscular de início precoce na infância. Histologicamente são caracterizadas por alterações estruturais no músculo esquelético (corpos nemalínicos, cores ou centralização nuclear), no entanto, existem casos com alterações leves e inespecíficas, alterações mínimas, tais como, desproporção no tamanho das fibras e desarranjo na arquitetura interna das fibras (falhas focais na atividade oxidativa). Quanto ao aspecto molecular, vários genes já foram identificados em associação com os diversos subtipos, porém com grande sobreposição de achados histológicos e clínicos. Objetivo: Caracterização clínica, histológica e molecular de pacientes Brasileiros com miopatia nemalínica e com miopatia congênita com achados histológicos mínimos. Métodos: Avaliação clínica e histológica (revisão dos achados das biopsias musculares) de pacientes com diagnóstico de miopatia congênita nemalínica e com alterações mínimas, provenientes de dois centros de investigação em doenças neuromusculares da cidade de São Paulo (HC-FMUSP e UNIFESP). O estudo molecular foi realizado através de sequenciamento Sanger para os genes ACTA1, TPM3, MYH7 e SEPN1 e/ou sequenciamento de nova geração para painel de genes musculares e/ou exoma. Resultados: Foram avaliados 23 pacientes com miopatia nemalínica (20 famílias) e 22 pacientes com alterações mínimas (20 famílias). O diagnóstico molecular foi concluído em sete famílias com miopatia nemalínica, sendo quatro com variantes missense, em heterozigose, no gene ACTA1 já associadas previamente a miopatia nemalínica, e três famílias, com variantes não conhecidas, em heterozigose, no gene $N E B$ com alta predição de patogenicidade. Na coorte de miopatias congênitas com alterações mínimas o diagnóstico molecular foi concluído em nove famílias, sendo uma com variante conhecida no gene CHRNE, descrita em miastenia congênita; duas famílias com variantes no gene TPM3, sendo uma inédita, em homozigose, e outra, em heterozigose, já conhecida; duas famílias com variantes novas, em heterozigose, no RYR1, uma no gene TTN e três 
XXII

famílias com variantes já conhecidas no gene no MYH7 com fenótipo de miopatia distal de Laing. A despeito da realização de sequenciamento de exoma, sete famílias ainda permanecem sem gene candidato. Conclusões: Os achados clínicos, histológicos e moleculares dos pacientes da coorte de miopatia nemalínica seguem aos padrões descritos da literatura. O estudo dos pacientes com miopatia congênita com alterações mínimas se revelou complexo e variável, tanto no fenótipo quanto no genótipo. As mutações novas no gene $N E B, R Y R 1$, TTN, TPM3 e MYH7 confirmam a importância e patogenicidade destes genes nas miopatias congênitas e ampliam o seu espectro de alterações. Diante da quantidade de genes candidatos e do tamanho de alguns genes envolvidos com essas miopatias, técnicas de sequenciamento de nova geração são de grande valor.

Descritores: Descritores: miopatias congênitas estruturais; miopatias congênitas estruturais/diagnóstico; miopatias congênitas estruturais/histologia; miopatias da nemalina; músculos/biópsia; doenças musculares; estudo clínico. 


\begin{abstract}
Moreno CAM. A clinical, histological and molecular study of nemaline congenital myopathy and congenital myopathy with minimal changes
\end{abstract}

[thesis]. São Paulo: “Faculdade de Medicina, Universidade de São Paulo;2016.

Introduction: Congenital myopathy are a group of genetic muscle diseases characterized by hypotonia and weakness in early childhood. They are characterized by structural abnormalities in muscle biopsy (nemaline bodies, central-cores or nuclear centralization). However, it can present within mild and unspecific findings like fiber type disproportion and abnormalities on oxidative staining (minimal changes). Regarding the molecular aspects, there are many genes associated with the congenital myopathies with an important overlapping between the histological and phenotypical findings. Objectives: Clinical, histological and molecular characterization of Brazilian patients with nemaline myopathy and congenital myopathy with minimal changes. Methods: Clinical and histological evaluation (review of muscle biopsy) of patients with nemaline myopathy and congenital myopathy with minimal changes from two centers of neuromuscular diseases (HC-FMUSP e UNIFESP). The molecular study was performed using Sanger sequencing for ACTA1, TPM3, SEPN1 and MYH7 genes and/or neuromuscular panel and/or exome. Results: Twenty-three patients with nemaline myopathy (20 families) and 22 patients with congenital myopathy with minimal changes (20 families) were evaluated. The molecular diagnose were concluded in seven families with nemaline myopathy, with four families having missense, heterozygous and pathogenic ACTA1 variants and three families having unknown heterozygous and pathogenic variants in NEB gene. In the congenital myopathy with minimal findings group, the diagnose was concluded in 9 families. One presenting with a pathogenic variant in $C H R N E$ gene previously described in congenital myasthenia, two families with pathogenic variants in TPM3, one novel homozygous and one heterozygous previously reported. Two families presented with novel and pathogenic RYR1 variants, one with novel and pathogenic TTN variants and 3 families presented with heterozygous variants in MYH7 myopathy with Laing distal myopathy phenotype. Despite the NGS realization, 7 families remain without a gene candidate. Conclusions: The clinical, histological and molecular findings of nemaline 
myopathy cohort follow the literature pattern. In contrast, the study for minimal change patients appear complex and variable, either on phenotype or on genotype. The new gene mutations for NEB, RYR1, TTN, TPM3 and MYH7 reinforce relevance and pathogenicity of these genes in the congenital myopathies and expand the mutation spectrum. In light of diversity of candidate genes and the size of some genes involved with these myopathies, next generation sequencing techniques have been proved essential.

Descriptors: myopathies, structural, congenital; myopathies, structural, congenital/diagnosis; myopathies, structural, congenital/histology; myopathies, nemaline; muscles/biopsy; muscular diseases; clinical study. 


\section{INTRODUÇÃO}

Miopatias congênitas (MC) são doenças neuromusculares genéticas, caracterizadas por hipotonia e fraqueza muscular precoces na infância. Hiporreflexia, hipotrofia, achados dismórficos como pectus carinatum, escoliose, deformidades nos pés, palato arqueado e face alongada estão normalmente presentes. O diagnóstico é realizado através do quadro clínico somado a alterações estruturais características na biópsia muscular.

A classificação é baseada nas alterações histológicas predominantes na biópsia muscular e estratifica as MC em quatro grupos: (1) miopatia com bastões nemalínicos (agregados proteicos), nas quais são observados acúmulos de proteínas oriundas do disco Z, sendo a miopatia nemalínica (MN) o principal integrante deste grupo; (2) miopatia com centralização nuclear, na qual se observa núcleos em posições anormais e normalmente centrais; (3) miopatia com presença de cores, que são áreas destituídas de atividade oxidativa no interior da fibra muscular, visualizadas em colorações histoquímicas específicas. Esta falha é bem delimitada, podendo ser única e central como na miopatia central-core, única e periférica como na miopatia com core excêntrico, ou múltiplas e difusas como na miopatia multi/minecore; e (4) miopatia com variação no tamanho das fibras, na qual a presença de importante aumento da variabilidade no tamanho entre os tipos de fibras ocorre na ausência de outros achados estruturais característicos. O achado predominante é atrofia e predomínio de fibras tipo 1. 
Alguns pacientes com quadro clínico de MC possuem achados leves e inespecíficos na biópsia muscular como atrofia de fibras tipo 2, predomínio e atrofia de fibras tipo 1, variabilidade do tamanho das fibras, falhas focais de atividade oxidativa, aumento do tecido conjuntivo e aumento do número de centralizações nucleares. Nos referimos a estes pacientes como tendo miopatia congênita com achados mínimos ou achados leves e inespecíficos (miopatia congênita inespecífica - $\mathrm{MCl}$ ) na biópsia muscular.

Os genes que causam as MC codificam componentes do aparelho contrátil do músculo esquelético (sarcômero) observado principalmente nas miopatias com agregrados proteicos e desproporção de fibras, e também proteínas que atuam no transporte e sinalização de cálcio, comprometendo desta forma a contração muscular, como observado nos subtipos com centralização nuclear e cores. O diagnóstico molecular dos pacientes com MC é de grande importância para a classificação do paciente, para uma melhor compreensão dos mecanismos fisiopatogênicos envolvidos e também para a elaboração de estratégias terapêuticas.

Existe uma grande sobreposição entre achados clínicos e moleculares. Um mesmo gene pode estar relacionado a mais de um fenótipo, assim como, um mesmo fenótipo pode estar associado a vários genes. Uma caracterização adequada do quadro clínico, histológico e de imagem do paciente pode oferecer pistas diagnósticas importantes para o seu estudo molecular sugerindo um gene candidato e orientando quanto a melhor técnica de sequenciamento a ser utilizada. O estudo genético pode ser realizado através de técnicas convencionais (Sanger) ou através de sequenciamentos de nova geração (NGS). Nos sequenciamentos convencionais, o estudo de cada gene é realizado 
separadamente. Já os NGS permitem o estudo de vários genes em uma mesma plataforma. A grande dificuldade destas técnicas de ampla cobertura, consiste na interpretação dos dados e na identificação das variantes patogênicas.

Neste trabalho vamos estudar o quadro clínico e histológico de pacientes com miopatia congênita relacionada com prováveis alterações em proteínas sarcoméricas, assim sendo, as miopatias congênitas com agregados proteicos e achados inespecíficos na biópsia muscular; sequenciar os genes ACTA1, TPM3, SEPN1 e MYH7 analisando a frequência de mutação destes genes nos grupos de pacientes selecionados e também, analisar a utilização e a cobertura de NGS nestes pacientes. 


\section{REVISÃO DE BIBLIOGRAFIA}

\subsection{Miopatias congênitas}

MC são doenças musculares hereditárias que se manifestam com hipotonia e fraqueza muscular de início precoce na infância. São classificadas de acordo com alterações estruturais específicas na biópsia muscular. De acordo com esses achados, podem ser divididas em 4 grandes grupos: (1) miopatias com acúmulos proteicos (bastões nemalínicos); (2) miopatias com cores; (3) miopatias com núcleo central; e (4) miopatias com variação no tamanho das fibras (North, 2011). Achados morfológicos mistos como cores e bastões ou cores e núcleos centrais já foram descritos (Olive et al., 2010). A maior parte das miopatias congênitas são diagnosticadas pela microscopia óptica. As reações imunohistoquímicas são raramente necessárias e a microscopia eletrônica pode auxiliar em casos que geram dúvidas ou naqueles com suspeita clínica nos quais os achados estruturais não foram identificados (North, 2011).

O espectro clínico das MC é amplo e pode variar desde quadros graves com acinesia fetal, diminuição dos movimentos intrauterinos e insuficiência respiratória grave no período neonatal, a quadros leves com fraqueza proximal de início tardio e inaptidão para atividade física. As principais manifestações clínicas são: fraqueza muscular de início no período neonatal, hipotonia neonatal, reflexos tendinosos profundos reduzidos ou abolidos e atraso na aquisição dos marcos motores sem comprometimento cognitivo. Outros sintomas frequentes são: dificuldade para sugar, dificuldade para engolir, infecções respiratórias de repetição, achados dismórficos faciais (palato arqueado, dolicocefalia e face alongada), deformidades osteoesqueléticas 
(escoliose, contraturas, pectus carinatum) e deformidades nos pés. Oftalmoparesia, fraqueza facial e ptose palpebral ocorrem em algumas formas clínicas e quando presentes representam importantes pistas diagnósticas. A fraqueza muscular pode se apresentar em diversos padrões. As formas com fraqueza generalizada ou de predomínio proximal são as mais características, no entanto, quadros predominantemente axiais ou distais podem ser observados (Colombo et al., 2015; Nance et al., 2012; North, 2011).

Exames complementares auxiliam no diagnóstico diferencial. Os níveis séricos da enzima creatinofosfoquinase (CPK) encontram-se normais ou com discreto aumento, diferente dos valores aumentados encontrados nos pacientes com distrofia muscular congênita. A eletroneuromiografia (ENMG) pode sugerir miopatia ou ser normal, com estudos de condução nervosa normais. Este exame é importante no diagnóstico diferencial com doença do neurôno motor e neuropatia periférica (North, 2011).

Do ponto de vista molecular, vários genes já foram implicados na etiopatogenia das MC. Existe uma grande variabilidade fenotípica e genotípica neste grupo de pacientes. Um mesmo gene pode determinar vários fenótipos, como por exemplo o gene da tropomiosina 3 (TPM3) que está associada a MN (Durling et al., 2002), miopatia com cap (Ohlsson et al., 2009) e DCTF (N. F. Clarke et al., 2008). Além disso, um mesmo fenótipo pode ser causado por diferentes genes. A miopatia mine-core, por exemplo, pode ser causada por mutações no gene RYR1, SEPN1 e MYH7 (Jungbluth et al., 2011).

Vários mecanismos fisiopatogênicos já foram propostos. Com a descoberta de novos genes e a expansão de seus respectivos fenótipos, estes 
mecanismos estão ficando cada vez mais complexos. Os principais substratos envolvidos são proteínas do sarcômero, proteínas envolvidas na sinalização do íon cálcio na membrana, responsáveis pelo mecanismo de contração muscular (North, 2011), e também, proteínas envolvidas na ubiquitinização (Sambuughin et al., 2010).

Apesar das miopatias congênitas serem classificadas com base nas suas alterações histológicas, existe uma tendência atual em classificar o paciente de acordo com o sua alteração molecular como por exemplo: miopatias relacionadas com ACTA1- actinopatias (K. J. Nowak et al., 2013); miopatias relacionadas com SEPN1 - selenopatias (Schara et al., 2008).

Abaixo uma descrição mais abrangente dos subtipos de miopatia congênita. 


\subsubsection{Miopatia Nemalínica}

Várias proteínas podem se acumular no interior da fibra muscular. A maioria dos agregados proteicos são formados a partir proteínas oriundas do sarcômero. A forma mais comum de miopatia com agregados proteicos é a miopatia nemalínica, na qual os agregados são formados a partir do filamento fino e possuem o formato de bastões (bastões nemalínicos). Outras formas de miopatia com acúmulo de proteínas do filamento fino são a miopatia com "cap", miopatia com corpos zebróides e miopatia com agregados de actina. Miopatias com acúmulo de proteínas oriundas do filamento espesso são mais raras e a miopatia com corpos hialinos é o seu subtipo mais comum (Agrawal et al., 2004; North, 2011).

O nome nemalínico é proveniente do prefixo grego nema que significa "fio". Esta nomenclatura foi utilizada pela primeira vez na descrição de miopatia em 1963 por Shy et al, que relatou uma criança hipotônica do sexo feminino com a presença de estruturas em forma de bastões de tamanhos variáveis na biópsia muscular (Shy et al., 1963).

Atualmente MN é um dos subtipos mais frequentes de MC. Corresponde a cerca de $17 \%$ dos casos e afeta 1:50.000 indivíduos (Romero et al., 2013). Além das formas congênitas hereditárias clássicas, o quadro pode ter início na idade adulta, conhecido como miopatia nemalínica de inicio tardio (slow onset nemaline myopathy - SLONM). A maior parte destes casos permanece sem confirmação genética, o que sugere uma etiologia diferente daquela encontrada nas formas congênitas (Chahin et al., 2005). 
Como já mencionado acima, a MN caracteriza-se histologicamente pela presença de estruturas eosinofílicas na coloração Tricrômico de Gomori (GO) em formato de bastões na fibra muscular. Os bastões são polímeros compostos de materiais de linha $Z$ como teletonina, miotilina, filamina, miozenina, miopaladina e principalmente alfa-actina. A sua localização e quantidade no interior da fibra muscular são variáveis e não se correlacionam com a clínica que o paciente apresenta. Quanto a sua distribuição, podem estar aglomerados em regiões subsarcolemais, inclusive com a formação de massas citoplasmáticas, estar distribuídos difusamente pelo citoplasma da fibra ou até mesmo dentro do núcleo. Com relação a quantidade, podem estar presentes em 100\% das fibras ou apenas em uma pequena população de fibras ou ainda se restringir a um tipo de fibra (North et al., 1997). Em alguns casos é necessário mais de um sítio de biópsia para a visualização dos agregados. A microscopia eletrônica é de grande utilidade nos casos inconclusivos, principalmente nos casos em que os bastões são muito pequenos ou intranucleares. Serão visualizadas estruturas elétrondensas ovóides ou em formato de bastões, determinado pelo plano de secção, ou paralelas ao eixo longo do sarcômero. Há um caso descrito em que não foram encontrados bastões na biópsia muscular e o diagnóstico foi feito de acordo com o padrão de acometimento muscular nos exames de imagem e teste molecular (Castiglioni et al., 2014).

Assim como outras miopatias congênitas, associados aos achados estruturais predominantes, outros achados na biópsia muscular são relatados com frequência como: (1) variação no tamanho das fibras, (2) desproporção de tipo de fibras e (3) predominância de fibras tipo 1 (Ilkovski et al., 2001). Mais raramente podem ainda ser encontrados achados como: aumento de tecido 
conjuntivo, internalização nuclear e necrose/regeneração de fibras musculares (Ryan et al., 2003).

Os bastões nemalínicos podem ser encontrados em outras situações além de MN. Podem estar presentes na junção neurotendínea, em idosos e em músculos extraoculares sem qualquer substrato fisiopatológico, bem como em outras doenças como na miopatia core-bastões (Wallgren-Pettersson et al., 2011).

O fenótipo dos pacientes com MN também é bastante variável. O espectro de acometimento abrande desde formas neonatais graves com acinesia fetal e insuficiência respiratória até formas leves de início na infância ou no adulto. A fraqueza muscular, na maioria dos casos, é simétrica, generalizada, com predomínio proximal e de músculos flexores do pescoço (Nance et al., 2012).

Quanto às formas clínicas, o ENMC (European Neuromuscular Center) através da realização de consórcios internacionais com especialistas de diversos paises (International Consortium on Nemaline Myopathy) divide a MN em 6 categorias com base na forma típica, sendo elas: (1) forma congênita grave pacientes possuem movimentação espontânea pobre, acinesia fetal, dificuldade de deglutir e necessitam de suporte respiratório logo ao nascer. Podem apresentar retrações tendíneas e fraturas; (2) forma congênita intermediária pacientes apresentam movimentação espontânea e movimentos respiratórios logo ao nascer mas evoluem precocemente com necessidade de suporte ventilatório. As aquisições motoras são pobres e os pacientes não chegam a adquirir marcha; (3) forma congênita típica - pacientes apresentam atraso na aquisição dos marcos motores, hipotonia neonatal e fraqueza muscular em distribuição típica com lenta progressão; (4) miopatia nemalínica leve com início 
na infância -pacientes não apresentam atraso dos marcos motores. Apresentam fraqueza proximal insidiosa e intolerância ao exercício; (5) miopatia nemalínica de início no adulto; (6) outras formas de miopatia nemalínica, sendo a $\mathrm{MN}$ da população Amish, a principal representante (Wallgren-Pettersson et al., 2011).

O acometimento da musculatura respiratória é frequente e precoce, tendendo a ser desproporcional ao grau de fraqueza apendicular. A função respiratória deve ser monitorada rigorosamente, portanto, mesmo em pacientes com fenótipos aparentemente mais leves. Apesar de casos com cardiomiopatia dilatada já terem sido relatados na literatura, a contratilidade cardíaca não é frequentemente afetada. Avaliações cardíacas são realizadas logo após o diagnóstico e podem ser repetidas após longos intervalos ou na suspeita clínica de cardiopatia (Colombo et al., 2015; Wallgren-Pettersson et al., 2011).

A MN se manifesta em um amplo espectro genotípico. Até o momento, dez genes foram associados ao espectro das MN (tabela 1): TPM3/ TPM2 tropomiosinas 2 e 3, NEB - nebulina, ACTA1 - alfa actina esquelética, TNNT1 troponina T lenta, CFL2 - cofilina músculo específica, KLHL40 - membro 40 da família Kelch, KLHL41 - membro 41 da família Kelch, KBTBD13 - membro da família BTB/Kelch, LDM3 - leiomodina 3 e miosina XVIIIB (MYO18B) (Laing et al., 2009; Pelin et al., 1999; Romero et al., 2013; Tan et al., 1999; Yuen et al., 2015). Todas as formas caracterizadas molecularmente são autossômicas com padrão de herança recessivo ou dominante. A maioria dos genes codificam proteínas do filamento fino do sarcômero. A exceção do gene TNNT1, que está associado a um distinto quadro de miopatia nemalínica descrito inicialmente na população Amish, a distribuição em frequência dos outros genes parece ser homogênea ao redor do mundo. A causa mais comum de $\mathrm{MN}$ com padrão de 
herança autossômica recessiva são mutações no gene $N E B$, enquanto para as formas dominantes, o gene ACTA1 é o predominante (Romero et al., 2013).

A seguir discutiremos isoladamente os genes envolvidos com a $\mathrm{MN}$ em ordem decrescente de frequência.

Tabela 1 - Genes relacionados a MN e correlação fenotípica.

\begin{tabular}{|c|c|c|c|c|c|c|}
\hline Gene & $\begin{array}{l}\text { Fenótipo } \\
\text { (OMIM) }\end{array}$ & $\begin{array}{l}\text { Número } \\
\text { MIM }\end{array}$ & Proteína & Herança & Fenótipo & $\begin{array}{l}\text { Proporção } \\
\text { de pacientes }\end{array}$ \\
\hline TPM3 & NEM1 & 609284 & $\begin{array}{c}\text { alfatropomiosina } \\
\text { lenta }\end{array}$ & AD/AR & $\begin{array}{l}\text { Cong grave (AR); } \\
\text { cong interm e início } \\
\text { na infância (AD) }\end{array}$ & $<2 \%$ \\
\hline NEB & NEM2 & 256030 & Nebulina & AR & $\begin{array}{c}\text { forma típica } \\
\text { (maioria); outros } \\
\text { fenótipos (menos } \\
\text { comum) }\end{array}$ & $>50 \%$ \\
\hline ACTA1 & NEM3 & 161800 & $\begin{array}{l}\text { Alfa-actina } \\
\text { esquelética }\end{array}$ & $\mathrm{AD} / \mathrm{AR}$ & $\begin{array}{c}\text { Variável / cong } \\
\text { grave }\end{array}$ & $15-25 \%$ \\
\hline TPM2 & NEM4 & 609285 & betatropomiosina & $A D$ & Forma típica & $<2 \%$ \\
\hline TNNT1 & NEM5 & 605355 & Troponina T lenta & AR & $\begin{array}{l}\text { Miopatia nemalínica } \\
\text { Amish }\end{array}$ & $\begin{array}{l}\text { População } \\
\text { Amish }\end{array}$ \\
\hline KBTBD13 & NEM6 & 609273 & $\begin{array}{c}\text { Repetição Kelch } \\
\text { e domínio BTB e } \\
\text { proteína } 13\end{array}$ & $A D$ & $\begin{array}{l}\text { Início na infância, } \\
\text { lentidão nos } \\
\text { movimentos }\end{array}$ & desconhecida \\
\hline CFL2 & NEM7 & 610687 & Cofilina 2 & AR & Congênita típica & rara \\
\hline$K L H L 40$ & NEM8 & 615348 & $\begin{array}{c}\text { Membro } 40 \\
\text { família Kelch }\end{array}$ & AR & Cong grave & $<5 \%$ \\
\hline$K L H L 41$ & NEM9 & 615731 & $\begin{array}{c}\text { Membro } 41 \\
\text { família Kelch }\end{array}$ & AR & $\begin{array}{l}\text { Frameshift - cong. } \\
\text { grave } \\
\text { Misscence - cong } \\
\text { infantil tardia }\end{array}$ & rara \\
\hline LMOD3 & NEM10 & 616165 & Leiomodina & AR & Cong grave & rara \\
\hline MYO18B & & 616549 & Miosina 18B & $A R$ & $\begin{array}{l}\text { Síndrome Klippel- } \\
\text { Feil com miopatia } \\
\text { nemalínica e } \\
\text { dismorfismos faciais }\end{array}$ & rara \\
\hline
\end{tabular}

NEM: sigla do OMIM para miopatia nemalínica. Cong.: Congênita. Interm.: intermediário. AD: Autossômica dominante. AR: Autossômica recessiva. 


\subsubsection{Gene da Nebulina (NEM2)}

Nebulina é uma proteína filamentosa gigante (600 - 900-KDa) codificada pelo gene $N E B$. Faz parte da constituição do filamento fino e atua na estabilização do filamento da actina, na regulação da contração muscular e na homeostase do cálcio. A expressão desta proteína no músculo se correlaciona diretamente com a gravidade da doença, de tal modo que quanto menor a quantidade da proteína detectável pior o prognóstico do paciente (Labeit et al., 2011).

O gene NEB possui 183 exons. Por ser um gene muito grande e não apresentar hot spots, o seu sequenciamento através de técnicas convencionais é muito difícil (Pelin et al., 2008). A maioria das mutações são pequenas deleções, duplicações ou substituições de base causando códons de parada prematuros ou splicing anormal. Todas as mutações são recessivas podendo ocorrer em homozigose ou heterozigose composta (Pelin et al., 2008).

Mutações neste gene são associadas a MN, classificadas geneticamente como NEM2 (segundo gene a ser descoberto). Este gene é responsável pela maioria dos casos com padrão de herança recessivo, podendo acometer mais de $50 \%$ destes pacientes. A forma clínica de MN mais associada a este gene é a forma típica, mas se associa também a formas mais graves (Pelin et al., 1999). Os pacientes com NEM2 apresentam fraqueza de predomínio proximal mais pronunciada na musculatura axial e em cinturas. Evoluem com acometimento distal principalmente em dorsiflexores dos pés. Os extensores dos joelhos tendem a ser melhores que os flexores. A incapacidade de flexão do pescoço quando em posição supina e o envolvimento facial, bulbar e de língua também são achados frequentemente observados. Estudos de imagem em pacientes 
com NEM2 mostram um acometimento predominantemente distal em compartimento anterior com musculatura da coxa relativamente poupada (Wallgren-Pettersson et al., 2004).

Existem vários fenótipos de miopatia com envolvimento predominantemente distal associados a mutações no gene NEB sendo eles: (1) miopatia distal sem bastões nemalínicos, (2) pacientes com NEM2 e envolvimento predominantemente distal (Lehtokari et al., 2011) e (3) miopatia distal com presença de cores e bastões (Romero et al., 2009).

Quanto aos aspectos histológicos envolvendo MN causadas por mutações no gene NEB as principais são: (1) bastões em ambos os tipos de fibras e (2) associação entre cores e bastões (North et al., 2014).

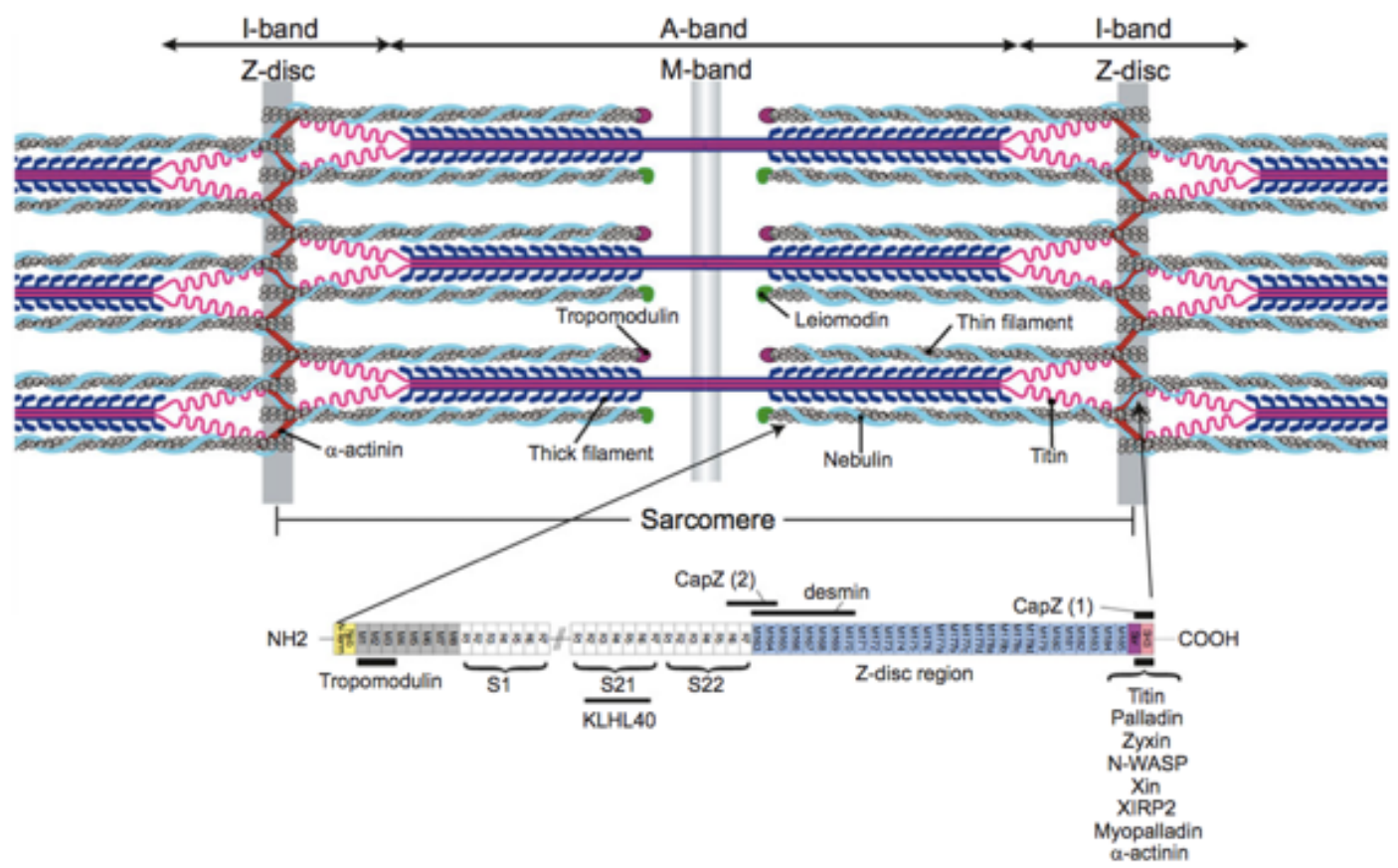

Figura 1 - Estrutura esquemática do sarcômero: localização da proteína nebulina e seus sítios de ligação com as proteínas tropomodulina, KLHL40, desmina, titina, e alfa-actina. Essas ligações sugerem a importância desta proteína gigante na manutenção da estrutura e estabilização do sarcômero (Chu et al., 2016). 


\subsubsection{Gene da Alfa-actina (NEM3)}

As actinas formam uma família constituída por 6 isoformas que compartilham mais de $90 \%$ de similaridade estrutural ao nível de aminoácidos. Estas proteínas estão envolvidas em várias funções celulares como morfologia e motilidade celular.

Alfa-actina músculo esquelética é a principal isoforma de actina do músculo esquelético adulto. Esta proteína é a estrutura central do filamento fino do sarcômero e interage com diversas proteínas envolvidas na contração muscular. A alfa-actina cardíaca é a principal isoforma expressa no músculo cardíaco e a principal isoforma expressa no músculo esquelético durante a gestação, diminuindo sua expressão a partir do terceiro trimestre. A alfa-actina esquelética e a alfa-actina cardíaca são estruturalmente semelhantes e diferem entre si por apenas 4 resíduos em sua proteína matura (Sheterline, et al., 1998).

O gene ACTA1 codifica a alfa-actina esquelética. Está localizado na região $1 q 42,13$, é formado por sete exons dos quais seis são codificantes. 0 RNAm codifica uma proteína de 377 aminoácidos que se modula em um monômero globular (G-actina) com peso de 42kDa que será polimerizada em Factina, componente primário do filamento fino (Laing et al., 2009).

As actinas são proteínas muito conservadas, portanto a maioria das trocas de aminoácidos resultantes de mutações missenses são causadoras de doenças (Laing et al., 2009).

Mutações no gene ACTA1 podem resultar em vários subtipos de miopatias: (1) miopatia nemalinica (NEM3) (D. Nowak et al., 1999); (2) miopatia com bastão intranuclear(Goebel et al., 1997); (3) miopatia com agregados filamentosos de actina (Sparrow et al., 2003); (4) desproporção congênita de 
tipo de fibras (DCTF) (Laing et al., 2004), (5) miopatia com áreas core-like (Kaindl et al., 2004), (6) miopatia cap (Hung et al., 2010) , (7) miopatia com corpos zebroides (Sewry et al., 2015) e mais recentemente, (8) miopatia escapuloperoneal progressiva (Zukosky et al., 2015). A mistura de todos estes achados pode ser encontrada em um único paciente.

Com relação a $\mathrm{MN}$, até um quarto dos casos das formas típicas são causados por mutações neste gene, sendo ainda mais frequente dentro do grupo das formas clínicas mais graves. O tipo de mutação não está relacionado diretamente com a gravidade do quadro clínico (Laing et al., 2009).

O quadro clínico dos pacientes com NEM3 é frequentemente grave, cursando com hipotonia neonatal, acinesia fetal e insuficiência respiratória. Formas intermediárias, leves e típicas também são comuns(Feng et al., 2009). Os pacientes apresentam envolvimento preferencial dos músculos extensores do joelho quando comparados aos flexores preservando os dorsiflexores dos pés, diferente dos pacientes com NEM2 (Oishi et al., 1998).

A maior parte das mutações identificadas são mutações dominantes de novo, mutações em heterozigose que não estão presentes nos pais. Mosaicismo é raro e já foi documentado em algumas famílias. Mutações recessivas se comportam como mutações nulas causando fenótipos graves, no entanto formas moderadas e leves já foram relatadas. Provavelmente este fato está relacionado a expressão compensatória da alfa-actina cardíaca (K. J. Nowak et al., 2007).

Apesar dos mecanismos fisiopatogênicos ainda não estarem completamente desvendados, a posição da mutação influencia diretamento no fenótipo. O conhecimento da estrutura da proteína é fundamental para se compreender os diferentes fenótipos. As mutações que causam miopatia com 
agregados de actina estão localizadas nos subdomínios um e três próximos a região central (hinge) e parecem comprometer a formação da ligação entre os nucleotídeos. Já as mutações que causam MN com bastões intranucleares estão normalmente localizadas entre os resíduos 139 e 165, também próximos a região central (Sparrow et al., 2003).

A análise imunohistoquímica em pacientes com NEM3 é complexa. Inicialmente llkovvski et al, não observou nenhum aumento compensatório na alfaactina cardíaca em mutações no ACTA1. Este achado foi confirmado em casos com mutações dominantes por Pankaj et al, 2004, entretanto, em um paciente com combinação de uma mutação missence com deleção/frameshift foi observado um aumento na expressão da alfaactina cardíaca (Agrawal et al., 2004).

Quanto aos aspectos histológicos envolvendo MN causadas por mutações no gene ACTA1, as principais são: (1) bastões em ambos os tipos de fibras; (2) acúmulo de actina visualizadas como áreas com depósito proteico na coloração HE ou GO que não possuem atividade na ATPase; (3) bastões intranucleares; (4) corpos zebroides e (5) desproporção de tipo de fibras (North et al., 2014).

\subsubsection{Genes das tropomiosinas (NEM1 e 4)}

Tropomiosinas (Tm) são proteínas expressas em células eucarióticas acopladas na actina que atuam na contração muscular estabilizando a actina e regulando interação actina/miosina ao limitar os sítios ligadores de miosina ao longo do filamento de atina (Gunning et al., 2005). Participam da ligação da miosina com a actina para que ocorra a contração muscular. Os filamentos finos 
do músculo estriado contêm principalmente actina, tropomiosina e troponina e são ativados através da ligação com cálcio promovendo assim a ligação com a troponina e miosina. Foram inicialmente isoladas como sendo a principal proteína miofibrilar do músculo esquelético e chamadas de $\mathrm{Tm}$ pela grande semelhança entre sua composição e suas propriedades físicas com a miosina muscular (Bailey, 1946).

As Tm são produzidas por quatro genes (TPM1-4), sendo os mais importantes o TPM1, que codifica a alfatropomiosina rápida; TPM2, que codifica a betatropomiosina (Tm2) e TPM3 que codifica a alfatropomiosna lenta (Tm3), uma isoforma músculo-específica expressa nas fibras musculares tipo1 (Gunning et al., 2005).

Mutações nestes três genes foram associadas às seguintes doenças do músculo estriado: MN (TPM2 e TPM3) (Donner et al., 2002), DCTF (TPM2 e TPM3) (DeChene et al., 1993), artrogripose distal (TPM2) (Sung et al., 2003), doença com "cap" (TPM2) e cardiomiopatia com DCTF (TPM1) (Durling et al., 2002).

\subsection{Alfa-tropomiosina lenta (NEM1)}

O gene TPM3 é constituído por 10 exons (Tan et al., 1999). Mutações neste gene já foram descritas em pacientes com MN, DCTF, miopatia com cap e até mesmo em $\mathrm{MCl}$. A presença de desproporção de fibras é um achado comum dentre pacientes com mutações neste gene, no entanto, a sobreposição de achados pode ocorrer como a presença de cap e bastões (Ohlsson et al., 2009). 
O gene TPM3 foi a primeira causa genética estabelecida para a $\mathrm{MN}$, classificada do ponto de vista genético como NEM1. A primeira descrição foi em uma família australiana com uma mutação dominante com fraqueza de predomínio nos membros inferiores (Laing et al., 1995). Subsequentemente, se observou que os achados clínicos nestes pacientes eram variáveis (Tan et al., 1999).

Nos pacientes com MN e mutação TPM3, a desproporção de fibras é variável, com atrofia de fibras tipo 1 e presença de bastões nemalínicos predominantemente em fibras tipo 1. A fraqueza tem predomínio nos membros inferiores (Romero et al., 2013; Wallgren-Pettersson et al., 2011).

Os mecanismos pelos quais mutações neste gene causam doença muscular não foram totalmente elucidados. Em um trabalho com um modelo experimental no qual foi induzida uma mutação, que em humanos causa MN (Met8Arg), foi visto que a mutação compromete a afinidade dos filamentos finos da actina e leva a acúmulo de dímeros. Esta mutação ocasiona uma substituição de um resíduo de arginina por uma metionina em um sítio de ligação da actina próximo ao resíduo $\mathrm{N}$-terminal da Tpm3 de modo a fortalecer a ligação actinatropomiosina (Laing et al., 1995). A relativa lenta progressão da doença é atribuída ao fato da Tpm3 se expressar somente em fibras tipo 1 e ainda de não ser a única tropomiosina expressa. Estudo em 12 famílias turcas com MN recessiva identificou uma mutação fundadora, deleção do primeiro nucleotídeo do último exon, que remove o ultimo nucleotídeo antes do códon de parada causando um efeito de erro de leitura. A proteína que é produzida possui 73 aminoácidos a mais que o normal, resultando em uma proteína não funcional 
pela alteração na sua conformação. Mais estudos são necessários para uma melhor compreensão da sua fisiopatogenia (Lehtokari et al., 2008).

\subsection{Beta-tropomiosina (NEM4)}

Mutações no gene da beta-tropomiosina (TPM2) são uma causa rara de MC com achados clínicos e histológicos varíáveis. Mutações neste gene estão presentes em até $2 \%$ dos pacientes com MN, classificada do ponto de vista genético como NEM4. Os pacientes seguem um padrão de herança autossômico dominante e apresentam-se clinicamente com quadro clínico leve da infância ou típico. Mutações neste gene foram descritas também causando miopatia Cap, DCTF, miopatia com fenótipo "Bethlem-like" e também formas de artrogriposes distais e Síndrome de Escobar associada ou não a MN (Donner et al., 2002). A maior parte dos pacientes apresenta envolvimento da musculatura mastigatória e distal dos membros inferiores. Acomete principalmente o músculo sóleo, poupando a cintura pélvica e escapular. O espectro clínico da doença também é muito variável (Jarraya et al., 2012).

\subsubsection{Troponina T (NEM5)}

O gene TNNT1 se localiza no cromossomo 19q13 e uma mutação nonsense em homozigose neste gene está associada a uma forma distinta de MN (NEM5) descrito apenas na população Amish. Relatos recentes identificaram mutação neste gene em uma família holandesa (van der Pol et al., 2014), em uma família hispânica (Marra et al., 2014) e sete famílias palestinas (Abdulhaq et al., 2016) 
NEM5 se trata de uma forma de MN com características próprias caracterizada por fraqueza muscular progressiva grave de início precoce, deformidade torácica com grave pectus carinatum, atrofia muscular, tremores e contraturas precoces. O curso é rapidamente progressivo levando ao óbito por insuficiência respiratória por volta do segundo ano de vida (Johnston et al., 2000).

Até o momento 4 variantes patogênicas foram identificadas neste gene. A primeira variante (p.E180X), pertence a família Amish, introduz um codon de parada prematura no exon 11 (Marra et al., 2014). Duas variantes foram descritas em heterozigose composta na família holandesa (splice site c.309+1G>A e deleção no exon 14) (van der Pol et al., 2014), e outra variante patogênica nonsense em homozigose (c.323C>G) no exon 9, foi descrita em uma família hispânica (Marra et al., 2014). Recentemente um rearranjo complexo em homozigose (NM_002383), determinando truncagem da proteína, foi identificado em sete famílias palestinas conferindo uma nova variante deste gene (Abdulhaq et al., 2016).

\subsubsection{Cofilina (NEM7)}

Cofilina é uma proteína moduladora da actina e atua regulando dinamicamente esta proteína. Mutações no gene CFL2 (proteína cofilina músculo esquelética específica) são raras, porém já foram descritas em duas famílias consanguíneas (Agrawal et al., 2007). Uma das famílias é composta por duas irmãs afetadas, de origem iraquiana com a presença na biópsia muscular de bastões nemalínicos, degenerações e agregados miofibrilares. Cofilina-2 é expressa no músculo cardíaco, no entanto, apesar dos pacientes 
ainda serem jovens, cardiopatia não foi observada em nenhum dos casos (Ockeloen et al., 2012).

\subsubsection{Família Kelch (NEM 6, 8 e 9)}

As proteínas Kelch são membros de uma superfamília constituídas por diversas proteínas que possuem em comum a repetição de um domínio: kelch (Adams J 2000). Essas proteínas estão relacionadas em vários processos celulares como migração celular, estrutura de citoesqueleto, regulação da morfologia celular, degradação proteica e expressão gênica (Gupta et al., 2013).

A superfamília Kelch é formada por 66 genes, dos quais 63 são codificantes. De acordo com o seu respectivo domínio proteico, ela é classificada em 3 subfamílias:

- KLHL

- KBTBD

- KLHDC

As proteínas Kelch ligam-se a diferentes substratos através dos seus domínios. Mesmo de subfamílias diferentes, alguns domínios podem se apresentar com sequência homóloga e estarem relacionados a fenótipos semelhantes como é o caso da MN. Até o momento, já foram associadas a esta miopatia mutações nos genes dos seguintes membros da família Kelch: KLHL40, KLHL41 e KBTBD13. Isso sugere que domínios homólogos possam regular processos biológicos semelhantes ou compartilhar interações (Dhanoa et al., 2013).

KBTBD13 é um membro da subfamília KBTBD e mutações no gene KBTBD13 estão relacionadas a um fenótipo de MN (NEM6) autossômica 
dominante com a presença de bastões e cores na biópsia e predominância e hipertrofia de fibras tipo1. Os pacientes apresentam intolerância ao exercício, alteração de marcha e fraqueza muscular progressiva. Um dado clínico que chama atenção nestes pacientes é que são lentos, não conseguem correr e tem uma dificuldade em realizar correções posturais. A fraqueza muscular é lentamente progressiva, com predomínio em musculatura cervical e proximal, poupando musculatura facial (Gommans et al., 2002).

Mutações no gene KLHL40 foram associadas a um fenótipo grave de MN. Mutações recessivas são associadas a acinesia fetal, diminuição da movimentação intrauterina, insuficiência respiratória, dificuldades de sugar, disfagia, retrações tendíneas, fraturas e achados dismórficos. Oftalmoparesia é encontrada em $17 \%$ destes pacientes, podendo ser uma pista diagnóstica, já que não é comum em outros grupos de MN. As mutações podem se localizar em exons que codificam todos os domínios, sendo a maioria delas nas repetições Kelch. Uma mutação fundadora foi descrita em pacientes japoneses, turcos e curdos (Ravenscroft, Miyatake, et al., 2013). Mutações neste gene podem se associar a um fenótipo mais leve. Seferian (2016) relatou um caso de uma paciente com MN apresentando hipotonia neonatal, dificuldade de sugar, atraso motor e fatigabilidade e mutação detectada no gene $K L H L 40$ (Seferian et al., 2016).

Os mecanismos fisiopatogênicos ainda não estão claros, mas sabe-se que a proteína KIhl40 interage com o complexo CUL3 ubiquitinaligase com significado funcional indeterminado. Um trabalho recente evidenciou relação com o myoD, que é um importante fator na diferenciação muscular (Bowlin et al., 2013) 
Mutações no gene $K L H L 41$ foram associadas a uma forma recessiva de MN com uma certa correlação genótipo/fenótipo. Mutações que truncam a proteína, como no caso das mutações frameshift, se associam a um fenótipo grave com acinesia fetal, artrogripose, luxação de quadril e joelhos e morte prematura. Mutações missenses levam a uma forma leve ou intermediária com comprometimento de funções motoras, mas com melhora da sobrevida (Gupta et al., 2013).

Estudos funcionais em zebrafish mostraram que a perda da proteína KIhl41 resulta em diminuição da função motora e desorganização miofibrilar com formação de corpos nemalínicos (Gupta et al., 2013).

\subsubsection{Leiomodina 3 (NEM10)}

O gene $L M O D 3$ entrou recentemente na lista de genes causadores de MN. As leiomodinas, proteínas da família das tropomodulinas, são codificadas por três genes: $L M O D 1, L M O D 2$ e $L M O D 3$. A maioria das mutações do gene LMOD3 resultam em perda completa da expressão da proteína leiomodina-3. Esta proteína é expressa no tecido muscular esquelético e muscular cardíaco desde a diferenciação do mioblasto até a 14 semana de gestação. Os mecanismos envolvidos na fisiopatogenia da MN ainda não estão claros, mas a estrutura do filamento fino é alterada em pacientes com a mutação. Yuen (2015) descreveu 21 indívíduos de 14 famílias com diagnóstico de MN com mutações em heterozigose composta e homozigose consistente com padrão de herança autossômica recessiva. Todas as variantes descritas até o momento são nonsense ou frameshift e estão dispostas ao longo de todo o gene. Estudos com Western Blotting no tecido de pacientes com mutação confirmada, mostraram 
ausência da proteína em praticamente todos os pacientes, exceto em um paciente, no qual a proteína foi detectada em níveis reduzidos (Tian et al., 2015; Yuen et al., 2015).

Os pacientes apresentam a forma grave de apresentação em 90\% dos casos, com graus variados de diminuição da movimentação fetal, polidrâminio, prematuridade e retrações articulares. Todos os pacientes apresentaram ao nascer hipotonia, fraqueza muscular, insuficiência respiratória, dificuldade alimentar e fraqueza bulbar. Em alguns casos foi observado oftalmoplegia. Os achados histológicos na biópsia muscular são bastante peculiares. Na microscopia óptica, foram vistos corpos nemalínicos, atrofia de fibras musculares e aumento de tecido conjuntivo, e na microscopia eletrônica os corpos nemalínicos apareceram em pares circundados por pequenos filamentos finos (Yuen et al., 2015).

Em resumo, mutações no gene $L M O D 3$ estão relacionadas a forma de MN neonatal grave e se apresenta com achados característicos a microscopia eletrônica.

\subsubsection{Miosina XVIIIB (MYO18B)}

Mutação no gene $M Y O 18 B$ foi descrita recentemente em dois casos pertencentes a duas famílias, não relacionadas, com síndrome de Klippel-Fei, MN e dismorfismos faciais (MIM616549). A mutação encontrada foi nonsense em homozigose S2302X (Alazami et al., 2015), uma outra variante, ainda de significado indeterminado, foi relacionada a um quadro grave e letal de $\mathrm{MN}$ com cardiopatia. A análise por Western-Blotting mostrou a proteína truncada. Ao nascimento o paciente apresentou hipotonia grave, retrações tendíneas, 
disfagia, e ainda achados dismórficos faciais como: palato arqueado, implantação baixa de orelhas, clinodactilia e pectus excavatum (Malfatti et al, 2015). A miosina $X V I I I B$ é expressa em músculo cardíaco e esquelético, mas pode ser que a cardiopatia seja relacionada a sítios específicos ou a truncagem da proteína, já que foi vista no caso de Malfati (2015) e não nos pacientes com Síndrome de Klippel-Feil descritos por Alazami (2015). Por isso, o gene MYO18B, apesar de ainda não listado nas causas de $\mathrm{MN}$, deve ser um candidato importante para pacientes com MN e cardiopatia grave precoce e/ou achados dismórficos faciais.

\subsubsection{Miopatia com núcleos centrais}

As miopatias centronucleares ( $\mathrm{MCN})$ são $\mathrm{MC}$ caracterizadas pela internalização nuclear sem achados proeminentes de degeneração e regeneração somadas a falhas específicas nas colorações de atividade oxidativa. Quanto ao padrão de herança, pode ser classificada em herança ligada ao X, herança dominante e herança recessiva(Jungbluth et al., 2014).

A miopatia centronuclear de herança ligada ao X ou miopatia miotubular é causada por mutação no gene MTM1 que codifica a proteína miotubularina e acomete neonatos do sexo masculino. Apresentam-se com hipotonia neonatal grave, dificuldade de sugar, engolir e insuficiência respiratória. Um achado clínico importante é a oftalmoplegia, mas pode não ser observado logo ao nascer. A mortalidade é alta e precoce e os que sobrevivem são normalmente dependentes de ventilação mecânica (Jungbluth et al., 2008). A histopatologia é característica. As fibras musculares se apresentam com núcleo grande, central 
e único. Nas colorações de atividade oxidativa as fibras podem mostrar um halo pálido na periferia (Bevilacqua et al., 2009).

As formas autossômicas dominantes são relacionadas ao gene da dinamina (DNM2). Sua apresentação clínica pode variar entre formas graves de início na infância a formas leves compatíveis com vida adulta. Os principais achados clínicos são hipotonia, fraqueza muscular de predomínio proximal, fraqueza facial, ptose palpebral, oftalmoplegia e, em casos mais graves, contraturas, limitação da abertura da boca e pé cavo (Bohm et al., 2012). A histologia relacionada a mutações no gene DNM2 mostra uma tríade específica de achados: (1) organização radial das organelas sarcoplasmáticas conferindo o aspecto em "roda de carroça"; (2) aumento da internalização nuclear e (3) predomínio e atrofia de fibras tipo 1(Bohm et al., 2012).

As formas autossômicas recessivas são relacionadas com o gene BIN1. Apesar de raras estão associadas a uma grande variabilidade fenotípica. $\mathrm{Na}$ histologia pode-se observar fibras do tipo 1 atrofiadas e arredondadas com núcleo grande e central na maioria das fibras (Claeys et al., 2010; Sher et al., 1967).

A maioria dos genes associados a miopatia com núcleos centrais estão envolvidos nos mecanismos de remodelamento e reparo de membrana. Estes processos envolvem proteínas que atuam na regulação de lipídios que por sua vez participam da organização do citoesqueleto (Jungbluth et al., 2008). 


\subsubsection{Miopatia com presença de cores}

Cores são definidos histopatologicamente por áreas destituídas de atividade oxidativa, encontradas nas colorações específicas para atividade oxidativa (NADH, SDH) na biópsia muscular.

A miopatia com core pode ser classificada dependendo da morfologia do core em miopatia central core, quando core é único e central, e em miopatia multi/minecores quando são vários e/ou pequenos (North, 2011).

O gene do receptor do canal da rianodina (RYR1) é o mais frequentemente implicado na miopatia central core, principalmente nas formas de herança dominante. Mutações no gene da selenoproteína (SEPN1) podem estar envolvidas nos casos de herança recessiva (Wu et al., 2006).

Doença multi/minecores é mais heterogênea do ponto de vista clinico e genético. Casos dominantes estão relacionados ao gene $R Y R 1$ e casos recessivos ao gene SEPN1 (Ferreiro et al., 2002). Clinicamente os casos podem separados entre uma forma clássica, uma forma com oftalmoplegia externa, uma forma com envolvimento das mãos e uma forma neonatal grave, todas associadas ao gene RYR1. Os casos relacionados com gene SEPN1 apresentam-se tipicamente com espinha rígida, escoliose, e comprometimento respiratório desproporcional ao grau de fraqueza apendicular (Jungbluth et al., 2011).

Os casos dominantes se iniciam na infância com hipotonia e atraso na aquisição dos marcos motores. Podem estar presentes mialgia, câimbras, piora com exercícios e rabdomiólise. A distribuição da fraqueza é tipicamente proximal com predomínio em cintura pélvica e musculatura axial. Em adultos pode ser exclusivamente axial (Jungbluth et al., 2011). Envolvimento bulbar e 
respiratório são raros, mas já foram relatados em neonatos mais graves (Romero et al., 2003).

O gene RYR1 é muito grande, sendo difícil o seu estudo por técnicas convencionais. Pode estar relacionado a outras formas de miopatia como MCN (Wilmshurst et al., 2010), DCTF (N. F. Clarke et al., 2010), MCl e hipertermia maligna (Denborough et al., 1973).

O gene SEPN1 também está associado a outras miopatias como: distrofia muscular congênita com espinha rígida e DCTF (Moghadaszadeh et al., 2001).

Recentemente foi descrita miopatia com cores excêntricos causada pelo gene MYH7 (Romero et al., 2014).

\subsubsection{Miopatias com variação no tamanho das fibras e achados inespecíficos}

Em 1970, Brooke usou pela primeira vez o termo desproporção congênita de tipo de fibras (DCTF) para descrever crianças com histologia muscular demonstrando uma importante variação entre o tamanho das fibras tipo 1 e tipo 2 na ausência de outras alterações estruturais, na maioria das vezes com hipotrofia e predomínio de fibras tipo 1 e hipertrofia de fibras tipo 2. Nesta descrição os pacientes apresentavam luxação de quadril, deformidades nos pés, contraturas, cifoescoliose, palato arqueado, hipotonia e fraqueza muscular (Clancy et al., 1980).

Atualmente o diagnóstico DCTF é um dos mais controversos na miologia. A nomenclatura é utilizada para pacientes com achados clínicos de MC e histologia muscular com fibras tipo 1 consistentemente menores que as tipo 2 , 
originalmente descrito com $12 \%$ de desproporção entre as fibras, na ausência de outros achados estruturais (Brooke et al., 1969).

Com o passar do tempo foi constatado que várias outras doenças neuromusculares podem cursar com desproporção entre as fibras o que sugere que este seja um achado comum nestas doenças e não um diagnóstico isolado. Alguns exemplos de doenças que cursam com desproporção de tipo de fibras são: distrofia miotônica, doenças cerebelares, doenças centrais, doenças de nervo periférico e doenças de coluna anterior da medula. Com relação aos achados clínicos, o maior problema do diagnóstico de DCTF é que existem poucas séries clínicas até o momento e o relato de Brooke permanece o maior relato descritivo deste grupo (N. F. Clarke et al., 2003).

Mesmo com essas dificuldades, DCTF ainda permanece como um diagnóstico de exclusão para aquele grupo de indivíduos que apresentam quadro clínico compatível com miopatia congênita e os achados histológicos característicos na biópsia muscular.

Os achados clínicos mais comuns são: fraqueza muscular de predomínio proximal, face alongada, palato arqueado, diminuição ou ausência de reflexos tendinosos. Envolvimento cardíaco observado em raros casos. Pacientes mais graves podem apresentar retrações, oftalmoplegia, envolvimento respiratório (N. F. Clarke et al., 2003).

O padrão de herança é heterogêneo e já foram descritas heranças ligadas ao X, autossômicas dominantes ou autossômicas recessivas (N. F. Clarke et al., 2003). Os três genes mais frequentemente associados são: TPM3 (N. F. Clarke et al., 2008); ACTA1 (Laing et al., 2004) e SEPN1 (N. F. Clarke et al., 2006). O 
gene TPM3 é o mais frequente e até o momento mais de 6 mutações foram associadas a este diagnóstico (N. F. Clarke et al., 2008). Apesar dos NGS, a base genética na maioria dos pacientes ainda permanece desconhecida.

Além da DCTF, existem também pacientes com achados clínicos de miopatia congênita que se apresentam com achados inespecíficos na biópsia muscular como por exemplo predomínio de fibras tipo 1, predomínio de fibras tipo 2, falhas focais na arquitetura interna e a própria variação no tamanho das fibras. Em decorrência da dificuldade em ver DCTF como um diagnóstico isolado, optamos por estudar todos estes pacientes com achados inespecíficos na biópsia muscular em um grupo ao qual denominamos $\mathrm{MCl}$.

\subsubsection{Diagnóstico diferencial das miopatias congênitas}

O diagnóstico diferencial das miopatias congênitas é feito entre as síndromes que causam hipotonia neonatal ("Síndrome do Bebê Hipotônico"), sendo as princiapais a síndrome de Prader-Willi, atrofia espinhal progressiva, miopatias metabólicas incluindo doença de Pompe, distrofias musculares congênitas e síndromes miastênicas congênitas. Alguns padrões de acometimento podem auxiliar neste diagnótico como, a presença de envolvimento facial importante, a presença ou ausência de ptose palpebral, hipotonia neonatal generalizada, hiporreflexia, envolvimento respiratório e bulbar. Sensibilidade e inteligência são habitualmente normais neste grupo de doenças, o que auxilia no diferencial com doenças centrais. Os principais achados clínicos não usuais nos pacientes com MC são: reflexos aumentados, anormalidades em sistema nervoso central (SNC), fasciculações de língua, 
dismorfismos faciais e anormalidade metabólicas como aumento de lactato ou acidose metabólica (North, 2011).

Após afastadas doenças do neurônio motor, doenças da junção neuromuscular e doenças centrais, investigação gira em torno basicamente da biópsia muscular que irá demostrar os elementos estruturais necessários para a sua definição diagnóstica. Os valores da CPK são habitualmente normais ou discretamente elevados, quando o aumento é maior que cinco vezes o valor de referência o quadro de distrofia muscular deve ser considerado. A eletroneuromiografia auxilia no diferencial com neuropatias periféricas e doenças do neurônio motor, mas pode também evidenciar potenciais miopáticos sugerindo o diagnóstico de miopatia.

Exames imagem de músculo (ultrassonografia, tomografia computadorizada e ressonância) podem ser utilizados no diagnóstico e seguimento dos pacientes. Estes métodos oferecem pistas importantes para o estudo genético. A detecção de padrões de acometimento apresentados pelo paciente pode guiar o estudo molecular, evidenciar outras áreas acometidas não detectadas pelo exame físico e ainda determinar o melhor sítio para a realização da biópsia (Castiglioni et al., 2014).

Cada método oferece vantagens e desvantagens em relação a técnica utilizada. Na escolha do método, os principais aspectos a serem analisados são: necessidade de sedação, duração do exame e a sua abrangência a nível de plano muscular (Oishi et al., 1998). O Ultrassom (USG) tem sido utilizado na investigação e no acompanhamento das doenças musculares desde 1980, é um método rápido, não invasivo e avalia bem o plano muscular superficial, no 
entanto, depende de um operador experiente para que seja realizado e analisado de maneira apropriada. A tomografia computadorizada (TC) oferece boas imagens de planos musculares superficiais e profundos. Apesar da sua qualidade de imagem, é pouco utilizada na prática clínica devido a grande quantidade de radiação necessária na obtenção das imagens. A ressonância magnética de músculo (RM) oferece boas imagens de planos superficiais e profundos, discrimina achados inflamatórios, fibrose, substituição por tecido conjuntivo e atrofia muscular. As principais desvantagens são a sua longa duração, alto custo, a necessidade de sedação para crianças e o fato de algumas deformidades não permitirem o adequado posicionamento dentro da máquina, impossibilitando exame (North et al., 2014; Oishi et al., 1998).

\subsubsection{Abordagens no tratamento das miopatias congênitas}

Até o momento não há nenhum tratamento efetivo para miopatia nemalínica. No entanto, tratamentos sintomáticos como suporte ventilatório, fisioterapia, fonoterapia, alimentação via sonda e órteses têm sido práticas modificadoras no perfil destes doentes e na sua sobrevida (Wallgreen-Pettersson C et al, 2004).

A MN representa um dos mais comuns subtipos de MC. Sete dos dez genes implicados com esta doença codificam o filamento fino, que é um componente essencial ao funcionamento normal do músculo. Apesar de todos os avanços na compreensão dos mecanismos patofisiológicos dessa miopatia, assim como os outros tipos de MC, não há atualmente cura e o manuseio dos pacientes é puramente sintomático ((Jungbluth et al., 2016)Nowak et al, 2013). Inúmeros compostos farmacológicos e suplementos já foram testados. Como exemplo a L- 
tirosina, que demostrou melhora da fadiga em pacientes com $\mathrm{MN}$ em um estudo piloto com 5 pacientes (Ryan et al., 2003). Recentemente, um relato demonstrou efeitos benéficos do uso de piridostigmina em um paciente com mutação no gene $K L H L 40$, sugerindo uma provável associação com defeitos na transmissão neuromuscular nestes pacientes (Natera-de Benito et al., 2016). Drogas visando o filamento fino e suas interações estão sendo desenvolvidas como por exemplo CK-20017357, Omecamtiv Mecarbil (CK-1827452), mas não são muito promissoras na $\mathrm{MN}$ (Jungbluth et al., 2016). Em alguns pacientes com mutações no gene ACTA1, o upregulation do gene $A C T C$, que codifica a proteína alpha-actina cardíaca, também tem sido estudado (Ravenscroft, McNamara, et al., 2013).

As miopatias com core são relacionadas com mutações no gene RYR1 ou SEPN1 e agora mais recentemente TTN (Chauveau et al., 2014) e MYH7 (Cullup et al., 2012). Por causa da alta frequência com que vem sendo encontradas mutações no gene RYR1 em pacientes com vários subtipos de miopatia, alternativas terapêuticas para estas mutações tem sido um importante alvo da pesquisa (Jungbluth et al., 2016). 


\section{JUSTIFICATIVA}

As miopatias congênitas formam um grupo amplo, embora raro, de miopatias dentro do grupo das doenças neuromusculares. Seus subtipos se diferenciam basicamente pelos aspectos histológicos. Com o desenvolvimento de novas técnicas de sequenciamento, estabelecer o diagnóstico molecular e correlacionar com o fenótipo correspondente, tem ganhado cada vez mais importância. Ainda pouco se sabe sobre os mecanismos fisiopatológicos que envolvem as miopatias congênitas. O diagnóstico molecular permite uma nova visão sobre estas doenças, auxilia na compreensão destes mecanismos, oferece aos pacientes um conhecimento mais detalhado sobre a sua doença e ainda e orienta a idealização de novas terapêuticas.

Este estudo procurou analisar de forma mais abrangente os aspectos clínicos, histológicos e moleculares de pacientes com miopatia nemalínica e miopatias com alterações mínimas na nossa população, incluindo pacientes de dois grandes centros de investigação em doenças neuromusculares na cidade de São Paulo. Existem poucos estudos semelhantes na população brasileira e por isso não sabemos se o perfil molecular dos nossos pacientes corresponde ao observado em outros países. 


\section{OBJETIVOS}

- Descrever o quadro clínico e histológico de pacientes com miopatia congênita nemaliníca e com miopatia congênita com achados leves e inespecíficos (alterações mínimas).

- Identificar mutações nos genes ACTA1, TPM3, MYH7 e SEPN1 em pacientes com miopatia congênita nemaliníca e com miopatia congênita com achados leves e inespecíficos, e correlacionar o quadro clínico e histológico com as mutações encontradas.

- Analisar a utilidade do sequenciamento de nova geração nestes dois grupos de pacientes. 


\section{PACIENTES E MÉTODOS}

\subsection{Pacientes}

Foram selecionados através de laudos de biópsia muscular pacientes com diagnóstico histológico de $\mathrm{MN}$ e $\mathrm{MCl}$ em dois grandes bancos de biópsia muscular da cidade de São Paulo: 1) Laboratório de biópsia muscular do Hospital das Clínicas, do Departamento de Neurologia, da Faculdade de Medicina da Universidade de São Paulo (HC-FMUSP), e 2) Laboratório de biópsia muscular do Setor de doenças neuromusculares, da Disciplina de Neurologia Clínica, da Universidade Federal de São Paulo (UNIFESP). No grupo de MN foram incluídos pacientes com este diagnóstico histológico e no grupo de $\mathrm{MCl}$ foram incluídos pacientes com quadro clinico de início nos primeiros anos de vida, com evolução relativamente estável, valores de CPK próximos da normalidade e com achados leves e inespecíficos na biópsia muscular.

Os pacientes foram convocados para atendimento no seu respectivo centro de origem, ou no prédio dos ambulatórios do HC-FMUSP ou no ambulatório de Doenças Neuromusculares da UNIFESP. Todos foram convocados a comparecer de livre espontânea vontade ao local determinado, já orientados de que seria um atendimento voltado para pesquisa e que o seu não comparecimento não influenciaria no seu seguimento clínico. Todos os pacientes assinaram o termo de consentimento livre e esclarecido. O projeto foi aprovado pelo comitê de Ética do HC-FMUSP sob o protocolo de pesquisa CAPPesq (número parecer: 294320) aprovado em 05 de junho de 2013.

Após a assinatura do termo de consentimento, os pacientes foram submetidos à anamnese, exame físico e análise de exames complementares já 
realizados. Neste mesmo atendimento, o paciente ou o responsável, receberam pedidos para coleta de sangue periférico para a extração de DNA. Pacientes que tiveram seu diagnóstico concluído durante a execução do trabalho também foram incluídos sob os mesmos critérios. Para alguns pacientes foram solicitados alguns exames que fazem parte da rotina do atendimento tais como: ecocardiograma transtorácico, espirometria, holter cardíaco, eletrocardiograma e radiografia de tórax.

\subsubsection{Critérios de inclusão}

1. Pacientes de qualquer idade e sexo com diagnóstico histológico de miopatia nemalínica,

2. Pacientes com quadro clínico de miopatia congênita com diagnóstico histológico muscular inespecífico, tais como, desproporção congênita de fibras, predominância de fibras do tipo 1, predomínio de fibras tipo 2 e falhas focais na arquitetura das fibras demonstradas pelas reações histoquímicas que avaliem a atividade oxidativa.

\subsubsection{Critérios de exclusão}

1. Pacientes com aspecto distrófico franco na biópsia muscular, sem alterações estruturais específicas.

2. Presença de achados histológicos relacionados com outras formas de miopatias congênitas estruturais, tais como, miopatia centronuclear e miopatia do central core. 


\subsection{Análise Histológica}

Os pacientes foram selecionados conforme seu diagnóstico histológico, ou seja, todos os pacientes já haviam realizado previamente a biópsia muscular e as lâminas com as reações histológicas estavam armazenadas no serviço de origem.

Rotineiramente, após a coleta do fragmento de músculo, este é congelado utilizando isopentano resfriado no nitrogênio líquido ou diretamente no nitrogênio líquido protegido por talco. Os fragmentos são montados em uma placa de cortiça utilizando tissuetek, são submetidos a cortes finos onde são aplicadas as colorações de rotina e histoquímicas: hematoxilina/eosina (HE), tricrômico de Gömöri modificado (GO), ácido periódodico Schiff (PAS),"oil red"(ORO), nicotinamida adenine dinucleotídeo desidrogenase - tetrazolium redutase (NADH-TR), citocromo C oxidase (COX), succinato desidrogenase (SDH) e adenosina trifosfatase (ATPase) em diferentes pHs (9.3, 4.6 e 4.3).

Todas as biópsias foram revisadas sob a supervisão do Prof. Dr. Edmar Zanoteli e os seguintes aspectos foram analisados:

- Presença de variabilidade de tamanho entre as fibras musculares;

- Presença de aumento do tecido conjuntivo endomisial/perimisial aspecto avaliados em ausente ou grau leve (+), moderado (++) ou intenso (+++);

- Presença de centralizações nucleares;

- Relação quantitativa entre fibras tipo 1 e 2 - aspectos que foram avaliados sob a forma percentual; 
- Presença de agregados (bastões, massas citoplasmáticas) bem como sua localização no interior da fibra (subsarcolemal, intracitoplasmático, intranuclear) e percentagem de fibras afetadas.

- Nas reações oxidativas (SDH e NADH), foram avaliadas a presença de falhas oxidativas focais intracitoplasmáticas inespecíficas, falha central única (central-core), falhas intracitoplasmáticas múltiplas (minicores) e aspecto em mordida de traça.

\subsection{Avaliação clínica}

A avaliação clínica de todos os pacientes foi padronizada em uma ficha de atendimento própria do ambulatório de doenças musculares do HC-FMUSP (anexo). Esta ficha inclui história clínica detalhada (gestacional, neonatal, de desenvolvimento neuropsicomotor), evolução clínica, história familiar, exame físico geral e neurológico. No exame neurológico foram avaliados o desenvolvimento neuropsicomotor, força muscular com graduação de músculos selecionados pela escala MRC (medical research consil), provas de sensibilidade superficial e profunda, equilíbrio e marcha, coordenação e presença de movimentos involuntários. Foram avaliadas também a presença de deformidades osteoesqueléticas, tais como cifoescoliose, hiperlordose, retrações tendíneas, deformidades torácicas e espinha rígida.

Resultados de exames subsidiários que são eventualmente solicitados durante o acompanhamento ambulatorial foram anexados a avaliação, incluindo dosagem sérica de CPK, exames de imagem muscular e do sistema nervoso central, eletroneuromiografia, provas de função pulmonar, polissonografia, 
ecocardiograma transtorácico, radiografia de tórax e eletrocardiograma.

\subsection{Estudo genético}

O estudo genético foi realizado de maneira sequencial (Diagramas 1, 2 e 3) e individualizado após a discussão clínica visando estabelecer o fenótipo do paciente. Iniciamos com o sequenciamento Sanger do gene ACTA1 seguido do gene TPM3 no laboratório de investigação médica (LIM15/45 FM/USP) e, SEPN1 e MYH7 no laboratório da divisão de neurogenética e doenças neuromusculares da infância do National Institute of Neurological Disorders and Stroke / National Institutes of Health (NINDS/NIH) - Bethesda/MD. O sequenciamento exômico (SE) e painéis gênicos também foram realizados com a colaboração do NINDS/NIH para alguns casos selecionados.

\subsubsection{Extração de DNA e sequenciamento Sanger}

Após a assinatura do termo de consentimento livre e esclarecido, foi coletada uma amostra de 5 a $10 \mathrm{ml}$ de sangue periférico dos pacientes e dos familiares no Laboratório Central do Hospital das Clínicas da FMUSP. Este material foi enviado para o LIM45 (Disciplina de Neurologia Experimental- FMUSP), onde foi realizada a extração de DNA linfocitário usando protocolo descrito por Miller et al. Para os pacientes da UNIFESP, o material coletado foi transportado no mesmo dia da coleta para o LIM45 (FMUSP) onde foi realizada a extração de DNA. 
A extração de DNA a partir de leucócitos de sangue periférico, as reações em cadeia de polimerase (PCR) - etapa inicial do sequenciamento Sanger, e a purificação do produto de PCR foram realizados no LIM45. O sequenciamento foi realizado no LIM25 e o resultado foi analisado no LIM45 utilizando o programa Mutation Surveyor e NCBI Blast. Após esta primeira parte, o DNA dos pacientes ainda sem diagnóstico foi enviado para a divisão de neurogenética e doenças neuromusculares da infância do NINDS/NIH, onde a autora, sob supervisão do Dr Carsten Bonnemann, complementou o estudo molecular.

\subsubsection{Sequenciamento dos genes ACTA1, MYH7, TPM3 e SEPN1}

O gene ACTA1 possui 7 exons sendo 6 codificantes. Os fragmentos de DNA incluindo a região codificante foram amplificados em termocicladora da marca Eppendorf utilizando-se pares de oligonucleotídeos de acordo com método descrito por Novak et al, 1999. Neste método foi obtida uma solução com volume final de $25 \mu \mathrm{L}$ com cerca de 100 ng de DNA, 10 mM de Tris- $\mathrm{HCl}$ com pH de 8.3 como tampão de reação, $200 \mu \mathrm{M}$ de dNTP, 1.5 a 2.0 mM MgCl2, 10 pmol de cada primer e $1 \mathrm{U}$ de Taq polymerase. O Protocolo de PCR do termo ciclador foi específico para cada exon. O produto de PCR foi corrido em gel de agarose a $2 \%$ por 50 min para verificar a qualidade da amplificação. Em seguida o produto foi purificado e enviado para o sequenciamento.

O gene TPM3 possui 10 exons e existem mutações descritas ao longo de todo o gene. Este gene foi estudado em todos os pacientes com aspecto histológico inespecífico. A PCR foi preparada com mix idêntico ao do gene ACTA1. O Protocolo de PCR do termociclador foi o mesmo para todos os exons. 
O produto de PCR foi corrido em gel de agarose a $2 \%$ por 50 min para verificar a qualidade da amplificação. Em seguida o produto foi purificado e enviado para o sequenciamento.

O gene SEPN1 possui 13 exons. Todos os exons foram amplificados e sequenciados no NINDS/NIH para os pacientes selecionados. O volume total da PCR foi de $30 \mu \mathrm{L}$ contendo $19,45 \mu \mathrm{L}$ de água para PCR, $3 \mu \mathrm{L}$ de tampão para PCR sem magnésio, 2,4 $\mu \mathrm{L}$ de $\mathrm{MgCl} 2$ a 10\%, 2,5 $\mu \mathrm{L}$ de DnTP, $1 \mu \mathrm{L}$ de cada primer a $10 \%$ e $1,5 \mu \mathrm{L}$ da enzima Taq. Foi utilizado o protocolo de PCR do termociclador do próprio serviço com temperatura de anelamento de 58 graus. Após verificado o produto de PCR em gel de agarose a $1,5 \%$ por $15 \mathrm{~min}$, a amostra foi enviada para o sequenciamento.

A amplificação do exon 1 necessitou de programa próprio devido à alta percentagem de GC. Foi utilizado o "Kit Roche GC-Riche PCR System n12140306001". Para a elaboração do mix de PCR foi utilizado $13 \mu \mathrm{L}$ de água para PCR, $5 \mu \mathrm{L}$ de DNTP a $1 \mu \mathrm{M}, 1 \mu \mathrm{L}$ de cada primer (forward e reverse), $2 \mu \mathrm{L}$ do DNA e 10 $\mu \mathrm{L}$ de solução 3 do kit (GC-Resolutionsolution \#3). Após misturar e centrifugar foi acrescentado mais $4 \mu \mathrm{L}$ de água para PCR, $10 \mu \mathrm{L}$ da solução 2 do Kit (5xGC-Rich buffer \#2) e 1 $\mu \mathrm{L}$ da solução 1 do Kit (enzime Mix \#1). O total desta PCR foi de $47 \mu \mathrm{L}$. Ela foi processada no termociclador a $95^{\circ} \mathrm{C}$ por $3 \mathrm{~min}$, $95^{\circ} \mathrm{C}$ por $30 \mathrm{~s}, 55^{\circ} \mathrm{C}$ por $30 \mathrm{~s}, 68^{\circ} \mathrm{C}$ por $1 \mathrm{~min}$ e $15 \mathrm{~s}$, em um total de 29 ciclos, seguido de incubação a $68^{\circ} \mathrm{C}$ por 7 min e será mantida a $18^{\circ} \mathrm{C}$. O produto de $\mathrm{PCR}$ foi verificado em gel de agarose a $1,5 \%$ por $15 \mathrm{~min}$, enviado para sequenciamento e analisado. 
O gene MYH7 possui 38 exons, sendo estudado apenas o exon 34 nos pacientes selecionados. O volume total da PCR foi de $30 \mu \mathrm{L}$ contendo $19,45 \mu \mathrm{L}$ de água para PCR, $3 \mu \mathrm{L}$ de tampão para PCR sem magnésio, $2,4 \mu \mathrm{L}$ de $\mathrm{MgCl} 2$ a $10 \%, 2,5 \mu \mathrm{L}$ de DnTP, $1 \mu \mathrm{L}$ de cada primer a $10 \%$ e $1,5 \mu \mathrm{L}$ da enzima Taq. Foi utilizado o protocolo de PCR do termociclador do próprio serviço com temperatura de anelamento de 58 graus. Após verificado o produto de PCR em gel de agarose a $1,5 \%$ por $15 \mathrm{~min}$, a amostra foi enviada para o sequenciamento. A sequência de oligonucleotídeos utilizados constam na tabela 2. 
Tabela 2 - Sequência de oligonucleotídeos para amplificação de regiões codificadoras dos genes ACTA1, TPM3, SEPN1 e MYH7.

\begin{tabular}{|c|c|c|}
\hline Exon & Sequência $F$ & Sequência $\mathbf{R}$ \\
\hline ACTA1 - exon 1 & TGG CTC AGC TTT TTG GAT TCAG & GGC TGA CCA GGT GAA CCG ACT G \\
\hline ACTA1 - exon 2 & TGA GAC TTC TGC GCT GAT GCA & GTG GCA CCA GGC TGG CTT ACG \\
\hline ACTA1 - exon 3 & CAC CCG GAG CGG CGT TAA CG & GCG CGC GGG AGA GAG TGA GT \\
\hline ACTA1 - exon 4 & CGC TGA GCG CCT AGC CTC GG & TGC GGA GGG CAG AAG CAG GA \\
\hline ACTA1 - exon 5 & CGG CGG CCT GAG TGA GGG CT & GGG GAG CGT GAG CAG AAG CT \\
\hline ACTA1 - exon 6 & CCC GGC CCG AGC TTC TGC TC & CCG ACA GCC CGC GCA GGC CAC C \\
\hline ACTA1 - exon 7 & CTC CAG GGT GAG GTC TCC CC & TAT GTA CAC GTT ATA AAC ACT G \\
\hline TPM3 - exon 1 & CCT ACC AAC AGC CAC TGC TCA & CTG TTT АCT TCT TTC TTC TG \\
\hline TPM3 - exon 2 & TCG CCT CTG CTT CCC TTG TC & TAT AAG GAA ATC TTG ATC AGA AC \\
\hline TPM3 - exon 3/4 & TTT TGT TCC TAT TTC TGG CAG & GTT TGG GGA GCT AGA TAC TC \\
\hline TPM3 - exon 5 & TTC CCT TTT CCT CTC CTG TG & ATG CGT GTC TCC AGT CTT TC \\
\hline TPM3 - exon 6/7 & TCT ACT CTG AAA TTT TTA ATC TAC & CTA TTT CAA TCC CTA CTC CAG \\
\hline TPM3 - exon 8 & TCC TCC CTG TGG TTC CTG TG & CAG CCC CAC TCT ACT GTC AG \\
\hline SEPN1-exon 1 & CCC CGC CCC GCT CTT TCG CTT C & GCG CTC CCG CCC CCA GCC AGC TC \\
\hline SEPN1-exon 2 & ACA TTT GCA CAG ATG GAC CG & CCT CGC AGA CCA AAG AAT GT \\
\hline SEPN1-exon 3 & CCC CAG TTT CCC AAG CTA GA & ACA CCT GTA ATT CCA GCA CTT \\
\hline SEPN1-exon 4 & GGC TAT CCT GAA ACT AAA ATG CG & ATG CTT CTC TCT CCT GCT CC \\
\hline SEPN1-exon 5/6 & CTG CGC GGA TAT TGC TAA GC & CTT TCT GAA CCC TCA CGT GC \\
\hline SEPN1-exon 7 & GAG CGA CAT TTG GAG AGC C & TCA TTC TCT TGC CTG CCT CA \\
\hline SEPN1-exon 8/9 & CCA GAA TCC CAG TGG CTC T & TCC TGG CCA CAA GTG ATT CT \\
\hline SEPN1-exon 10 & AGT AGC ACC CAC TTC ACA CA & GTT TGA ACC CAG TCT GCC AG \\
\hline SEPN1-exon 11/12 & AAG CCT AAT CTC AGC CCA GG & GGA CAA CGG AGG CTT AGA CT \\
\hline SEPN1-exon 13 & AGG GTG ATG AGA TGG TGT CG & CCG AGT GAC AGT CAG AGC TA \\
\hline MYH7-exon 34 & TCT TCA TAG CTG GCT CTC CC & GAT CAG GAG AGT GGG CAT GA \\
\hline
\end{tabular}




\subsubsection{Sequenciamento de nova geração (NGS)}

As plataformas de NGS permitem o sequenciamento paralelo de milhões de fragmentos de DNA simultaneamente. Com a atual redução de custo destas técnicas, o seu uso tem se tornado mais acessível e de grande importância nas doenças genéticas. O resultado do sequenciamento retorna ao laboratório nos formatos SAM ou BAM juntamente com o arquivo de variantes. Estes arquivos serão convertidos em formatos apropriados para a análise bioinformática. Nossos arquivos foram analisados no formato vcf utilizando um software gratuito - Varsifter.

As técnicas de NGS têm se mostrado muito úteis no estudo molecular de doenças não diagnosticadas, no entanto a interpretação dos resultados deve ser cautelosa. O SE produz uma lista de genótipos na ordem de $10^{4}$ por paciente, quando realizado apenas no caso-único, podendo ser menor quando realizado em mais de um membro afetado ou em trio (paciente, mãe e pai). Esta lista de genótipos inclui polimorfismos comuns, variantes raras e falso-positivos. A análise inicial é feita seguindo uma filtragem a fim de se detectar variantes potencialmente causadoras da doença. O primeiro passo é verificar a qualidade do sequenciamento e a sua cobertura para regiões de interesse, estabelecemos nos nossos resultados que a cobertura deveria ser de no mínimo 10.

A filtragem é baseada em fatores como frequência populacional, segregação, expressão no tecido em questão e consequências da variante na função do gene, preditas por modelos pré-estabelecidos. A filtragem pela frequência populacional é uma tentativa de remover polimorfismos comuns que provavelmente não causam doença. Presume-se que a variante causadora de 
doença seja rara, de alta penetrância e responsável por um amplo efeito fenotípico. Um banco de dados público frequentemente usado nesta etapa é o dbSNP (Sherry et al., 2001), no qual encontra-se variantes genéticas comuns já estudadas. Para estarem no banco não é exigido uma frequência mínima de alelo nem que sejam obrigatoriamente neutras, portanto essas variantes devem ser analisadas com cautela e não devem ser excluídas da análise indiscriminadamente porque este banco pode conter variantes patogênicas, cerca de $8 \%$ das sequencias encontradas também estão descritas no Human Gene Mutation Database (HGMD) (Won et al., 2008). O projeto 1000 genomas também é uma fonte importante na detecção de polimorfismos, sendo uma importante ferramenta na filtragem destas variantes (L. Clarke et al., 2016).

Após a filtragem, devemos ficar com uma lista de variantes pequena o suficiente para possibilitar a sua interpretação. Nesta etapa analisa-se individualmente cada uma das variantes quanto a predições de patogenicidade, expressão no tecido de interesse, padrão de herança estabelecida, dentre ouros aspectos. Existem muitos softwares disponíveis que são ferramentas importantes na associação entre variantes e síndromes clínicas, neste estudo utilizamos: Online Mendelian Inheritance in Man (OMIM), Pubmed, HGMD, NCBI's ClinVar.

Neste estudo foram incluídas apenas variantes que alteram a estrutura da proteína como variantes em truncagem (stop loss, start loss ou frameshift), variantes missenses, em sítios de splicing e variantes intrônicas na transição intron/exon (foi considerado até 8 bases margeando o exon). 
Algumas doenças já possuem uma lista própria de genes previamente associados a doença, como no caso da miopatia nemalínica. Nestes casos, o estudo se concentrou inicialmente nestes genes.

Após a análise do sequenciamento é necessário confirmar as variantes candidatas. Esta validação é normalmente feita utilizando-se um método já aprovado pelo FDA. Como por exemplo, o sequenciamento convencional (Sanger).

Para considerar "diagnóstico genético" foi exigido que o fenótipo da doença no OMIM fosse compatível com os achados do paciente em análise, que o genótipo encontrado fosse compatível com o padrão de herança encontrada no OMIM e ainda que a variante em si já tenha sido descrita em um fenótipo semelhante ou que pertença a uma mesma classe funcional de alguma variante relatada em um quadro semelhante (Zhu et al., 2015).

Os arquivos vcf e BAM do exoma dos pacientes e os filtros para doenças neuromusculares e miopatia nemalínica foram fornecidos pelo grupo do NINDS/NIH e analisados individualmente no programa Varsifter pela própria autora do trabalho, com supervisão do Dr. Osório Abath Neto (NINDS/NIH), colaborador do trabalho. 


\subsubsection{Algoritimo para o estudo genético}

O estudo genético foi realizado de maneira sequencial de acordo com a hipótese diagnóstica. Portanto dividimos o estudo em duas partes:

(1) Pacientes com MN (diagrama 1): foram incluídos 23 pacientes com MN pertencentes a 20 famílias. Foram avaliadas as características clínicas e histológicas de todos os pacientes. O estudo genético foi feito inicialmente em um paciente afetado de cada família. Uma provável herança recessiva foi estabelecida em quatro famílias (família 1, 3, 15 e 16). Devido à baixa probabilidade do envolvimento dos genes ACTA1 e TPM3, o DNA de um paciente afetado de cada uma destas famílias foi enviado para o SE, bem como um paciente (12.1) com achados atípicos na biópsia muscular. Nas restantes 15 famílias, foram sequenciados os 6 exons codificantes do gene ACTA1. Após a análise clínica optamos por não realizar o estudo do gene TPM3 em todos os pacientes com MN por causa da baixa frequência de casos que são atribuídos a este gene. Sendo assim, nove dos dez exons condificantes deste gene foram estudados em 5 destas famílias (famílias 5, 6, 7, 8 e 9). O exon 1 do gene TPM3 não foi sequenciado devido a dificuldades técnicas em sequenciar exons ricos em GC. Portanto, não foi possível excluir completamente a presença de mutações neste gene. Em apenas 3 pacientes o diagnóstico molecular foi concluído com a presença de variantes patogênicas no gene ACTA1. O DNA de um membro afetado de cada uma destas 12 famílias restantes foi encaminhado para o SE. 
Diagrama 1 - Esquema do estudo genético dos pacientes com MN mostrando o local onde cada etapa foi realizada.

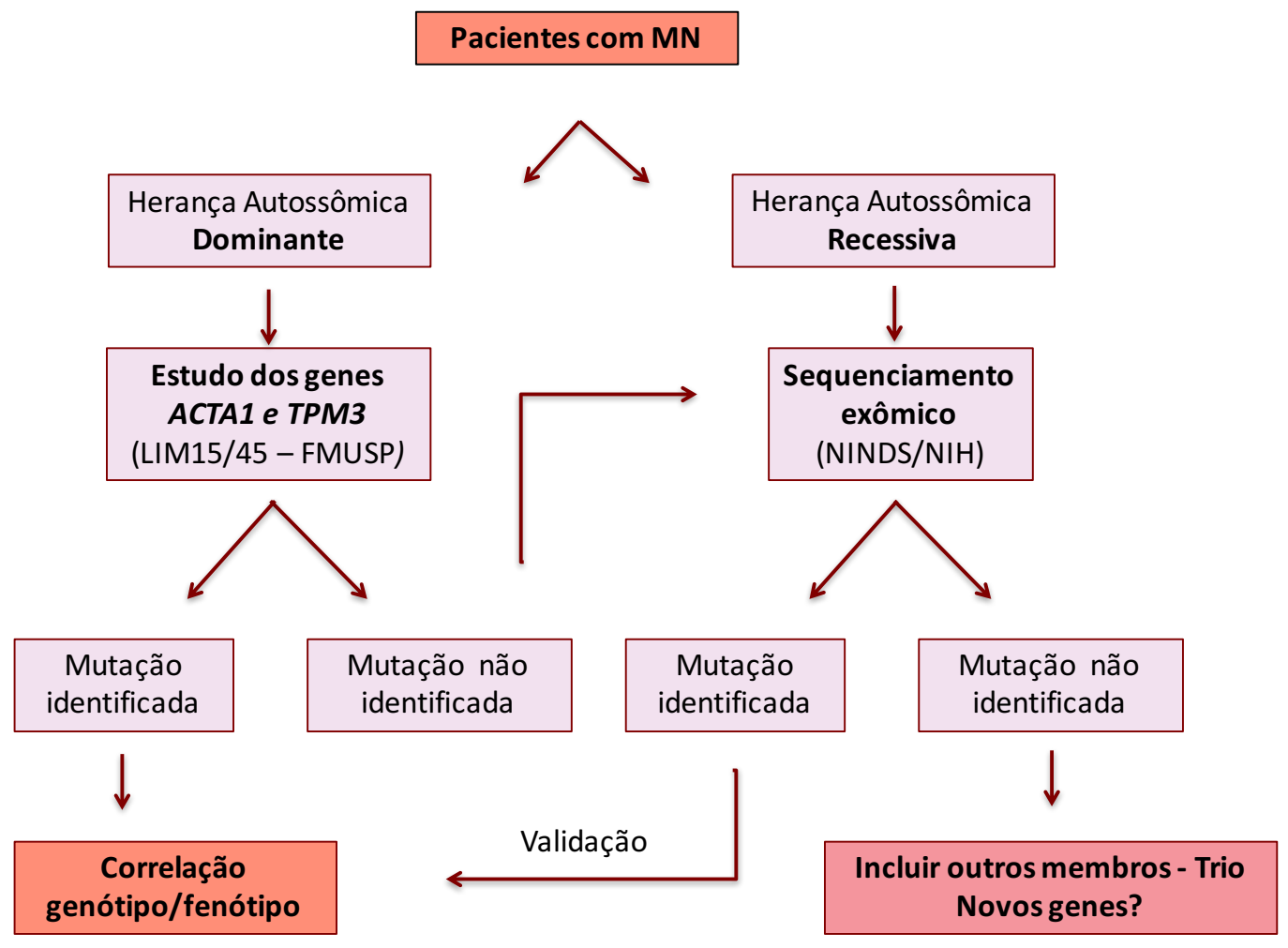


(2) Pacientes com $\mathrm{MCl}$ : foram incluídos 22 pacientes com $\mathrm{MCl}$ pertencentes a 20 famílias. Na tentativa de estratificar o estudo genético de uma maneira mais uniforme em um grupo tão variado, os pacientes foram divididos em 3 subgrupos. Pacientes com achados leves e inespecíficos (grupo 1), pacientes com espinha rígida (grupo 2) e pacientes com quadros atípicos (grupos 3), no qual incluímos os pacientes com achados clínicos proeminentes como deformidades osteoesqueléticas, oftalmoparesia e envolvimento oculofacial.

No grupo 1 (famílias $21,31,32,33,34$ e 37 ) - diagrama 2: foi realizado o sequenciamento dos exons codificantes do gene ACTA1 e dos exons 2-10 do gene TPM3. Deste grupo apenas 4 seguiram para o SE.

No grupo 2 (famílias 22, 23, 24, 25, 26, 27, 29, e 30) - diagrama 2: foi realizado o sequenciamento dos 13 exons codificantes do gene SEPN1. Como não foram encontradas mutações neste gene para este grupo de pacientes, o DNA de um paciente de cada família foi enviado para o SE.

No grupo 3 (famílias 28, 35, 36, 38, 39 e 40) - diagrama 3: foram utilizadas apenas técnicas de NGS. Nas famílias 28 e 40 foi optado pelo painel de doenças musculares, enquanto que nas famílias 35,36 e 39 foi optado pelo SE. A escolha do tipo de sequenciamento utilizado nesta situação foi em decorrência da disponibilidade do serviço no momento do estudo. O SE do paciente 38.1 encontrou uma mutação 
no exon 34 do gene MYH7. Por causa da semelhança fenotípica deste paciente com o 39.1, foi realizado o estudo deste exon por sequenciamento convencional na família 39. 
Diagrama 2 - Esquema do estudo genético dos pacientes com $\mathrm{MCl}$ sem espinha rígida (grupo 1) e com espinha rígida (grupo 2) mostrando o local onde cada etapa foi realizada.

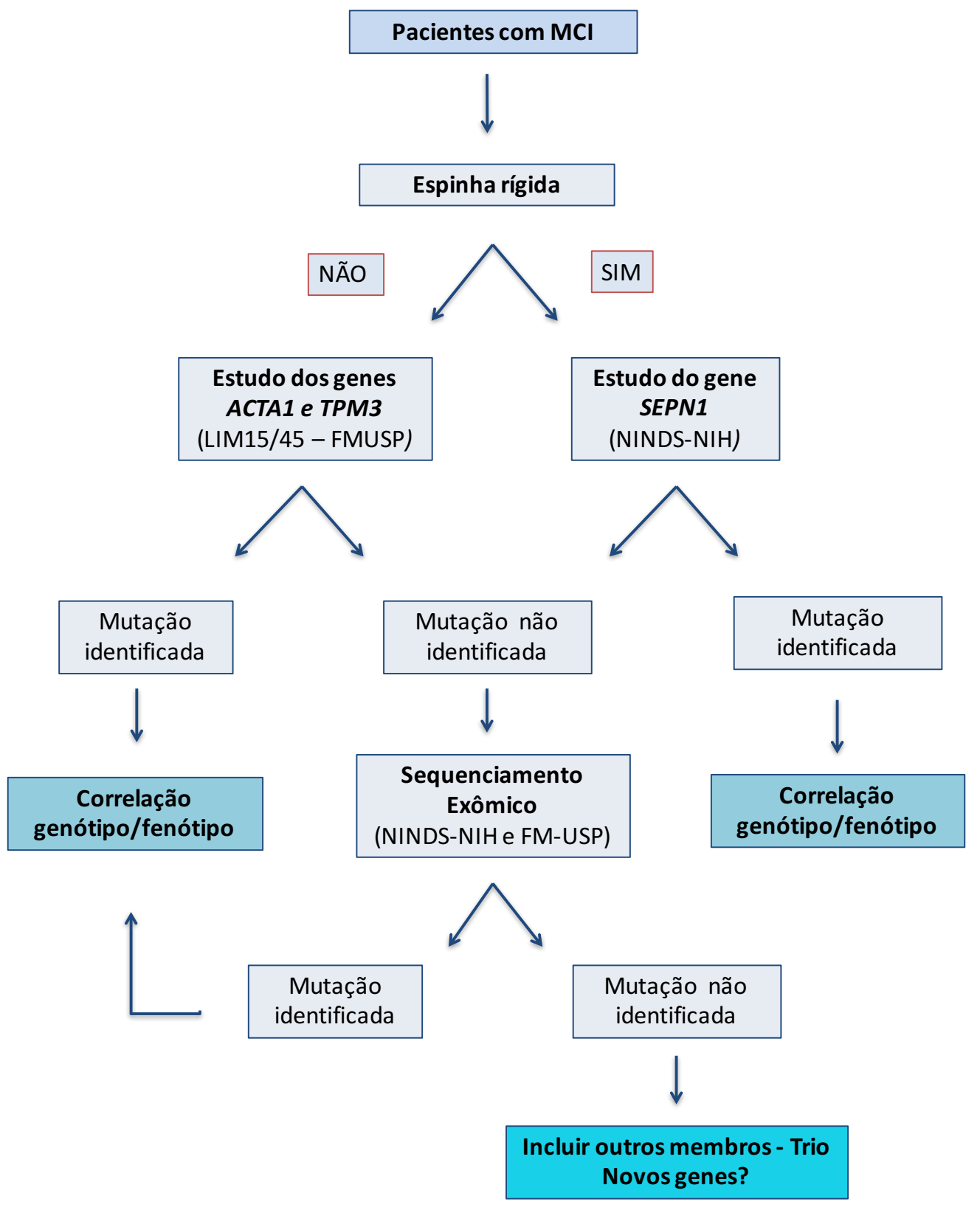


Diagrama 3 - Esquema do estudo genético dos pacientes com $\mathrm{MCl}$ com achados clínicos atípicos (grupo 3).

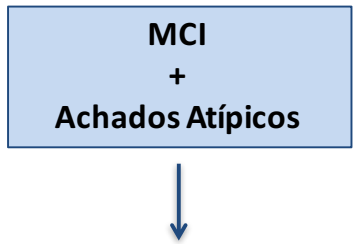

Sequenciamento Exômico/ painel de doenças musculares (NINDS-NIH e FM-USP)

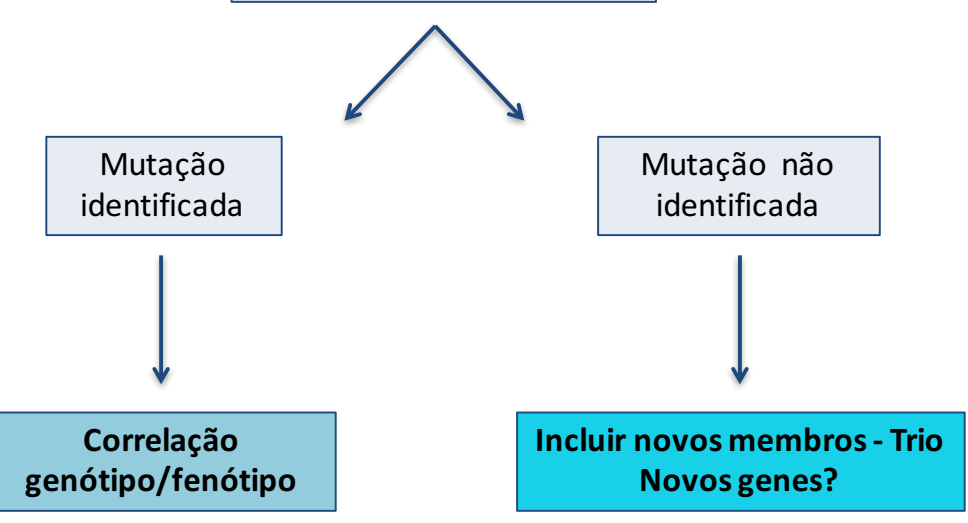




\section{RESULTADOS}

Na divisão de neurologia do HC-FMUSP, no período 1974 a 2015, foram identificados 21 pacientes com MN e 25 pacientes com MCl. No departamento de neurologia da UNIFESP, no período 1987 a 2015 foram identificados 28 pacientes com $\mathrm{MN}$ e 13 pacientes com $\mathrm{MCl}$. A partir destes, 45 pacientes, pertencentes a 40 famílias ( $20 \mathrm{com} \mathrm{MN}$ e $20 \mathrm{com} \mathrm{MCl}$ ), foram contactados e aceitaram participar do estudo.

\subsection{Descrição clínica e histológica dos pacientes com MN}

\subsubsection{Aspectos gerais}

Foram avaliados 23 pacientes pertencentes a 20 famílias com diagnóstico de $\mathrm{MN}$, sendo oito do sexo feminino e 15 do sexo masculino. A idade dos pacientes na data da avaliação variou entre sete e 46 anos.

Consanguinidade foi relatada em duas famílias (famílias 3 e 15), sendo uma delas com dois irmãos afetados. Além destes, história familiar positiva para doença muscular foi relatada em outras três famílias (família 1 e 16). Para melhor visualização dos dados, os heredogramas das famílias com MN estão na figura 4.

\subsubsection{Evolução clínica}

As formas clínicas de MN encontradas nesta coorte foram: (1) forma infantil intermediária em um paciente, (2) forma típica em 21 pacientes e (3) 
forma infantil tardia em um paciente. Para a melhor visualização dos dados, os resultados referentes aos achados clínicos e evolução clínica dos pacientes com MN estão dispostos nas tabelas 3 e 4 e ilustrados nos gráficos 1 e 2 e na figura 2.

\subsubsection{Aspectos gestacionais e perinatais:}

Quanto aos aspectos gestacionais, a diminuição da movimentação intrauterina foi relatada em apenas dois pacientes, no entanto onze pacientes apresentaram complicações neonatais.

As manifestações clínicas iniciais mais frequentemente apresentadas foram: hipotonia neonatal, dificuldade para sugar, infecções respiratórias neonatais e um importante atraso na aquisição dos marcos motores. A maioria dos quadros de infecção respiratória nos primeiros meses de vida foram atribuídos a dificuldade de sugar, engasgos e provável aspiração de alimentos.

A maioria dos pacientes teve alta com menos de 72h após o nascimento, no entanto, cinco tiveram intercorrências graves necessitando de internação em UTI, suporte ventilatório e alimentação via sonda. Um destes pacientes teve alta com menos de uma semana de internação, três ficaram internados entre 7 a 21 dias e um ficou internado por mais de 30 dias. Gastrostomia foi realizada precocemente em 3 pacientes, sendo que em dois destes foi mantida até a data da avaliação. Traqueostomia foi realizada no período neonatal em apenas 1 paciente. 


\subsubsection{Desenvolvimento}

$\mathrm{O}$ atraso dos marcos motores foi marcante e relatado em 21 pacientes. $\mathrm{O}$ sustento cefálico foi normal (obtido antes dos 3 meses) em dois pacientes, entre três e seis meses em sete, entre seis e 12 meses em nove e após os 12 meses em 5 pacientes. Nenhum paciente engatinhou. Todos os pacientes adquiriram marcha, sendo em menos de 15 meses dois pacientes, entre 15 e 24 meses em oito e após os 24 meses em 13. A paciente com forma de apresentação tardia não tem as informações relativas a todos os seus marcos motores, mas referiu que foi normal, portanto foi considerado sustento cervical menor que três meses e marcha antes dos 15 meses. Quedas da própria altura frequentes nos primeiros anos de vida e dificuldade em se levantar do chão foram apontadas em todos os pacientes.

\subsubsection{Evolução}

Todos os pacientes evoluíram com ganhos motores na primeira década. Piora funcional foi relatada na adolescência na maioria dos pacientes e foi relacionada principalmente com o aparecimento de deformidades osteoesqueléticas e problemas respiratórios. O quadro motor apresentou uma tendência a estabilidade após a adolescência. Apesar disso, em quatro pacientes foi observada piora lentamente progressiva das retrações e da fraqueza muscular resultando em limitação funcional importante e perda da marcha, que ocorreu entre primeira e segunda década. Na data da avaliação, seis pacientes conseguiam deambular até 100 metros, nove entre 100 e 1000m e quatro pacientes referiam não ter limitação para deambular no plano. Quinze 
pacientes referiam conseguir subir degraus apenas com apoio uni ou bilateral enquanto que quatro conseguiam subir degraus sem apoio.

Infecções respiratórias de repetição e dificuldade em ganhar peso foram relatados em todos os pacientes, a maioria deles evoluiu com melhora após os dois anos de vida, no entanto, nove pacientes ainda apresentavam mais de 3 episódios de infecção respiratória ao ano. Não foram realizadas avaliações de deglutição sistematizadas nos pacientes da coorte, mas foi observado que engasgos frequentes e dificuldade para ganhar peso foram observados em sete pacientes e 16 pacientes relataram que demoram mais que 30 minutos em cada refeição.

\subsubsection{Exame clínico}

Os principais achados no exame clínico dos pacientes com $\mathrm{MN}$ na data da avaliação foram: face com aspecto miopático (aspecto alongado, hipomimia facial e boca entreaberta com eversão do lábio inferior), fraqueza muscular e deformidades osteoesqueléticas. Envolvimento cognitivo não foi observado em nenhum paciente. Para a melhor visualização, os achados do exame clínico estão dispostos nas tabelas 3 e 4 e ilustrados na figura 2 e nos gráficos 1 e 2 .

Palato ogival, paresia facial e face miopática foram observados em 22 pacientes em variados graus de envolvimento. Ptose palpebral foi observada em 13 pacientes e apenas um deles apresentou oftalmoparesia. Fraqueza muscular foi observada em todos os pacientes, sendo de predomínio proximal com importante envolvimento da musculatura axial em 22 pacientes. Fraqueza da musculatura flexora do pescoço foi observada em todos os pacientes com grau 
de acometimento variável, 19 apresentaram envolvimento distal nos membros inferiores e cinco nos membros superiores. Quanto aos grais de fraqueza muscular, foi utilizado o MRC para todos os grupamentos musculares e foi considerada fraqueza leve aquela com MRC maior/igual a IV, moderada entre IV- e III, e grave abaixo de III. Ao analisar separadamente os grupamentos musculares, conforme pode ser analisado no gráfico fraqueza grave foi encontrada nos músculos flexores cervicais em 12 pacientes, abdutores do ombro em cinco, extensores do antebraço em três, extensores do punho em um, extensores da coxa em dois pacientes, flexores da coxa em oito e extensores dos pés em sete. Músculos adutores e abdutores do quadril, flexores e extensores da perna e flexores do antebraço e do punho não foram gravemente acometidos nessa coorte.

O aparecimento de deformidades osteoesqueléticas ainda na primeira década de vida foi observado na maioria dos casos, sendo as principais: cifoescoliose e deformidade torácica. Estas deformidades foram determinantes no comprometimento respiratório, que também se mostrou grave e precoce na maioria dos pacientes e ainda, desproporcional ao grau de fraqueza apendicular. Apenas seis pacientes apresentaram retrações tendíneas, seis apresentaram hiperelasticidade distal e três apresentaram espinha rígida toracolombar ao exame físico, definida como restrição a flexão e rotação de tronco. 


\subsubsection{Exames complementares e biópsia muscular}

\subsubsection{Exames complementares}

Os exames complementares estão demonstrados na tabela 5 e no gráfico 3. A enzima $\mathrm{CPK}$ estava normal em todos os pacientes. Eletroneuromiografia foi realizada em quase todos os pacientes no início da investigação e todos eles apresentaram padrão miopático. O paciente 20.1 havia realizado mais de uma EMNG, sendo a primeira neurogênica e a segunda, miopática.

Com relação a prova de função respiratória, pacientes com capacidade vital forçada (CVF) inferior a 40 foram classificados com distúrbio ventilatório restritivo grave, moderado com valores entre 40 e 60, leve com valores entre 60 e 80. Valores de CVF superior a 80 são considerados normais, mas não afastam completamente a presença de distúrbio ventilatório, por este motivo foi solicitado polissonografia para alguns pacientes. Isto possibilita afastar distúrbios ventilatórios precoces que cursam apenas com hipercarbia noturna, aumento do índice de apnéia e hipopnéia e dessaturação de oxigênio durante o sono.

A realização da espirometria não foi adequada em alguns pacientes. Em decorrência da fraqueza da musculatura facial, alguns pacientes não conseguiram executar o teste e não haviam dispositivos adaptados para esta situação no nosso serviço. No entanto, distúrbio ventilatório grave foi encontrado em doze pacientes, sendo que destes, seis faziam uso de suporte ventilatório não invasivo tipo binível apenas durante o sono e três utilizavam o aparelho ao longo de todo o dia, com períodos de uso variados. Distúrbio ventilatório restritivo moderado foi encontrado em seis pacientes e leve foi encontrado em quatro. 
Apenas um paciente apresentou função respiratória normal. Os exames cardiológicos foram normais na maioria dos pacientes e cardiopatia foi observada apenas em uma paciente desta coorte, mas foi considerada secundária ao distúrbio respiratório.

\subsubsection{Biópsia muscular}

Os achados histológicos foram variados e estão demonstrados no gráfico 4 e ilustrados na figura 3. Aumento na variabilidade do tamanho das fibras foi observado em 18 pacientes, sendo discreto em sua maioria. Aumento de centralizações foi observada em apenas um paciente. A maioria dos pacientes apresentou predomínio e atrofia de fibras tipo 1, sendo que predomínio total de fibras tipo 1 foi observado em cinco pacientes.

A quantidade e localização dos bastões nemalínicos foi variada entre os pacientes e não observamos nenhuma correlação da quantidade de bastões com a clínica do paciente. Os bastões foram encontrados em $100 \%$ das fibras em dezesseis pacientes. Quanto a sua localização, o predomínio foi subsarcolemal em quatroze e em onze pacientes estavam distribuídos difusamente pelo citoplasma. Um paciente apresentou atrofia de fibras tipo $1 \mathrm{e}$ presença de bastões exclusivamente nestas fibras. Massas citoplasmáticas foram detectadas em dois pacientes, sendo que em um deles foi detectado também bastões intranucleares. 


\subsubsection{Reabilitação e escolaridade}

No acompanhamento destes pacientes foi observado que a MN se trata de uma doença com importantes aspectos sociais. Conforme pode ser observado no gráfico 5 , apenas onze pacientes faziam fisioterapia motora e oito faziam fisioterapia respiratória ao menos uma vez por semana, sendo que esta foi solicitada de maneira contínua para todos os pacientes. Apesar das queixas fonoaudiológicas serem tão frequentes, apenas sete pacientes seguem em acompanhamento fonoterápico.

Não foi observado envolvimento cognitivo em nenhum paciente e 21 deles referiram bom desenvolvimento escolar. Apesar disso seis pacientes tiveram algum atraso nos estudos, dois abandonaram os estudos ainda no ensino fundamental e três no ensino médio. 


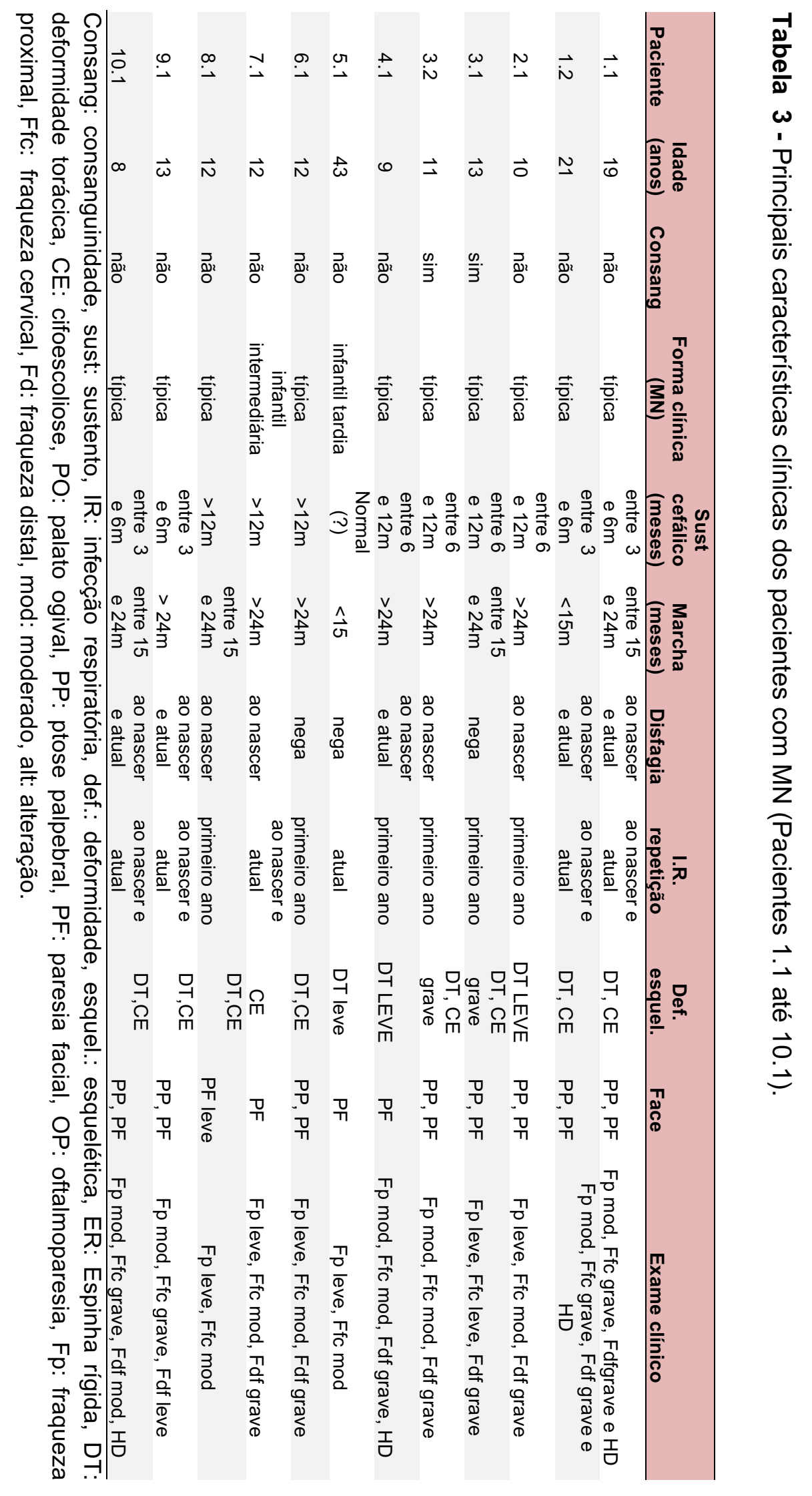




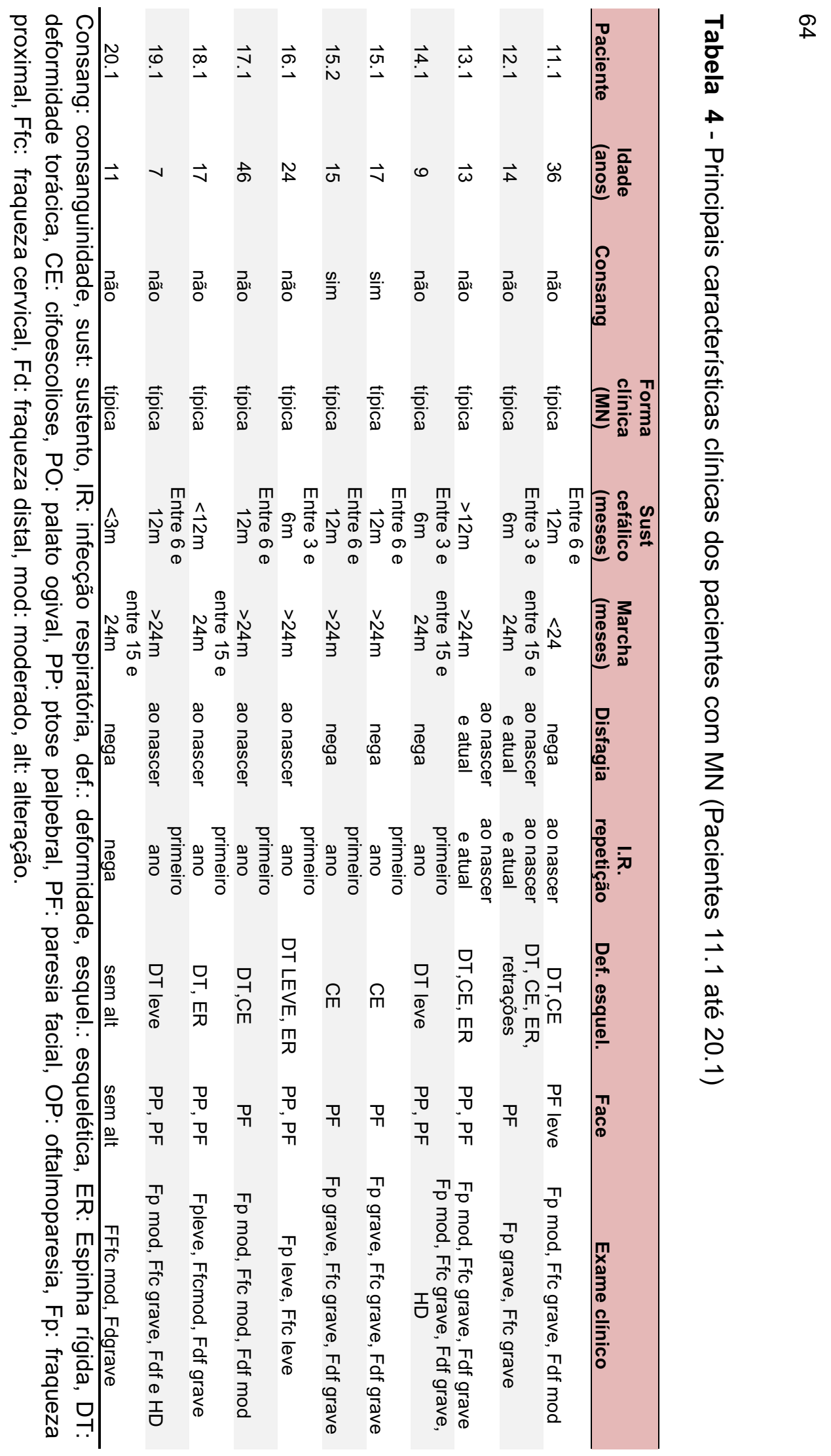


Tabela 5 - Exames complementares dos pacientes com MN.

\begin{tabular}{|c|c|c|c|c|c|}
\hline Paciente & Função pulmonar & Ecocardiograma & ECG & CPK & ENMG \\
\hline 1.1 & $C V F<40$ & normal & normal & normal & miopática \\
\hline 1.2 & $C V F<40$ & normal & normal & normal & não realizou \\
\hline 2.1 & CVF $>60$ & normal & normal & normal & miopática \\
\hline 3.1 & $C V F<40$ & normal & normal & normal & miopática \\
\hline 3.2 & $\mathrm{CVF}<40$ & normal & normal & normal & não realizou \\
\hline 4.1 & $C V F<40$ & normal & normal & normal & miopática \\
\hline 5.1 & CVF $<40$ & Hipertensão pulmonar & normal & normal & miopática \\
\hline 6.1 & CVF $>60$ & normal & normal & normal & miopática \\
\hline 7.1 & CVF $<40$ & normal & normal & normal & miopática \\
\hline 8.1 & CVF>60 & normal & normal & normal & miopática \\
\hline 9.1 & $C V F<40$ & normal & normal & normal & miopática \\
\hline 10.1 & CVF41-60 & normal & normal & normal & miopática \\
\hline 11.1 & CVF $<40$ & normal & normal & normal & miopática \\
\hline 12.1 & CVF $<40$ & normal & normal & normal & miopática \\
\hline 13.1 & CVF41-60 & normal & normal & normal & miopática \\
\hline 14.1 & CVF41-60 & normal & normal & normal & miopática \\
\hline 15.1 & $C V F<40$ & normal & normal & normal & miopática \\
\hline 15.2 & CVF $<40$ & normal & normal & normal & miopática \\
\hline 16.1 & CVF41-60 & normal & normal & normal & miopática \\
\hline 17.1 & CVF41-60 & Insuf. Mitral leve & normal & normal & miopática \\
\hline 18.1 & CVF41-60 & aguarda & normal & normal & miopática \\
\hline 19.1 & CVF $>60$ & normal & normal & normal & miopática \\
\hline 20.1 & CVF $>80$ & normal & normal & normal & miopática/neuropática \\
\hline
\end{tabular}

CVF: capacidade vital forçada, ECG: eletrocardiograma, CPK: creatinofosfoquinase, ENMG: eletroneuromiografia. Insuf: insuficiência. 
Gráfico 1 - Principais características clínicas (história clínica, exame físico e queixas atuais) dos pacientes com $\mathrm{MN}(\mathrm{N}=23)$.

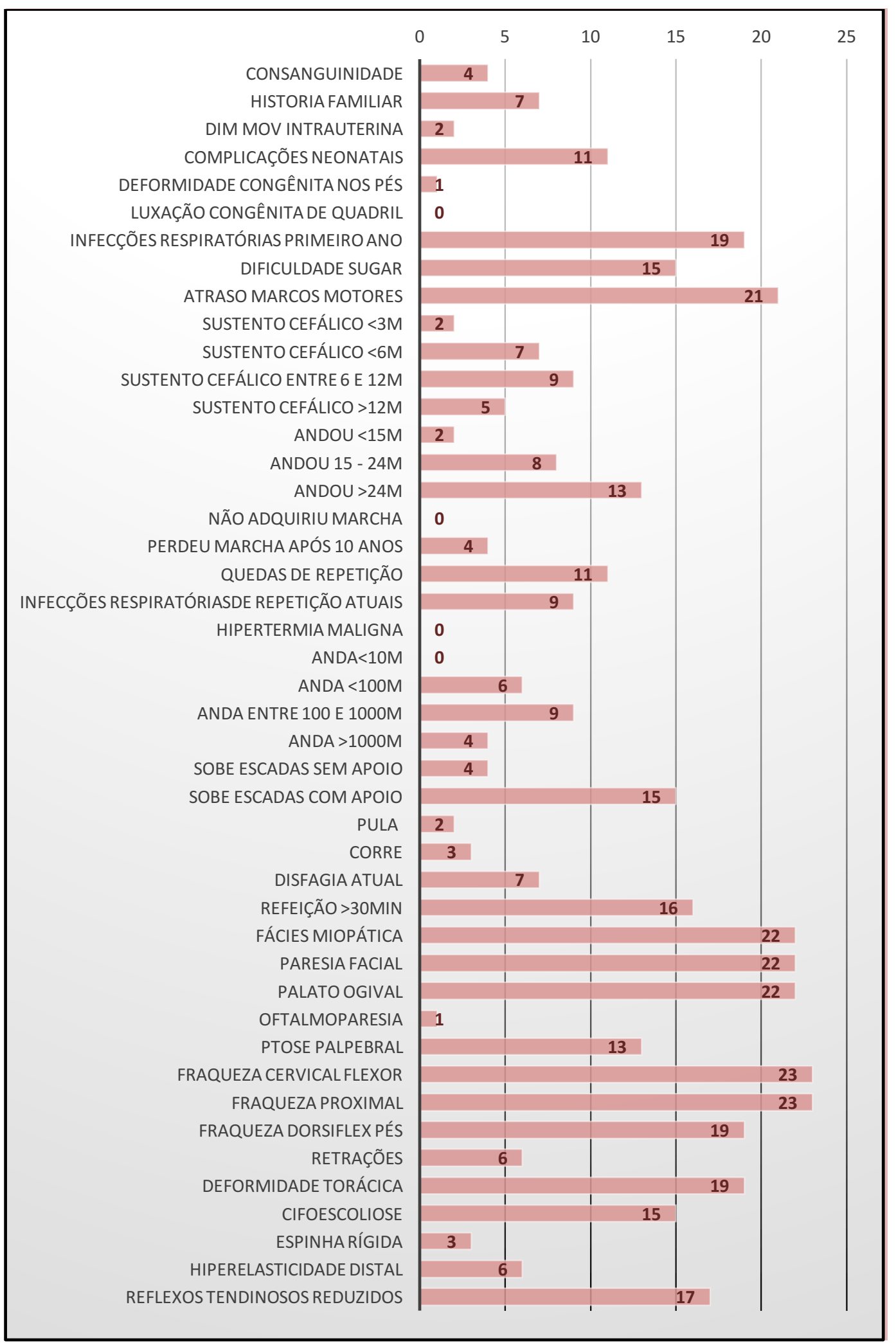


Gráfico 2 - Grupos musculares mais gravemente afetados - fraqueza muscular grave (força MRC menor/igual a III) nos pacientes com MN ( $N=23)$.

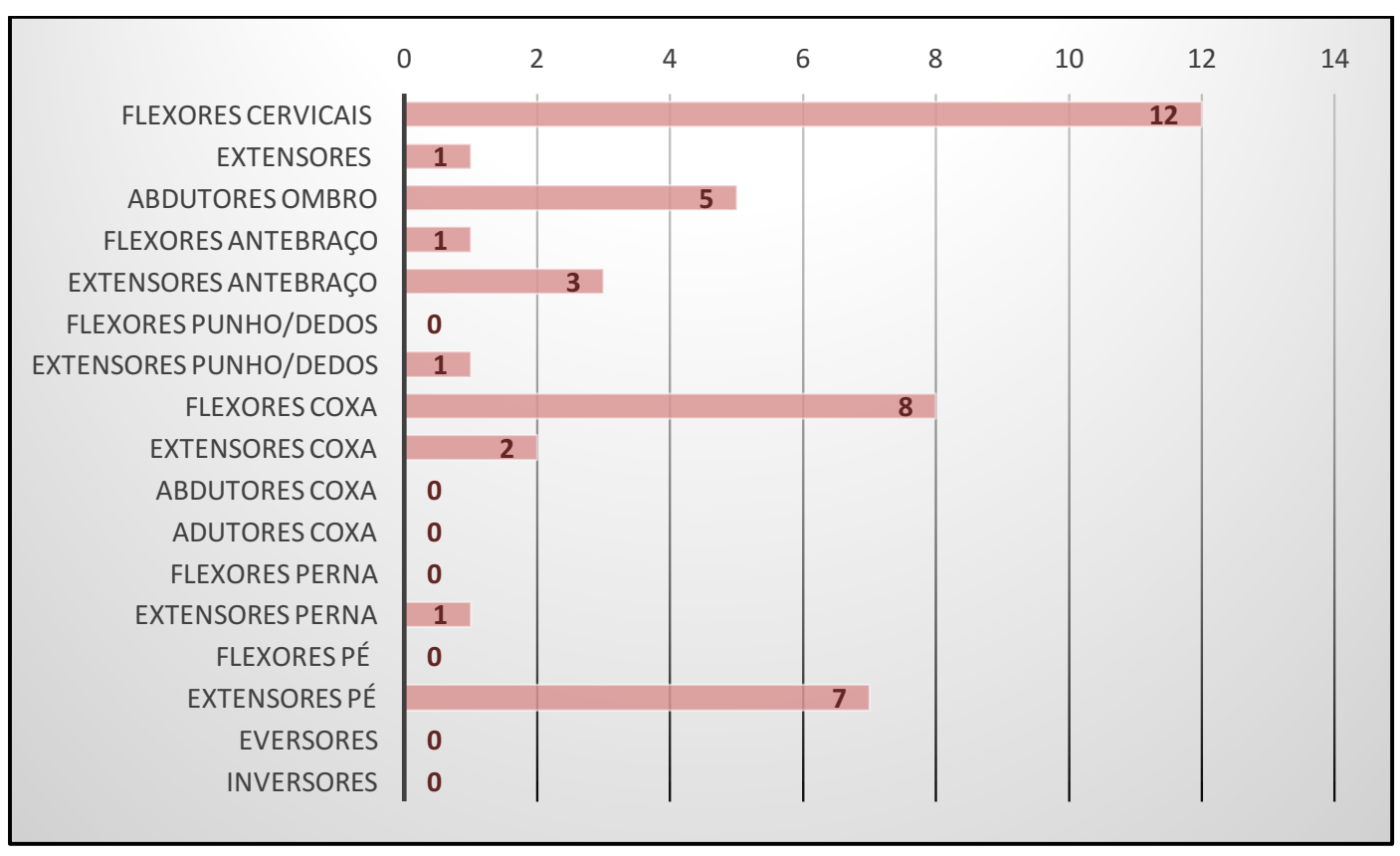


Gráfico 3 - Exames complementares dos pacientes com $\mathrm{MN}(\mathrm{N}=23)$.

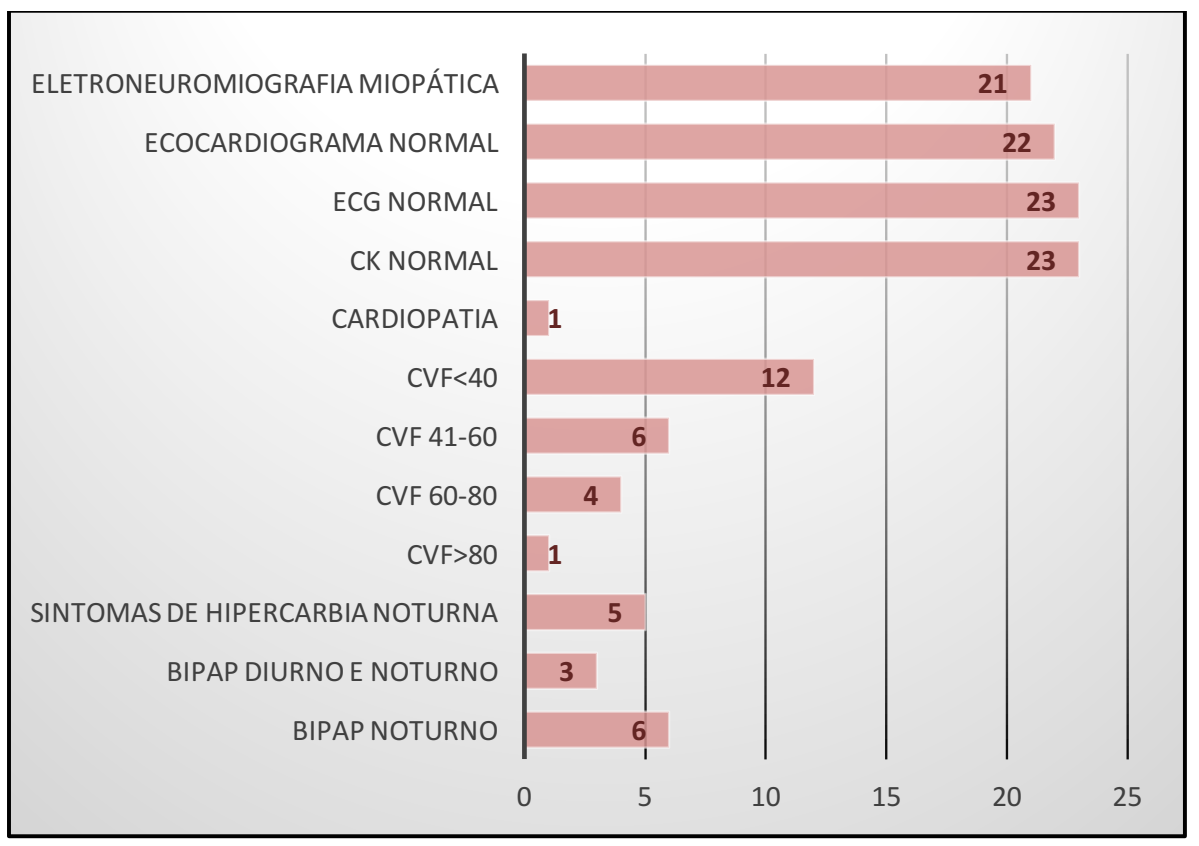

Gráfico 4 - Principais características histológicas observadas na análise da biópsia muscular dos pacientes com $\mathrm{MN}(\mathrm{N}=23)$.

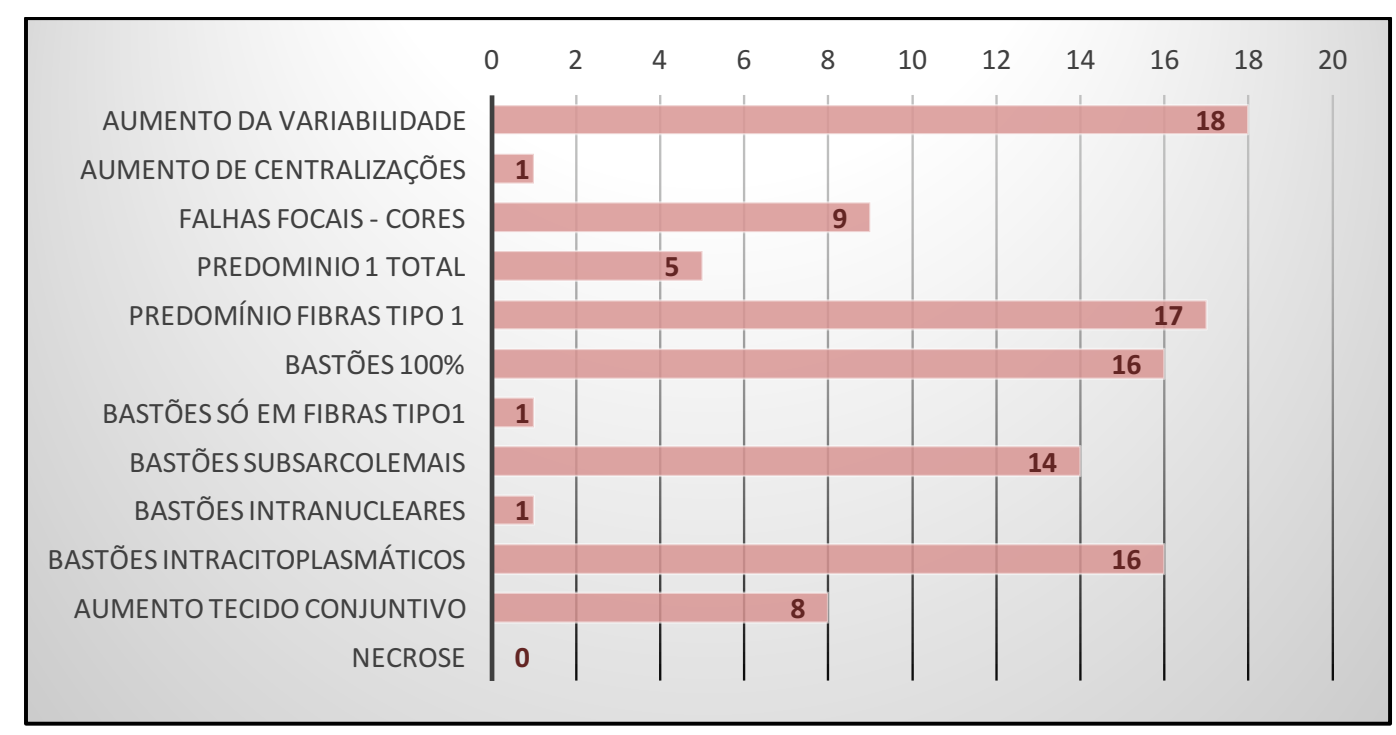


Gráfico 5 - Escolaridade e reabilitação dos pacientes com MN (N=23).

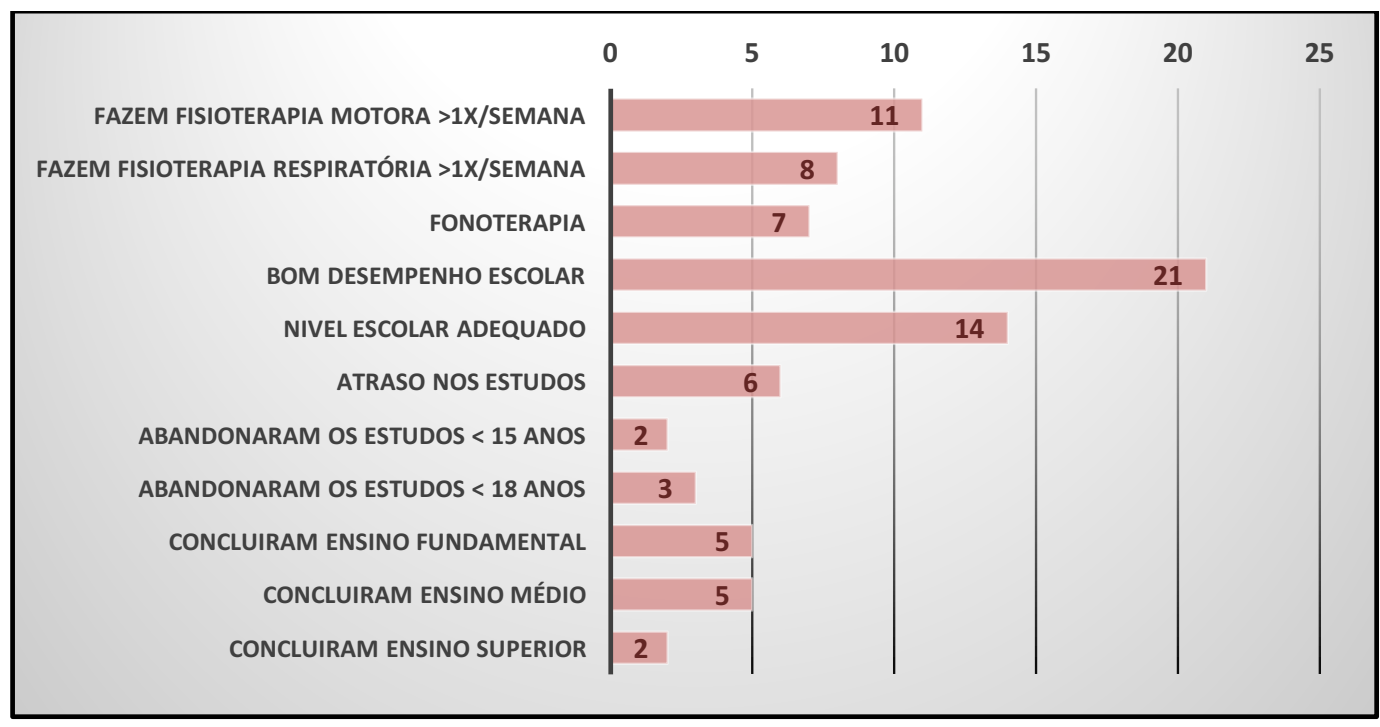



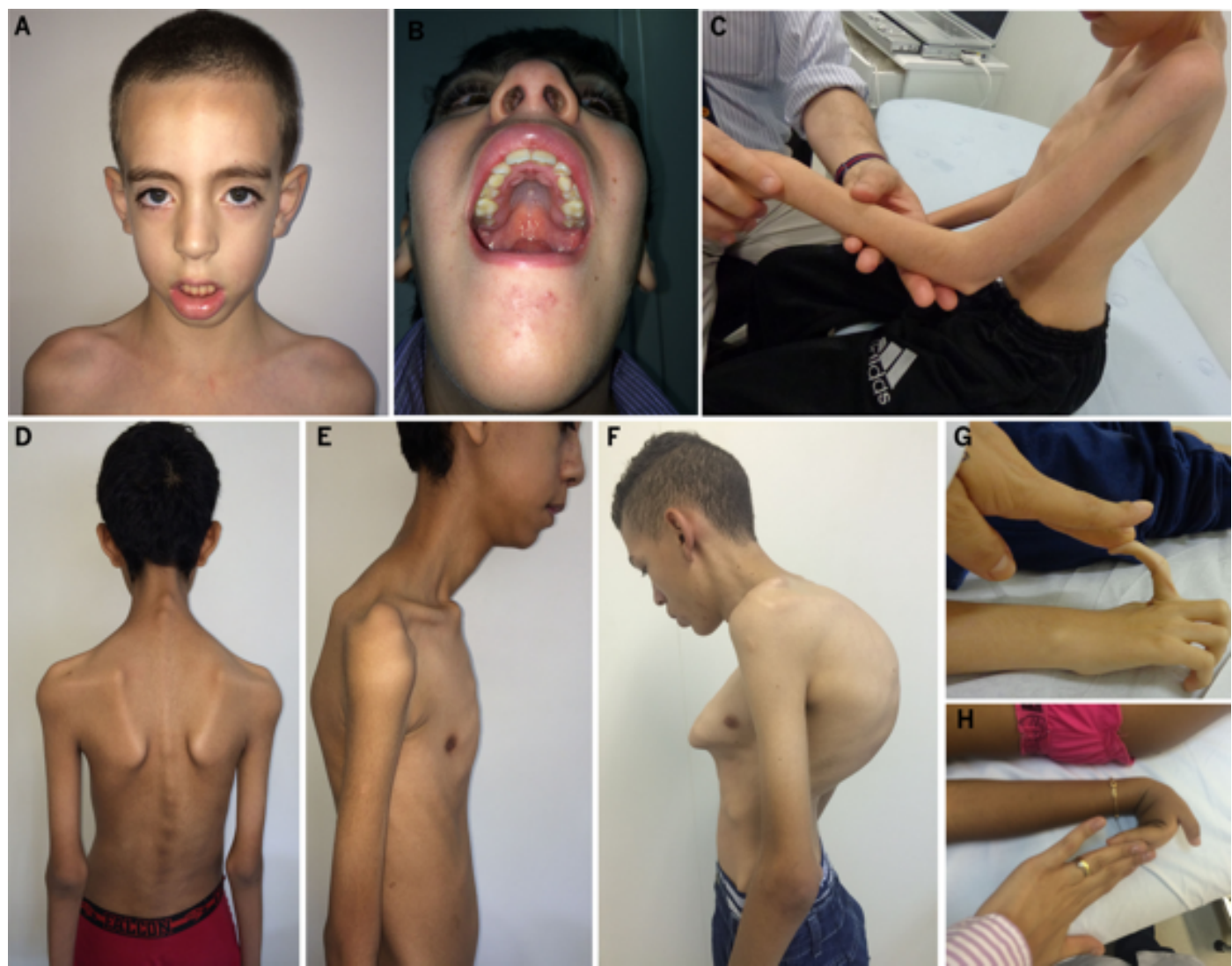

Figura 2 - Características clínicas gerais dos pacientes com MN. A: face miopática (paciente10.1). B: palato ogival (paciente 4.1). C: presença de retrações tendíneas (paciente12.1). D: cifoescoliose e escápula alada (paciente 13.1). E e F: deformidade torácica (pacientes 13.1 e 3.1 respectivamente). G e H: presença de hiperelasticidade articular distal (pacientes 12.1 e 20.1 respectivamente). 

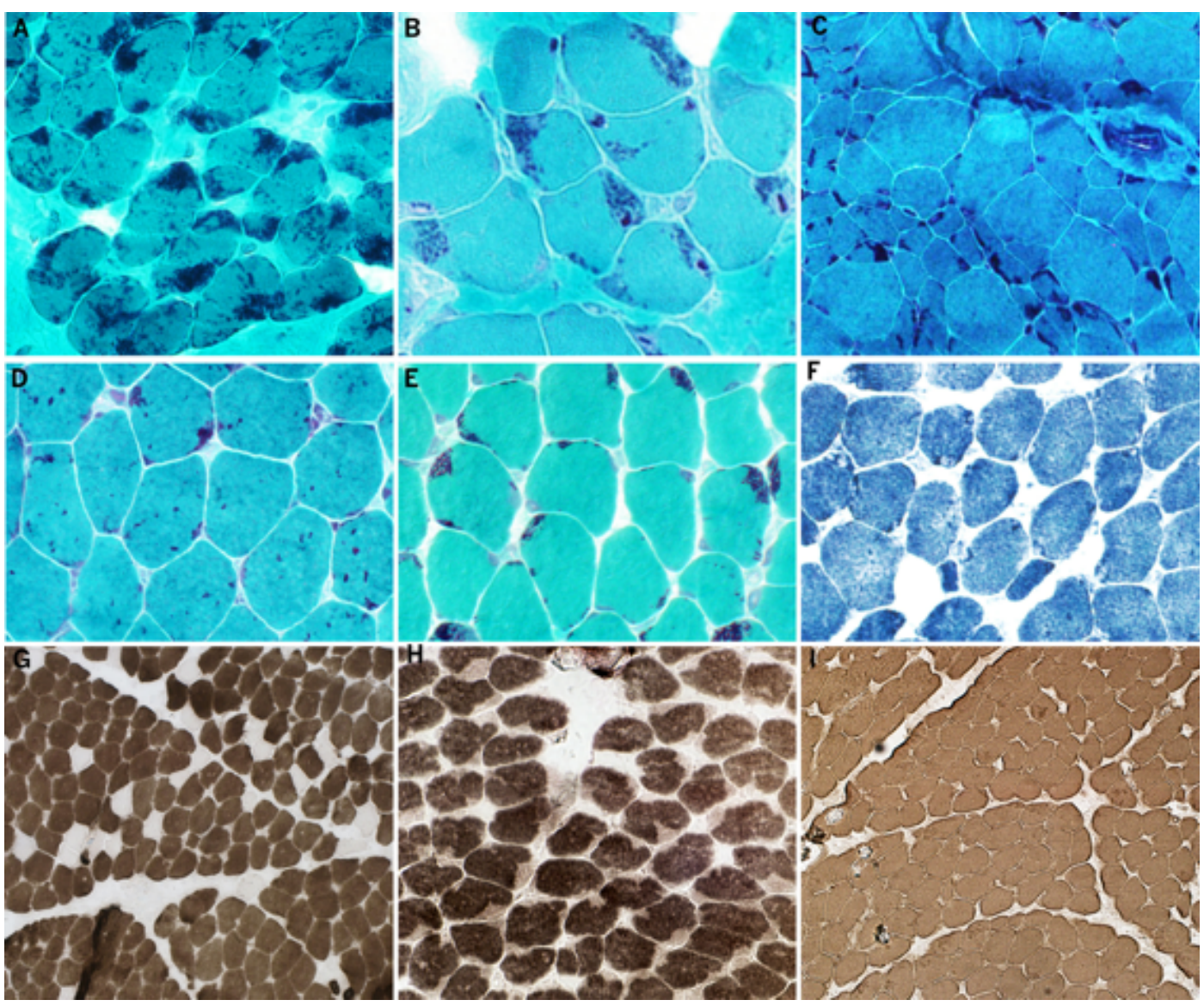

Figura 3 - Características gerais da biópsia muscular dos pacientes com MN. A: bastões em $100 \%$ das fibras com aumento do tecido conjuntivo (paciente 3.1) (GO, 40x). B: bastões localizados em região subsarcolemal e intranuclear (paciente 13.1) (GO, 40x). C: aumento da variabilidade no tamanho das fibras com presença dos bastões apenas em fibras atrofiadas (paciente 7.1) (GO, 40x). D: bastões localizados difusamente pelo citoplasma presentes em $100 \%$ das fibras, sem alterações distróficas e sem aumento da variabilidade no tamanho das fibras (paciente 10.1) (GO, 40x). E: bastões presentes na maioria das fibras, localizados apenas em região subsarcolemal (paciente 2.1) (GO, 40x). F: falhas focais de atividade oxidativa (paciente 14.1) (NADHTR, 40x). G: Predomínio de fibras tipo 1 (paciente 10.1) (ATPase 4.3, 20x). H: predomínio de fibras tipo $1 \mathrm{com}$ destituição de atividade da ATPase nas regiões dos bastões (paciente 3.1) (ATPase 4.3, 40x). I: predomínio total de fibras tipo 1 (paciente 2.1) (ATPase 4.3, 20x). 

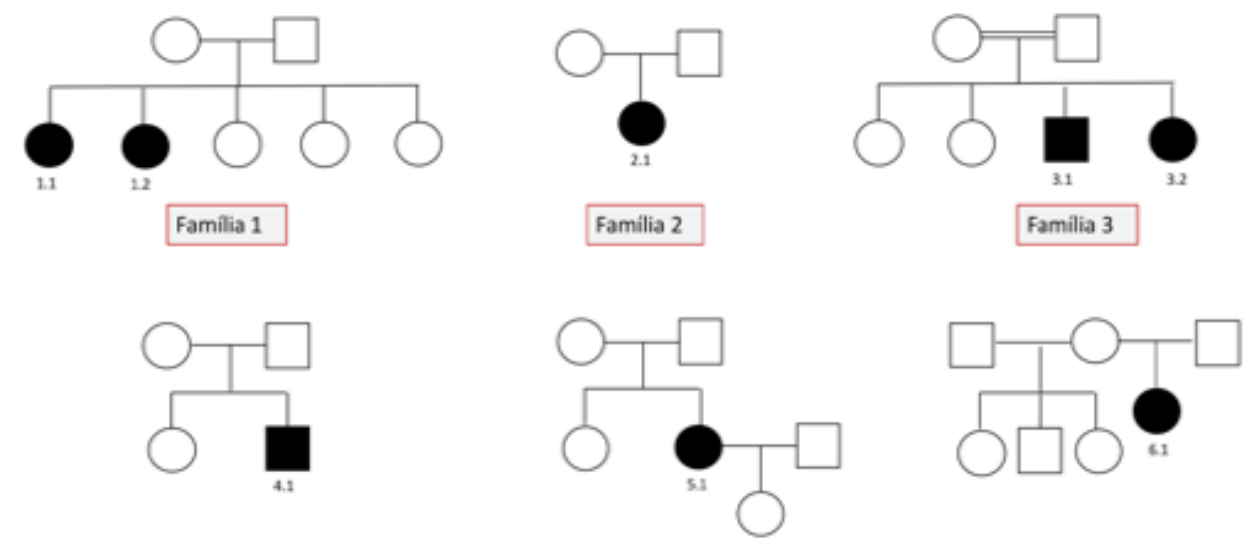

Familia 4

Familia 5

Familia 6
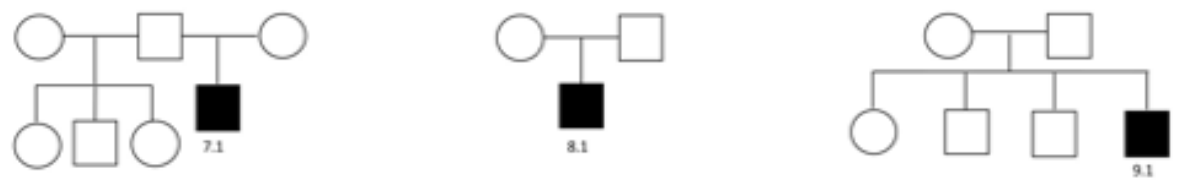

Familia 7

Familia 8

Familia 9
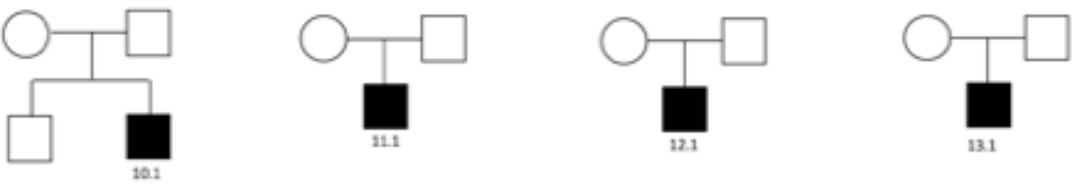

Familia 10

$$
\text { Familia } 11
$$

Familia 12

Familia 13
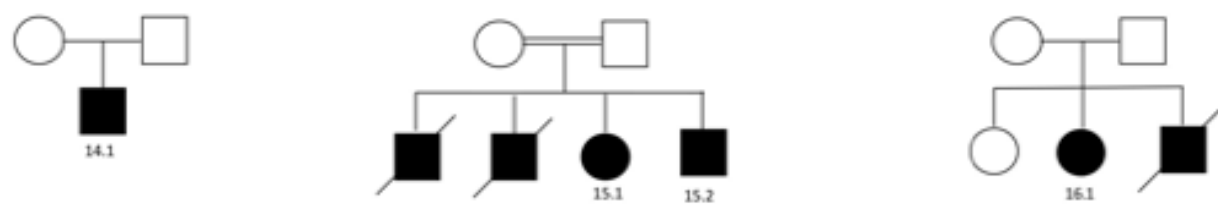

Familia 14

Familia 15

Familia 16
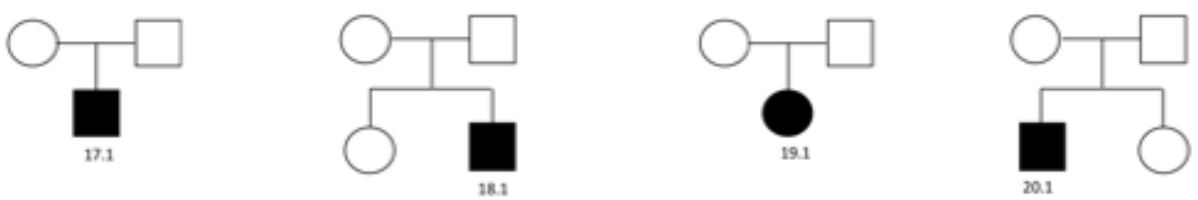

Familia 17

Familia 18

Familia 19

Familia 20

Figura 4 - Heredogramas das famílias da coorte de MN. 


\subsection{Descrição clínica e histológica dos pacientes com MCI}

\subsubsection{Aspectos gerais}

Foram avaliados 22 pacientes pertencentes a 20 famílias com miopatia com achados leves e inespecíficos $(\mathrm{MCl})$. Foram incluídos neste grupo, os pacientes quadro clínico de miopatia congênita com achados inespecíficos na biópsia muscular, sendo eles: desproporção de tipo de fibras, aumento da variabilidade do tamanho das fibras, centralizações nucleares, alterações inespecíficas na arquitetura interna das fibras musculares (falhas focais, minicores, formações core like), aumento leve do tecido conjuntivo e predomínio de fibras tipo 1.

A idade dos pacientes na primeira avaliação variou de quatro a 35 anos; e a idade dos pacientes em que foi feita a biópsia variou de um a 15 anos. Consanguinidade foi relatada em quatro famílias e casos semelhantes na família em seis. Para melhor visualização dos dados, os heredogramas das famílias com $\mathrm{MCl}$ estão na figura 7.

\subsubsection{Evolução clínica}

O quadro clínico observado neste grupo de pacientes foi bastante variado. O início dos sintomas ocorreu no período neonatal em 16 famílias e nos primeiros anos de vida em quatro. Para a melhor visualização dos dados, os resultados referentes a evolução clínica dos pacientes com $\mathrm{MCl}$ estão dispostos nas tabelas 6 e 7 e ilustrados no gráfico 6 e na figura 5 .

\subsubsection{Aspectos gestacionais e perinatais}


Quanto aos aspectos gestacionais, a diminuição da movimentação intrauterina não foi relatada em nenhum caso. As manifestações clínicas iniciais mais comumente apresentadas foram: hipotonia neonatal, infecção respiratória e atraso na aquisição dos marcos motores. Complicações neonatais foram relatadas em 11 pacientes. Destes, apenas dois necessitaram de cuidados intensivos logo ao nascer, mas o período de internação foi inferior a dez dias. As principais complicações neonatais foram: insuficiência respiratória, infecção respiratória, dificuldade de sugar, perda de peso importante e redução de movimentos espontâneos. Nove pacientes apresentaram infecções respiratórias de repetição no primeiro ano de vida e oito não conseguiam sugar adequadamente. Um paciente da coorte (22.1) necessitou de correção para comunicação intraventricular nos primeiros anos de vida e apresentou provável quadro de hipertermia maligna durante o procedimento anestésico. Esta complicação anestésica também foi apresentada por outro paciente (29.1) desta coorte nos seus primeiros anos de vida, caracterizada por rigidez da musculatura e febre logo após o uso de anestésico inalatório. Deformidade congênita nos pés foi relatada em dois pacientes (21.1 e 35.1), sendo que um deles também apresentou luxação congênita de quadril (21.1).

\subsubsection{Desenvolvimento e evolução}

Atraso dos marcos motores foi relatado em 18 pacientes e foi o principal motivo que levou os pacientes a procurarem atendimento especializado seguido por quedas frequentes e dificuldade em se levantar do chão. O sustento cefálico foi obtido antes dos três meses em seis pacientes, entre três e seis meses em 
três e entre seis e doze meses em doze pacientes. Nenhum paciente engatinhou. Todos os pacientes adquiriram marcha, sendo antes dos 15 meses em quatro $p$, entre 15 e 24 meses em nove e após os 24 meses em oito.

A maioria dos pacientes, apesar do atraso, evoluiu com ganhos motores na primeira década, no entanto, uma piora funcional foi relatada na adolescência na maioria dos pacientes, com tendência a estabilização do quadro clínico após este período. A piora clínica foi caracterizada pelo aparecimento de deformidades osteoesqueléticas como cifoescoliose, deformidade torácica e retrações, piora da função respiratória e das queixas de fraqueza muscular. Um paciente perdeu a marcha aos 8 anos (26.1) e um aos 33 (40.1). Outros três pacientes evoluíram com piora importante do quadro de fraqueza axial com deformidades osteoesqueléticas. Dois pacientes deambulavam menos de $10 \mathrm{~m}$ e apresentaram limitações funcionais importantes com necessidade de auxilio em atividades diárias como comer, vestir, tomar banho e não subiam degraus nem com apoio bilateral, dois deambulavam entre 10 e $100 \mathrm{~m}$, quatro deambulavam entre 100 e $1000 \mathrm{~m}$ e nove referiram deambular mais que $1000 \mathrm{~m}$ até precisarem descansar. Quanto a subir degraus, seis pacientes não necessitavam de apoio, 10 pacientes necessitavam de apoio uni ou bilateral e quatro pacientes não conseguiam subir degraus. Apenas três pacientes conseguiam correr e pular no momento da avaliação.

Outras queixas comuns foram quedas frequentes, Infecções respiratórias de repetição, engasgos frequentes e dificuldade em ganhar peso, sendo todas estas mais proeminentes nos primeiros anos de vida. No entanto, na última avaliação, oito pacientes ainda mantinham a queixa de infecções respiratórias 
de repetição, oito referiam quedas de repetição, dois referiam sintomas de disfagia e outros demoravam mais de 30min em cada refeição.

\subsubsection{Exame clínico}

Os principais achados no exame clínico dos pacientes com $\mathrm{MCl}$ na data da avaliação estão dispostos nas tabelas 6 e 7, gráfico 6 e na figura 5 . Os achados mais encontrados foram: fraqueza muscular e deformidades osteoesqueléticas. Envolvimento cognitivo não foi observado em nenhum paciente.

Envolvimento facial foi observado na maioria dos pacientes, face miopática foi observada em 15 pacientes, palato ogival em 17 e ptose palpebral em 10 pacientes, dos quais apenas três com oftalmoparesia.

Fraqueza muscular foi observada em todos os pacientes, sendo de predomínio proximal em 18 pacientes. Fraqueza da musculatura flexora do pescoço foi observada em 16 pacientes, sendo moderada a grave em 11, envolvimento distal nos membros inferiores em cinco pacientes e distal nos membros superiores em três pacientes.

A maioria dos pacientes evoluiu com deformidades osteoesqueléticas ainda na primeira década de vida, sendo as principais: cifoescoliose e deformidade torácica. Espinha rígida foi observada em oito pacientes e foi definida como limitação para a flexão e rotação do tronco e ainda por presença de rigidez a palpação na musculatura paraespinhal. Estes pacientes apresentaram um maior comprometimento da musculatura axial e respiratória. 
Oito pacientes apresentaram retrações tendíneas, sendo graves em apenas um paciente e onze apresentaram cifoescoliose, sendo que três foram submetidos a correção cirúrgica antes dos 15 anos de idade e um aos 20 anos. Todos os quatro pacientes submetidos a correção cirúrgica apresentaram melhora e/ou estabilização do distúrbio ventilatório.

\subsubsection{Exames complementares e biópsia muscular}

\subsubsection{Exames complementares}

Os exames complementares dos pacientes podem ser visualizados na tabela 8 e no gráfico 7. Alguns pacientes não possuiam todos os exames. A espirometria não foi solicitada para pacientes com menos de seis anos pela dificuldade técnica do exame. A enzima CPK estava normal em todos os pacientes. Distúrbio ventilatório restritivo foi encontrado em 13 pacientes, sendo leve em seis, moderado em quatro e grave em três, os quais fazem uso de suporte ventilatório não invasivo tipo binível. Cardiopatia relacionada a doença muscular não foi observada nesta coorte.

\subsubsection{Biópsia muscular}

Biópsia muscular foi realizada em algum momento da investigação em pelo menos um indivíduo de cada família. Não foi realizada nos pacientes 36.2 e 39.2 . 
Os achados histológicos foram variados e estão ilustrados no gráfico 8 e na figura 6. As fibras musculares eram atrofiadas com aspecto arredondado em sete pacientes. Aumento de centralizações nucleares foi detectado em três pacientes e fibras em necrose em apenas um. Aumento na variabilidade do tamanho das fibras foi observado em 18 pacientes. Quanto ao tipo de fibras, predomínio e/ou atrofia de fibras tipo 1 foram encontradas em dez pacientes, sete apresentavam apenas predomínio de fibras tipo 1, um paciente apresentou predomínio total de fibras tipo 2 e um paciente apresentou atrofia de fibras tipo 2. Falhas focais de atividade oxidativa foram detectadas em oito pacientes. Agregados proteicos não foram observados em nenhum dos casos.

\subsubsection{Reabilitação e escolaridade}

Conforme pode ser observado no gráfico $\mathbf{9}$, a reabilitação dos pacientes com $\mathrm{MCl}$ foi mantida apenas na minoria dos casos. Apenas oito pacientes faziam fisioterapia motora ao menos uma vez por semana, enquanto que, dos 13 pacientes que apresentavam distúrbio ventilatório restritivo, apenas cinco faziam fisioterapia respiratória. Dois pacientes seguiam em acompanhamento fonoterápico.

Não foi observado envolvimento cognitivo em nenhum paciente, apenas uma paciente apresentou atraso na linguagem, mas fazia acompanhamento para disfonia. Exceto um paciente, todos os outros referiram bom desempenho escolar, mas quatro pacientes abandonaram os estudos e relacionaram este fato a dificuldade motora. Apenas dois de cinco pacientes com mais de 20 anos de 
idade haviam concluído ou estavam concluindo o ensino superior e estavam inseridos no mercado de trabalho. 


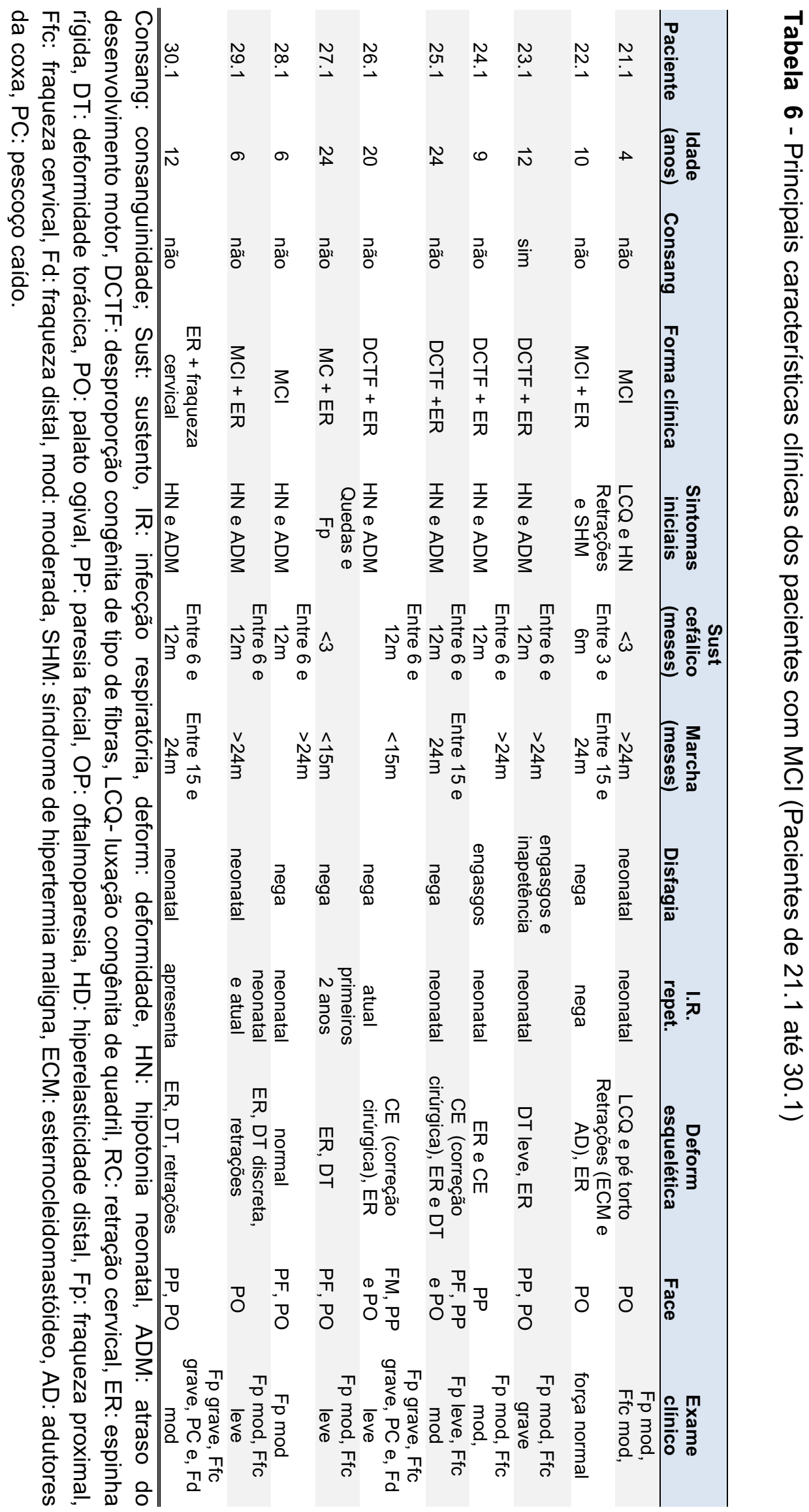




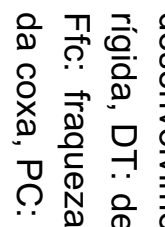

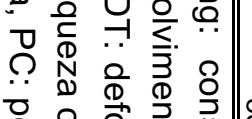

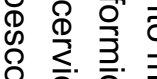

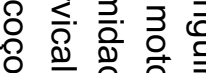

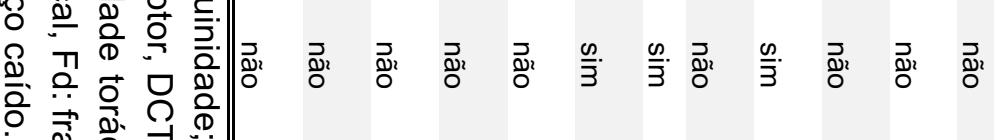

ڤำ ำ

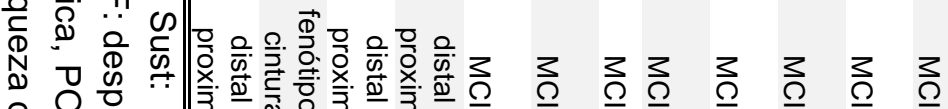

응

$\underline{\underline{D}} \stackrel{0}{\underline{D}}$ 응

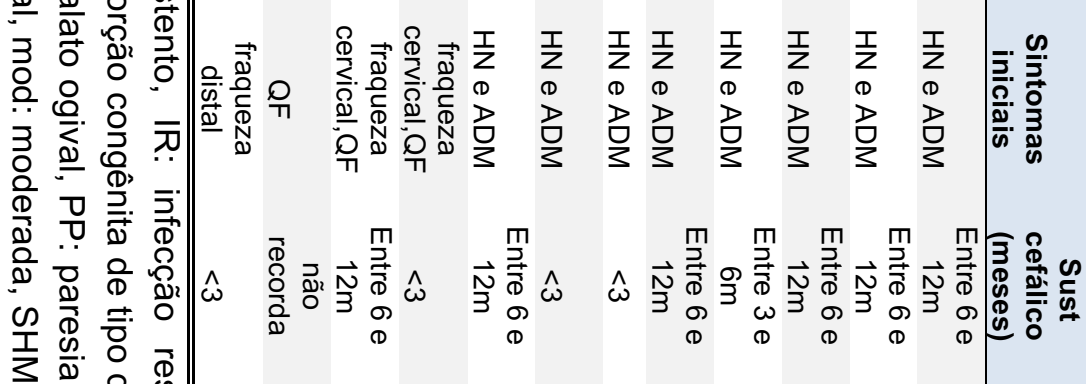

公.

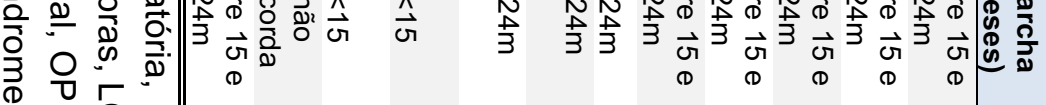

离

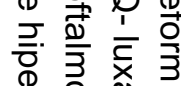

垔

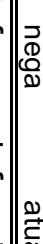

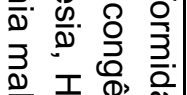

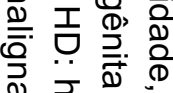

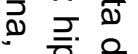

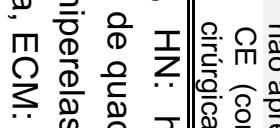

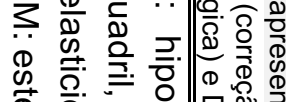

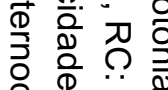

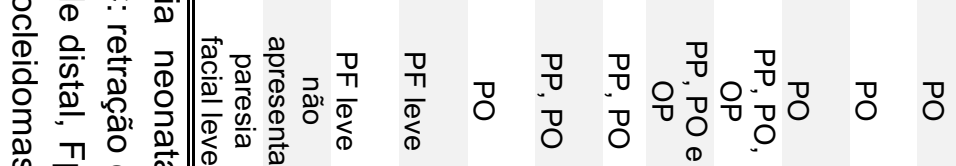

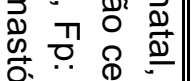

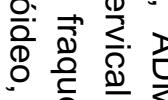

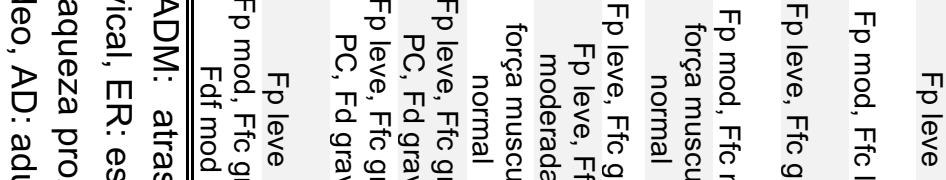

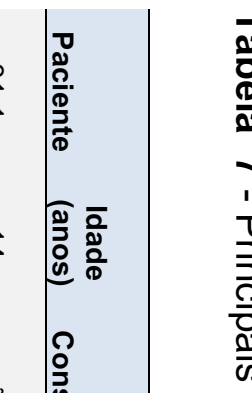

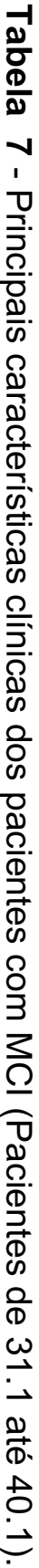

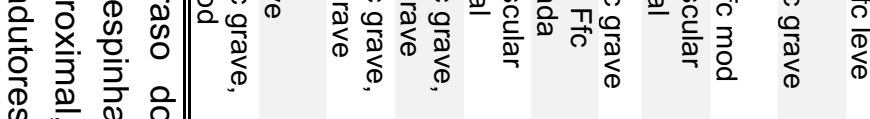


Tabela 8 - Exames complementares dos pacientes com MC

\begin{tabular}{|c|c|c|c|c|c|}
\hline Paciente & $\begin{array}{c}\text { Prova função } \\
\text { pulmonar }\end{array}$ & Ecocardiograma & ECG & CPK & ENMG \\
\hline 21.1 & não realizou & normal & normal & normal & normal \\
\hline 22.1 & Entre 60 e 80 & normal & normal & normal & miopática \\
\hline 23.1 & entre $40-60$ & normal & normal & normal & miopática \\
\hline 24.1 & aguardando & normal & normal & normal & miopática \\
\hline 25.1 & $C V F<40$ & normal & normal & normal & miopática \\
\hline 26.1 & $C V F<40$ & normal & normal & normal & miopática \\
\hline 27.1 & entre $40-60$ & normal & normal & normal & miopática \\
\hline 28.1 & não realizou & normal & normal & normal & normal \\
\hline 29.1 & não realizou & normal & normal & normal & normal \\
\hline 30.1 & CVF $<40$ & normal & normal & normal & miopática \\
\hline 31.1 & Entre 60 e 80 & normal & normal & normal & miopática \\
\hline 32.1 & Entre 60 e 80 & normal & normal & normal & miopática \\
\hline 33.1 & não realizou & normal & normal & normal & normal \\
\hline 34.1 & entre $40-60$ & normal & normal & normal & miopática \\
\hline 35.1 & Entre 60 e 80 & normal & normal & normal & miopática \\
\hline 36.1 & não realizou & normal & normal & normal & não realizou \\
\hline 36.2 & não realizou & normal & normal & normal & não realizou \\
\hline 37.1 & CVF $>80$ & normal & normal & normal & miopática \\
\hline 38.1 & Entre 60 e 80 & normal & normal & normal & neurogênica / miopática \\
\hline 39.1 & Entre 60 e 80 & normal & normal & normal & miopática \\
\hline 39.2 & não realizou & normal & normal & normal & não realizou \\
\hline 40.1 & entre $40-60$ & normal & normal & normal & miopática \\
\hline
\end{tabular}

CVF: capacidade viltal forçada, CPK: creatinofosfoquinase, Ecocardio: ecocardiograma, ENMG: eletroneuromiografia. 
Gráfico 6 - Principais características clínicas dos pacientes com $\mathrm{MCl}(\mathrm{N}=22)$.

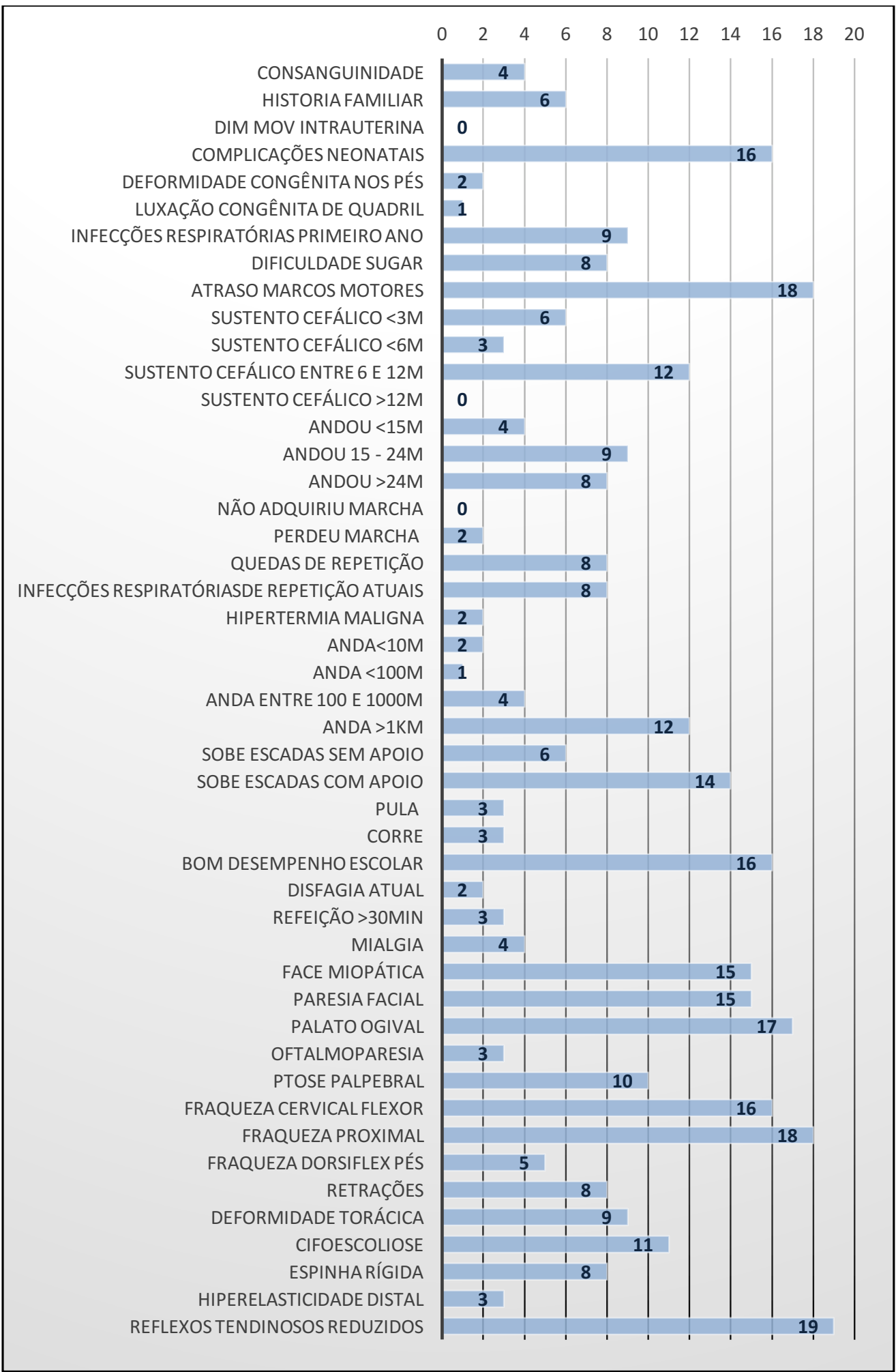


Gráfico 7 - Exames complementares dos pacientes com $\mathrm{MCl}(\mathrm{N}=22)$.

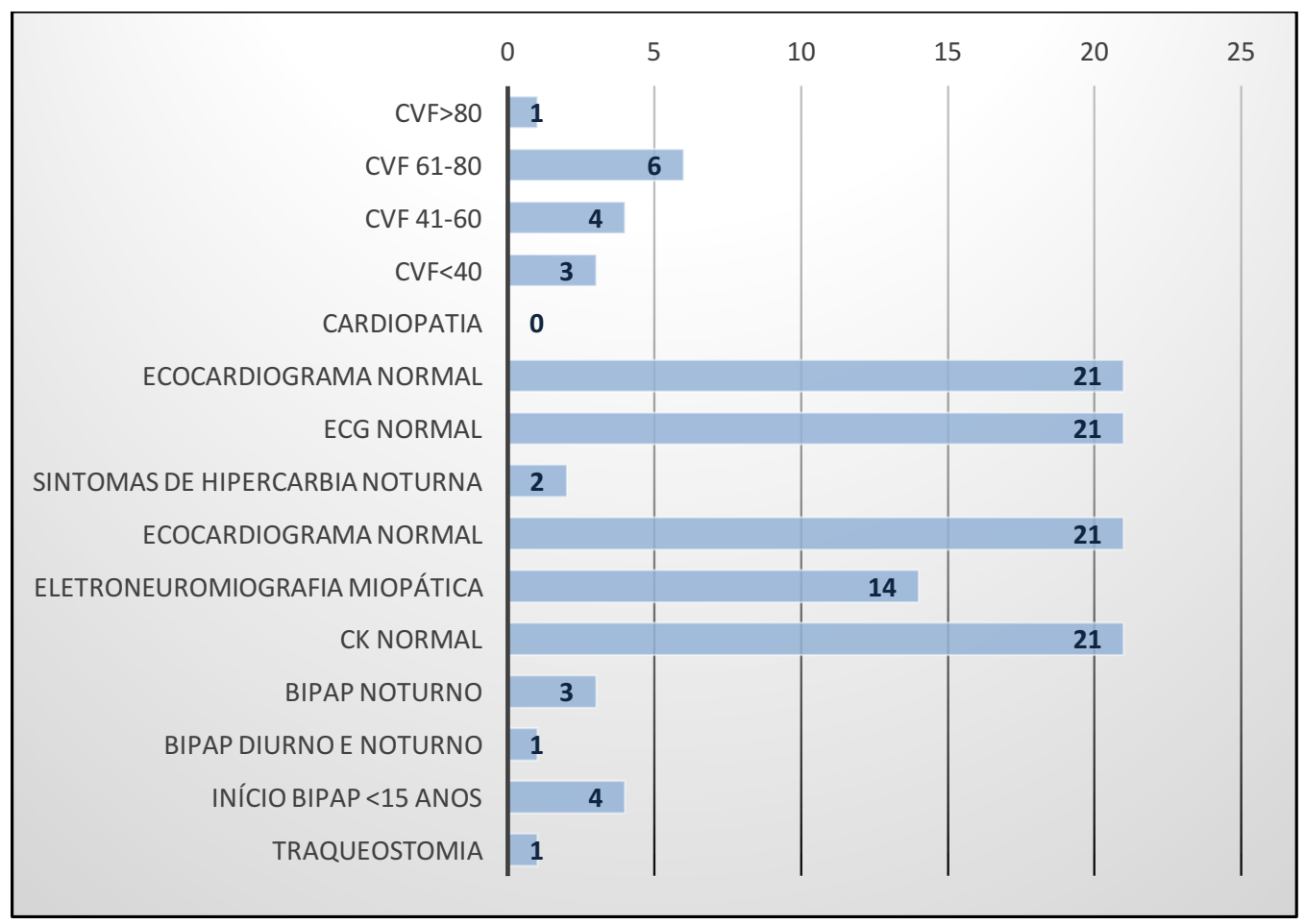


Gráfico 8 - Principais achados na biópsia muscular dos pacientes com MCl $(\mathrm{N}=22)$.

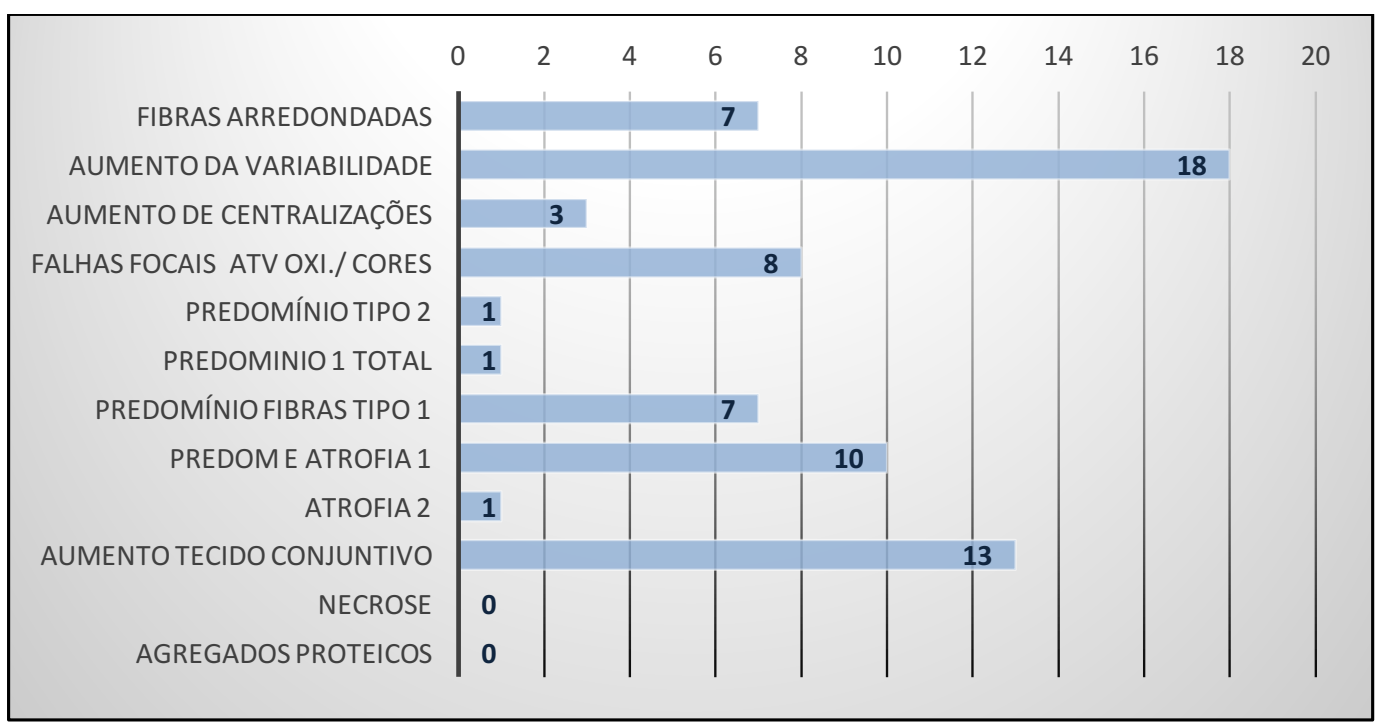

Gráfico 9 - Escolaridade e reabilitação dos pacientes com $\mathrm{MCl}(\mathrm{N}=22)$.

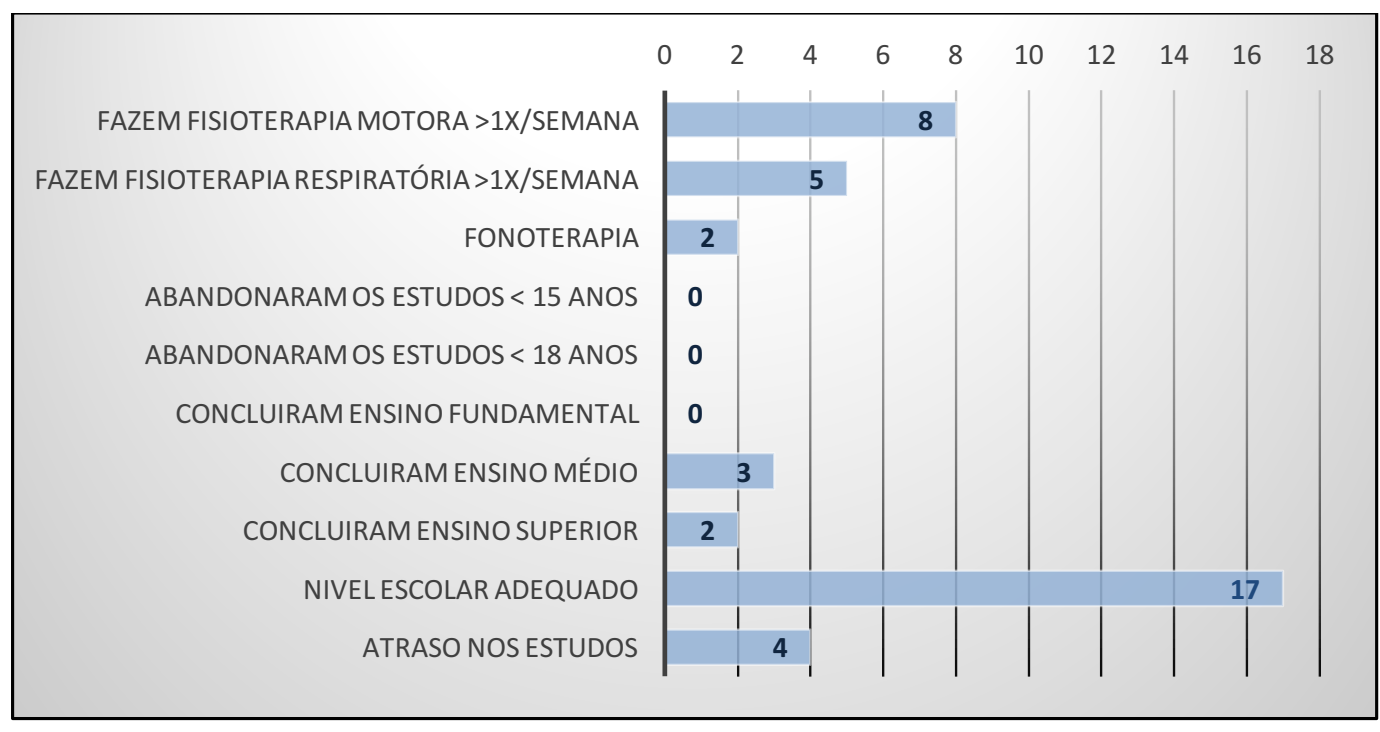



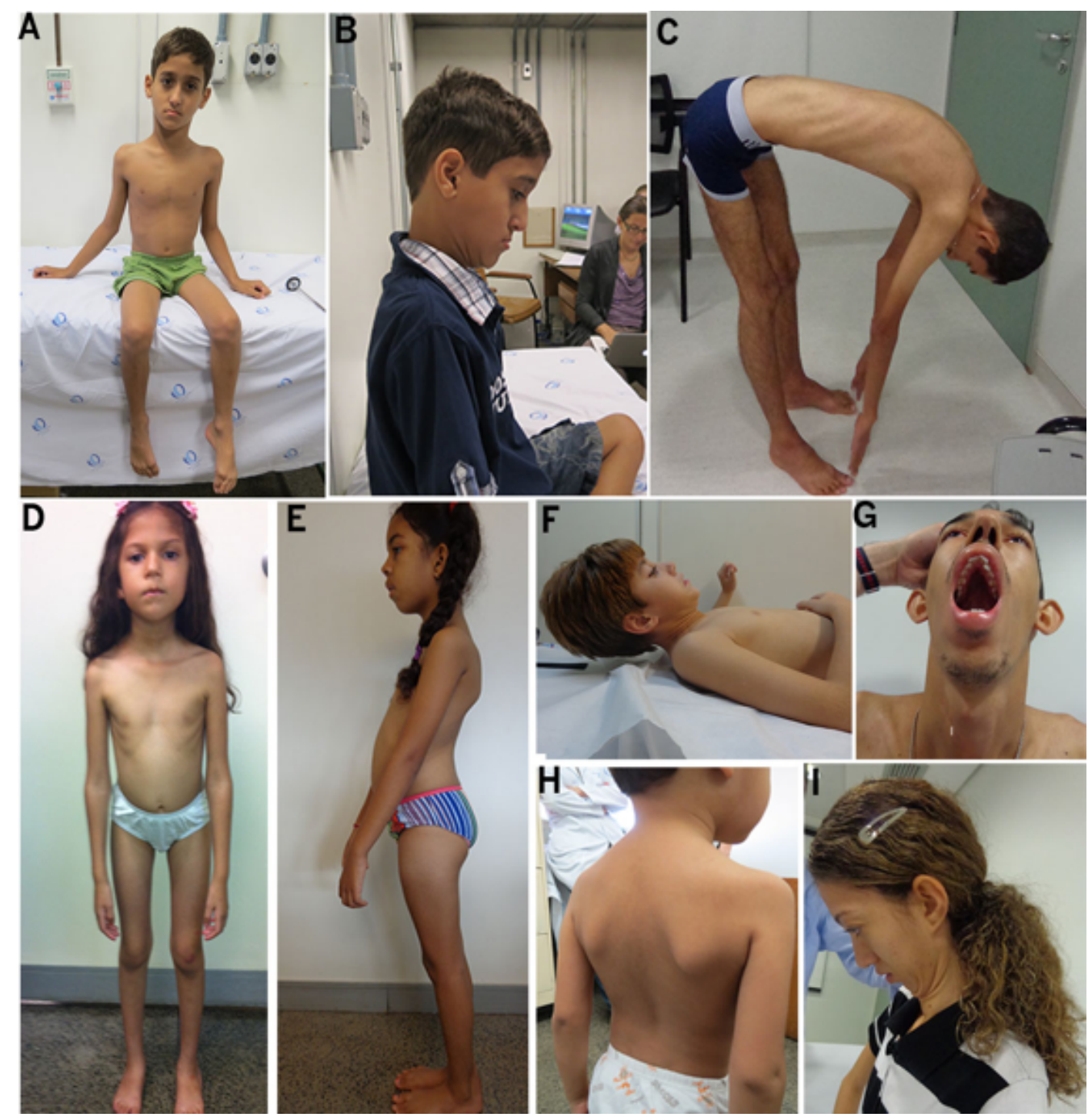

Figura 5 - Pacientes com $\mathrm{MCl}$ e espinha rígida. A: hipotrofia difusa (paciente 30.1 ). B: retração cervical (paciente 30.1). C: retração em musculatura paraespinhal com espinha rígida lombar (paciente 27.1). D: hipotrofia difusa e deformidade torácica (paciente 24.1). E: Hiperlordose (paciente 23.1). F: fraqueza flexores do pescoço (paciente 22.1). G: Palato ogival (paciente 27.1). H: escápula alada (paciente 29.1). I: retração cervica; (paciente 25.1). 

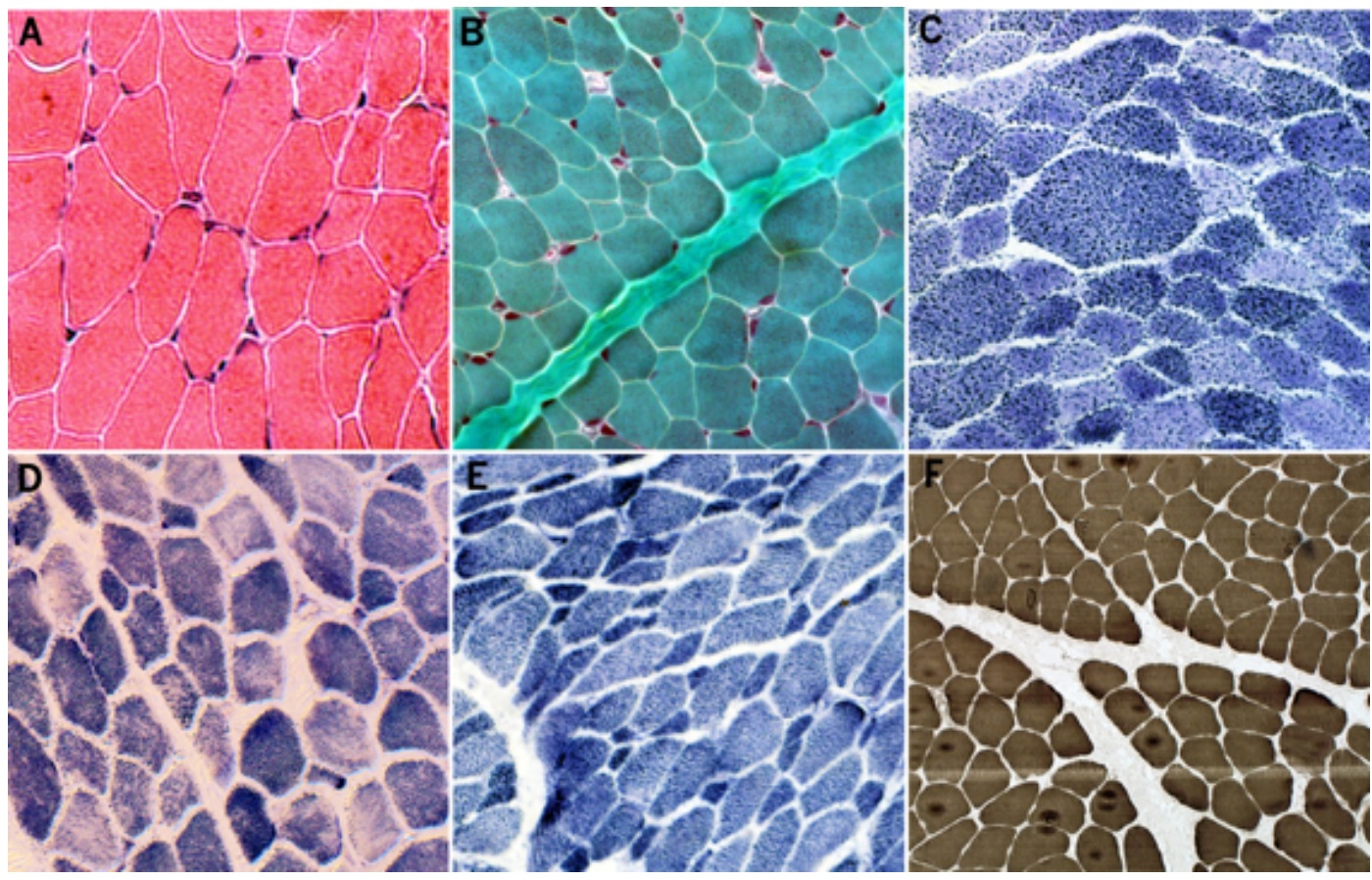

Figura 6 - Principais achados histológicos em biópsia muscular de pacientes com MCl. A. discreto aumento da variabilidade do tamanho das fibras (paciente 21.1) (HE, 40x). B: aumento do tecido conjuntivo (paciente 31.1) (GOM, 40x). C: arquitetura das fibras musculares preservada com aumento da variabilidade do tamanho das fibras $\mathrm{e}$ predomínio de fibras tipo 1 (paciente 34.1) (NADH, 40x). D: falhas focais da atividade oxidativa (paciente 37.1). E: atrofia e predomínio de fibras tipo 1 (paciente 23.1) (NADH, 40x). F: predomínio total de fibras tipo 2 (paciente 39.1) (ATPase 9,4, 20x). 


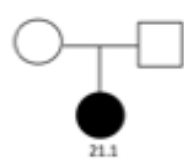

Familia 21

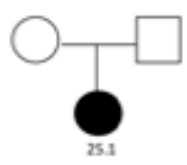

Familia 25

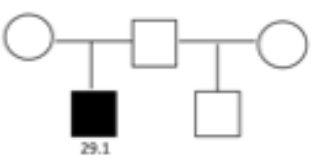

Familia 29

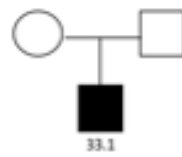

Familia 33

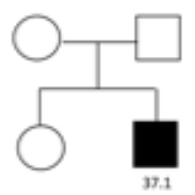

Familia 37

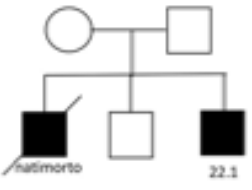

Familia 22

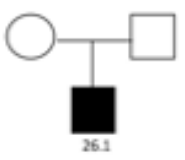

Familia 26

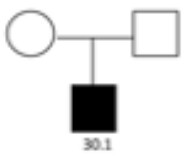

Familia 30

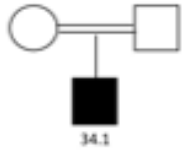

Familia 34

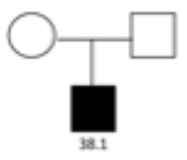

Familia 38

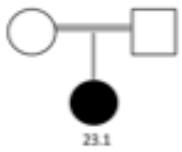

Familia 23

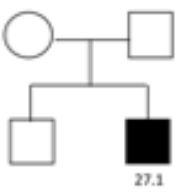

Familia 27

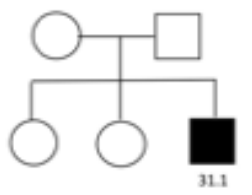

Familia 31
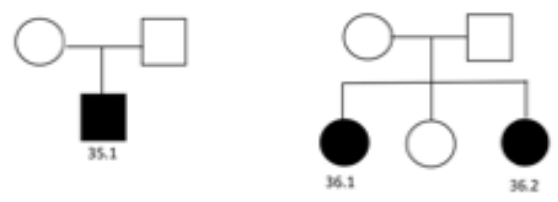

Familia 35

Familia 36

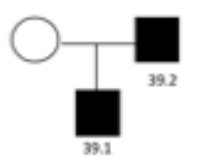

Familia 39

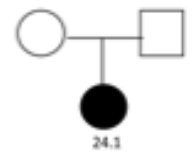

Familia 24

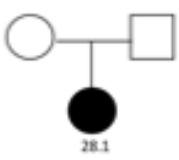

Familia 28

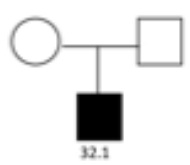

Familia 32

Figura 7 - Heredogramas das famílias da coorte de $\mathrm{MCl}$. 


\subsection{Resultados do estudo genético}

Encontramos neste estudo variantes patogênicas nos genes ACTA1 em 4 famílias com MN, NEB em 3 famílias com MN, RYR1 em 2 famílias com MCl, TPM3 em 2 famílias com MCI, TTN em uma família com $\mathrm{MCl}$ e $M Y H 7$ em 3 famílias com $\mathrm{MCl}$. Em 2 famílias com $\mathrm{MN}$ e em 5 famílias com $\mathrm{MCl}$ não foi estabelecido gene candidato mesmo após a análise do sequenciamento exômico. Não foram encontradas variantes patogênicas no gene TPM3 nos pacientes com MN nem no gene ACTA1 nos pacientes com $\mathrm{MCl}$. Os resultados do estudo genético constam na tabela 9. 
Tabela 9 - Resultados do estudo genético dos pacientes com MN e MCl.

\begin{tabular}{|c|c|c|c|c|c|}
\hline Paciente & Diagnóstico & Estudo Genético & Gene & Exon & Variante \\
\hline 1.1 & $\mathrm{MN}$ & analise exoma & $N E B$ & 134 & p.Thr7832fs \\
\hline 3.1 & $\mathrm{MN}$ & análise exoma & & & inconclusivo \\
\hline 6.1 & $\mathrm{MN}$ & Sanger & ACTA1 & 4 & p.Thr204lle \\
\hline 8.1 & $\mathrm{MN}$ & analise exoma & $N E B$ & $\begin{array}{l}\text { intron } 43 \\
\text { e exon } 63\end{array}$ & $\begin{array}{l}\text { c. } 5343+5 G>A / / \\
\text { c. } 8889+1 G>A,\end{array}$ \\
\hline 9.1 & $\mathrm{MN}$ & análise exoma & $N E B$ & 61 e 63 & $\begin{array}{c}\text { p.Ala2724Pro // } \\
\text { p.lle2919Val }\end{array}$ \\
\hline 10.1 & $\mathrm{MN}$ & analise exoma & & & inconclusivo \\
\hline 12.1 & $\mathrm{MN}$ & análise exoma & ACTA1 & 6 & p. Ser350Leu \\
\hline 13.1 & $\mathrm{MN}$ & Sanger & ACTA1 & 4 & p.His163Asp \\
\hline 17.1 & $\mathrm{MN}$ & Sanger & ACTA1 & 4 & p.Asp181His \\
\hline 21.1 & $\mathrm{MCl}$ & analise exoma & CHRNE & 2 & 136dupC \\
\hline 23.1 & $\mathrm{MCl}$ & análise exoma & TPM3 & 4 & p.Arg142Cys \\
\hline 24.1 & $\mathrm{MCl}$ & analise exoma & & & inconclusivo \\
\hline 25.1 & $\mathrm{MCl}$ & análise exoma & TPM3 & 5 & p.Arg168His \\
\hline 26.1 & $\mathrm{MCl}$ & análise exoma & & & inconclusivo \\
\hline 27.1 & $\mathrm{MCl}$ & análise exoma & RYR1 & 25 e 26 & $\begin{array}{l}\text { p.Arg1075GIn // } \\
\text { p.Glu1175Lys }\end{array}$ \\
\hline 28.1 & $\mathrm{MCl}$ & análise painel & $R Y R 1$ & & $\begin{array}{l}\text { p.Pro1586Leu // } \\
\text { p.Glu4635Lys }\end{array}$ \\
\hline 30.1 & $\mathrm{MCl}$ & análise painel & & & inconclusivo \\
\hline 31.1 & $\mathrm{MCl}$ & análise exoma & TTN & 194 e 166 & $\begin{array}{l}\text { p.Pro12803fs // } \\
\text { p.Glu12034* }\end{array}$ \\
\hline 33.1 & $\mathrm{MCl}$ & análise exoma & & & inconclusivo \\
\hline 34.1 & $\mathrm{MCl}$ & análise exoma & & & inconclusivo \\
\hline 38.1 & $\mathrm{MCl}$ & análise exoma & MYH7 & 34 & p.Arg1608Pro \\
\hline 39.1 & $\mathrm{MCl}$ & Sanger & MYH7 & 34 & p.Arg1608Pro \\
\hline 39.2 & $\mathrm{MCl}$ & Sanger & MYH7 & 34 & p.Leu1601Pro \\
\hline 40.1 & $\mathrm{MCl}$ & análise painel & MYH7 & 34 & $\begin{array}{c}\text { p.Arg1608Ser // } \\
\text { p.Ala1611Asp }\end{array}$ \\
\hline
\end{tabular}




\subsubsection{Pacientes com mutações no gene ACTA1}

Foi realizado o estudo do gene ACTA1 em todas as famílias com $\mathrm{MN}$ e em 6 famílias com $\mathrm{MCl}$. Foram encontradas mutações em heterozigose em quatro pacientes com $\mathrm{MN}(6.1,12.1,13.1$ e 17.1) - Figuras 8-11. As quatro variantes encontradas (tabela 9) já foram previamente descritas e associadas a MN.

A forma clínica de MN apresentada pelos pacientes com mutações no gene ACTA1, foi a congênita típica. As principais manifestações clínicas foram: hipotonia neonatal, dificuldade de sugar, dificuldade em ganhar peso, atraso dos marcos motores, deformidades esqueléticas, infecções respiratórias de repetição, fraqueza muscular com envolvimento da musculatura flexora do pescoço, flexora do tronco e proximal dos membros inferiores. Fraqueza distal foi encontrada apenas no paciente 6.1 .

O paciente 6.1 é do sexo masculino e foi avaliado aos 13 anos. Apresentou hipotonia neonatal e atraso dos marcos motores com sustento cefálico após os 12 meses e marcha após os 24 . Conseguia deambular mais que $1 \mathrm{~km}$ no plano e subir escadas sem apoio. Negou queixas como mialgia, fadiga e câimbras. Ao exame clínico apresentou fraqueza leve de predomínio proximal com envolvimento grave dos flexores cervicais e moderado dos dorsiflexores dos pés Os valores de CPK eram normais, bem como, ecocardiograma e eletrocardiograma. A eletroneuromiografia realizada precocemente na investigação tinha padrão miopático e apresentou distúrbio ventilatório leve (CVF maior que 60\%) na prova de função respiratória. A biópsia 
muscular, realizada aos 3 anos apresentou escassos bastões subsarcolemais e intracitoplasmáticos com importante DCTF (figura 8).

O paciente 12.1 (figura 9) é do sexo masculino, filho único de pais não consanguíneos, sem história familiar de miopatia ou outra doença neuromuscular. Foi avaliado aos 14 anos. Iniciou investigação devido a hipotonia neonatal e atraso na aquisição dos marcos motores. Adquiriu sustento cefálico aos 5 meses e marcha aos 18, apresentava disfagia com dificuldade em ganhar peso e apresentou infecções respiratórias frequentes nos primeiros 2 anos de vida sem necessidade de suporte ventilatório durante os eventos infecciosos. Evoluiu inicialmente com ganhos motores, melhora na parte respiratória e da deglutição, mas aos 9 anos apresentou piora da fraqueza proximal e aparecimento de deformidades osteoesqueléticas como cifoescoliose, retrações tendíneas em pescoço, punho, cotovelos e joelhos, e piora do padrão respiratório com diminuição da capacidade vital forçada. Realizou correção cirúrgica da escoliose aos 10 anos com melhora e estabilização do padrão respiratório. Perdeu a marcha aos 12 anos. Ao exame clínico apresentou fraqueza grave de predomínio proximal com envolvimento dos flexores cervicais. Devido as retrações tendinosas em cotovelos, punhos, joelhos e pés o exame de força de porções distais ficou comprometido. Seus exames complementares mostraram valores normais de CPK, ENMG realizada aos dois anos de idade, com padrão miopático e espirometria com distúrbio ventilatório grave. Ecocardiograma, holter e eletrocardiograma estavam normais. Apesar do distúrbio ventilatório grave, o paciente fazia uso do aparelho de suporte ventilatório binível esporadicamente atribuindo a uma má adaptação ao aparelho. Abandonou os estudos aos 14 anos referindo dores musculares, apesar da adaptação da cadeira e não fazia 
regularmente fisioterapia respiratória ou motora. A biópsia muscular, realizada aos 6 anos, mostrou aumento moderado da variabilidade no tamanho das fibras, ausência de necrose, ausência de inflamação, aumento pronunciado de tecido conjuntivo, falhas focais da arquitetura interna (core-like) e presença de agregados proteicos, massas citoplasmáticas, e bastões nemalínicos distribuídos difusamente pelo citoplasma em menos de $50 \%$ das fibras.

O paciente 13.1 (figura 10) é do sexo masculino, filho único de pais não consanguíneos, sem história familiar de miopatia, iniciou investigação por hipotonia neonatal e atraso da aquisição dos marcos motores. Apresentou disfagia grave no período neonatal e necessitou de sonda para alimentação nos primeiros dois meses. Infecções respiratórias repetidas nos primeiros dois anos de vida o levaram a vários episódios de internação hospitalar, mas sem necessidade de suporte ventilatório nestes eventos. O sustento cefálico foi obtido após o primeiro ano de vida e marcha após os três anos. Evoluiu com ganhos motores e melhora parcial da disfagia, no entanto, desde os 10 anos notou uma piora lentamente progressiva da fraqueza muscular e o aparecimento de deformidade osteoesqueléticas (cifoescoliose e deformidade torácica). $\mathrm{Na}$ última avaliação queixou-se de cansaço aos esforços, não conseguia subir degraus e necessitava de apoio para se levantar da posição sentada. No plano conseguia deambular até 10 metros sem precisar descansar. Ao exame clínico apresentou fraqueza leve a moderada de predomínio proximal com envolvimento grave dos flexores cervicais e dos dorsiflexores dos pés. Apresentou também deformidade torácica, cifoescoliose leve e espinha rígida. Exames complementares mostraram valores normais de CPK, ENMG com padrão miopático, ecocardiograma normal, eletrocardiograma normal e espirometria 
com distúrbio ventilatório restritivo grave (CVF<40\%). A biópsia muscular foi realizada aos 10 anos e evidenciou aumento pronunciado da variabilidade no tamanho das fibras, predomínio e atrofia de fibras tipo 1, ausência de necrose, ausência de inflamação, aumento do glicogênio em fibras tipo 2, aumento pronunciado de tecido conjuntivo com presença de agregados proteicos, bastões subsarcolemais e intranucleares.

O paciente 17.1 é do sexo masculino e foi avaliado aos 46 anos. Apresentou hipotonia neonatal e atraos dos marcos motores com sustento cefálico aos 9 meses e marcha após os 5 anos. Na avaliação ele era cadeirante há 18 anos, perdeu a marcha aos 28 anos, mas conseguia ficar em pé, trocar passos e realizar trocas posturais. O paciente tocava manualmente a sua própria cadeira, não usava cadeira motorizada e apresentava um bom desempenho funcional. Ao exame clínico apresentou fraqueza de predomínio proximal com envolvimento moderado dos flexores cervicais e dos dorsiflexores dos pés. Apresentou exames cardiológicos normais e espirometria evidenciando distúrbio ventilatório moderado. Realizou três biópsias musculares, uma aos 14 anos, uma aos 15 e a última aos 28 anos. Todas apresentaram discreto aumento da variabilidade do tamanho das fibras com preservação da sua arquitetura interna e presença de bastões subsarcolemais em 100\% das fibras (figura 11). 

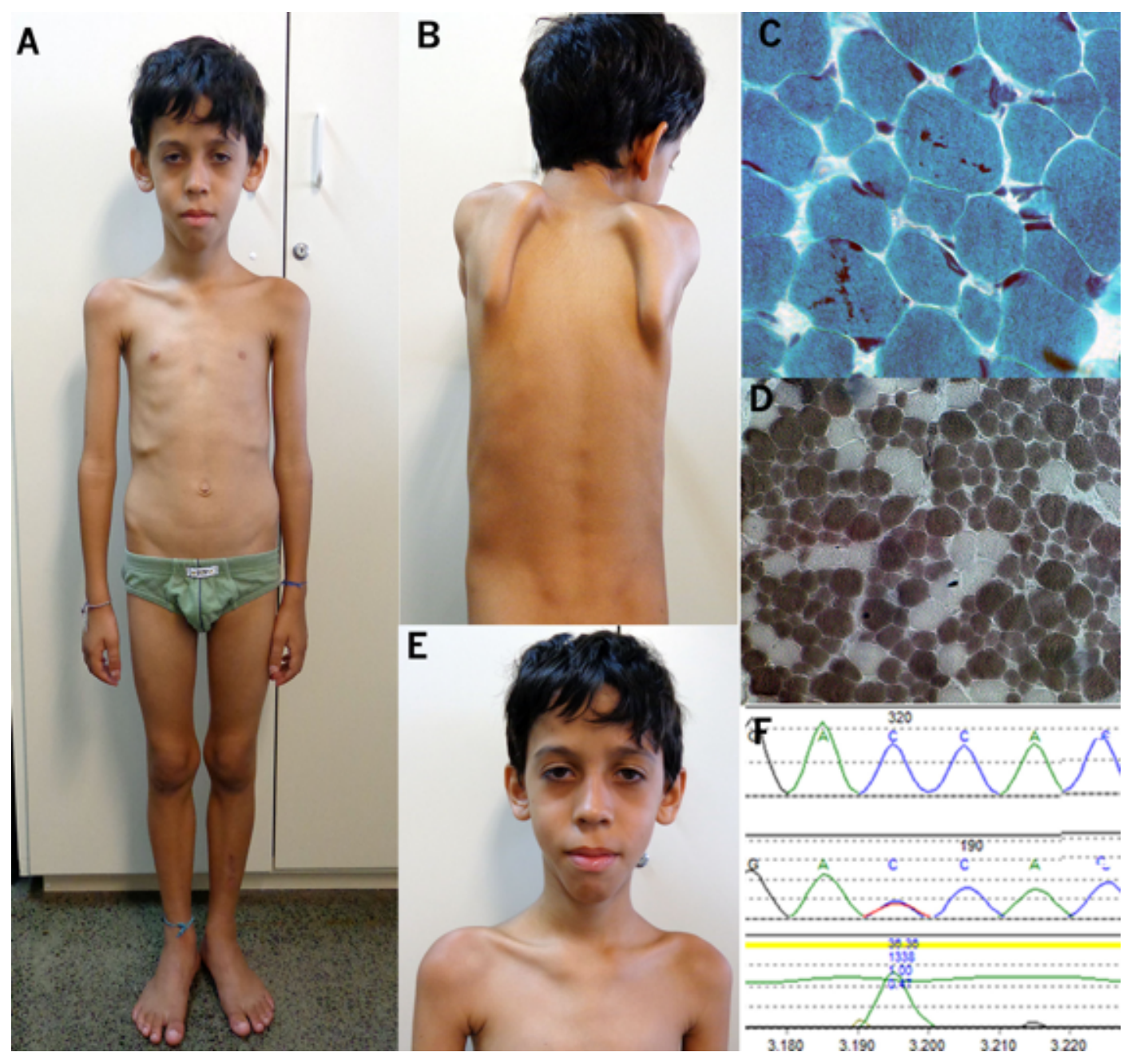

Figura 8 - Paciente 6.1 (MN). A e E: hipotrofia difusa e face miopática. B: escápula alada. C: biópsia muscular mostrando bastões nemalínicos esparsos e intracitoplasmáticos $(\mathrm{GO}, 40 \mathrm{x})$. D: biópsia muscular mostrando predomínio e atrofia de fibras tipo 1 (ATPase 4.3). F: Mutação p.Thr204lle no gene ACTA1. 

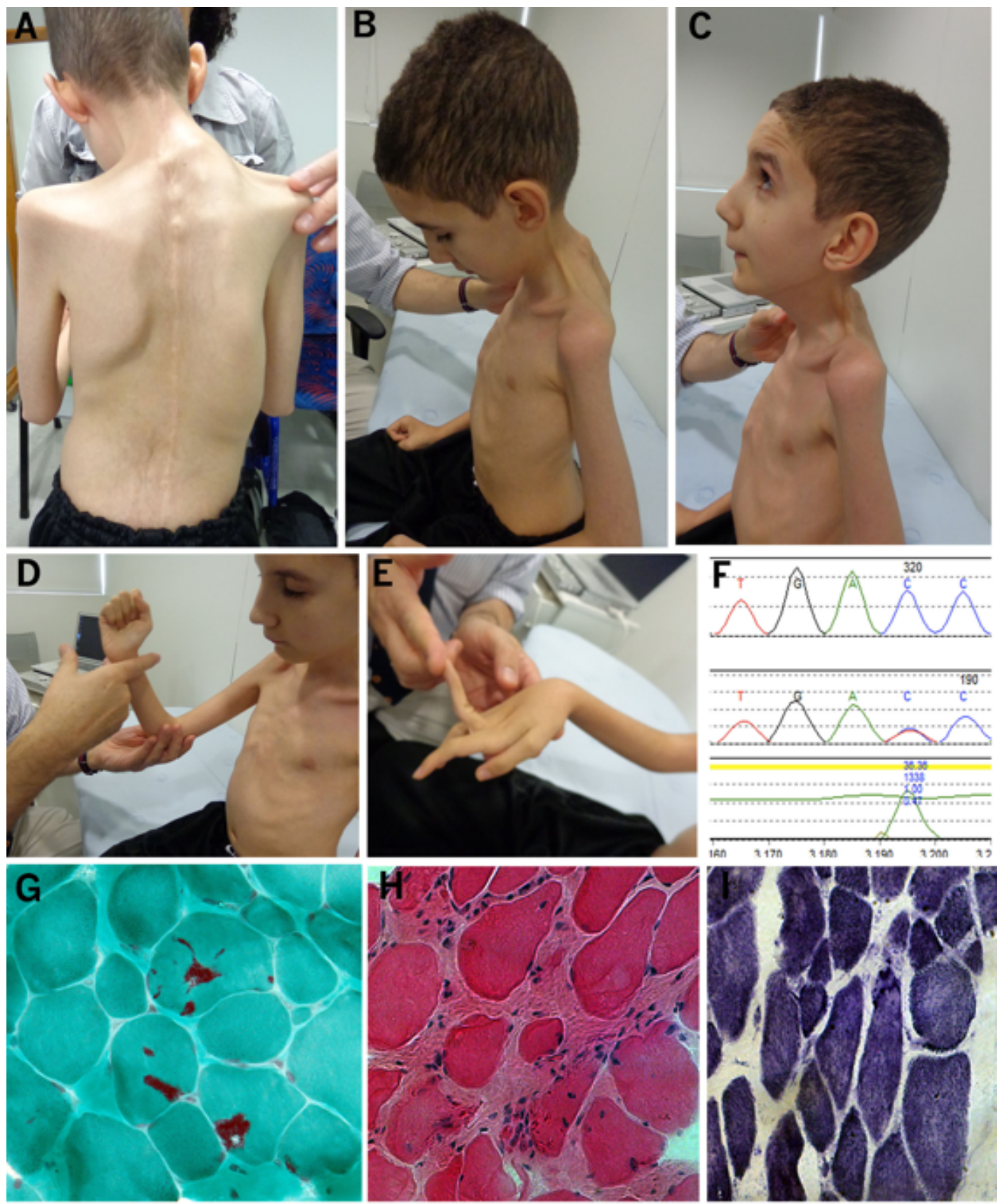

Figura 9 - Paciente 12.1 (MN). A: deformidade torácica e cifoescoliose. B e C: retração cervical. D: retração em cotovelos. E: hiperelasticidade distal. F: Mutação c.1050 C>CT (p. Ser350Leu) no gene ACTA1. G: biópsia muscular evidenciando agregados proteicos em forma filamentosa e de bastões $(\mathrm{GO}, 40 \mathrm{x})$. $\mathrm{H}$ : biópsia muscular mostrando aumento do tecido conjuntivo e aumento da variabilidade no tamanho das fibras (HE, 40x). I: biópsia muscular mostrando falhas focais de atividade oxidativa (NADH-TR, 40x). 


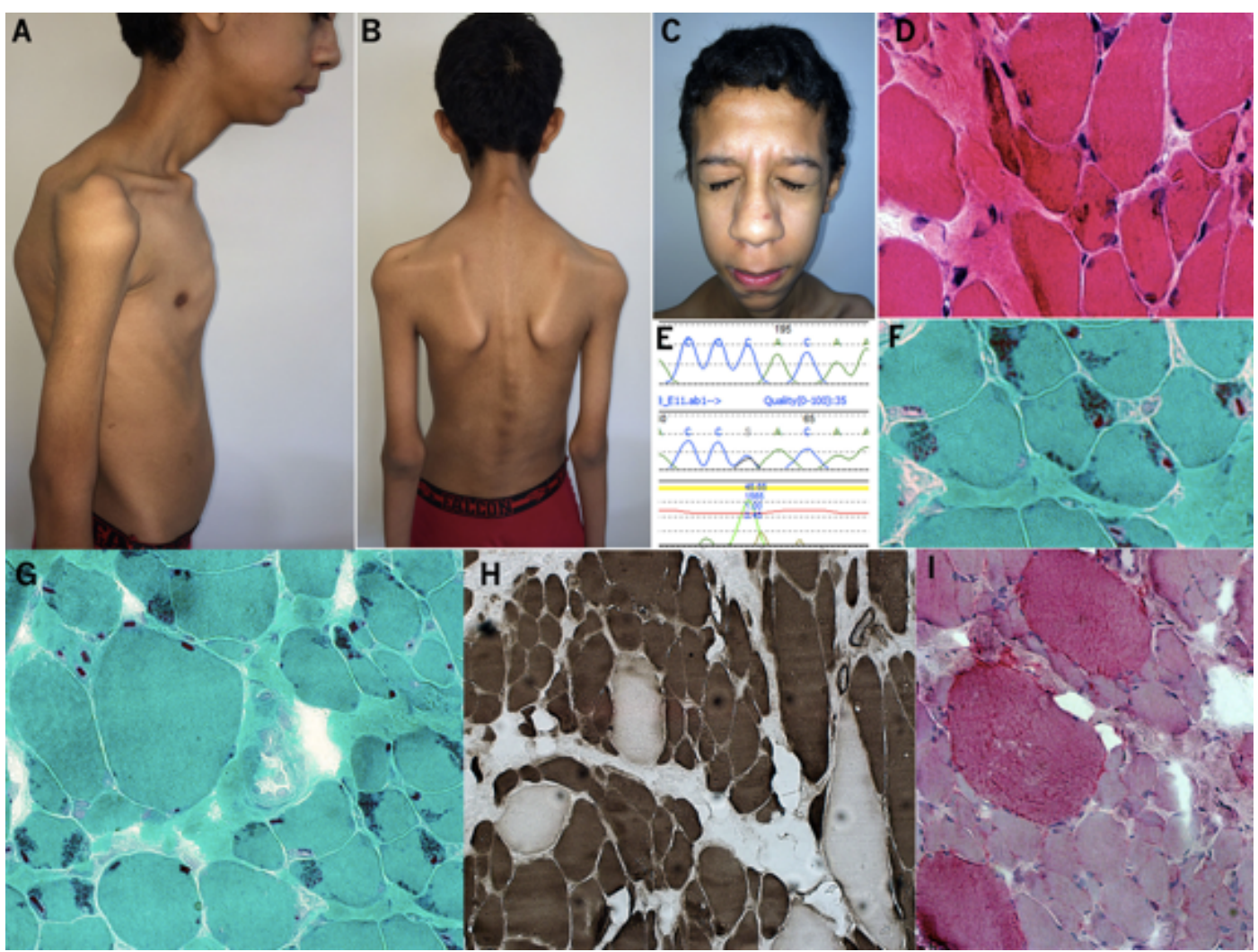

Figura 10 - Paciente 13.1 (MN). A) deformidade torácica. B) cifoescoliose e escapula alada. C) face miopática com paresia facial. D) Biópsia muscular com a presença de agregados proteicos intracitoplasmáticos e aumento da variabilidade do tamanho das fibras (HE, 40x). E) mutação p.His163Asp no gene ACTA1. Biópsia muscular mostrando bastões nemalínicos subsarcolemais e intranucleares na maioria das fibras (GO, 40x) ( $F$ e G); predomínio e atrofia de fibras tipo 1 e hipertrofia de fibras tipo 2 (ATPase 4.3, $40 \mathrm{x})(\mathrm{H})$ e hipertrofia de fibras tipo 2 com aumento de glicogênio (PAS, 40x) (I). 

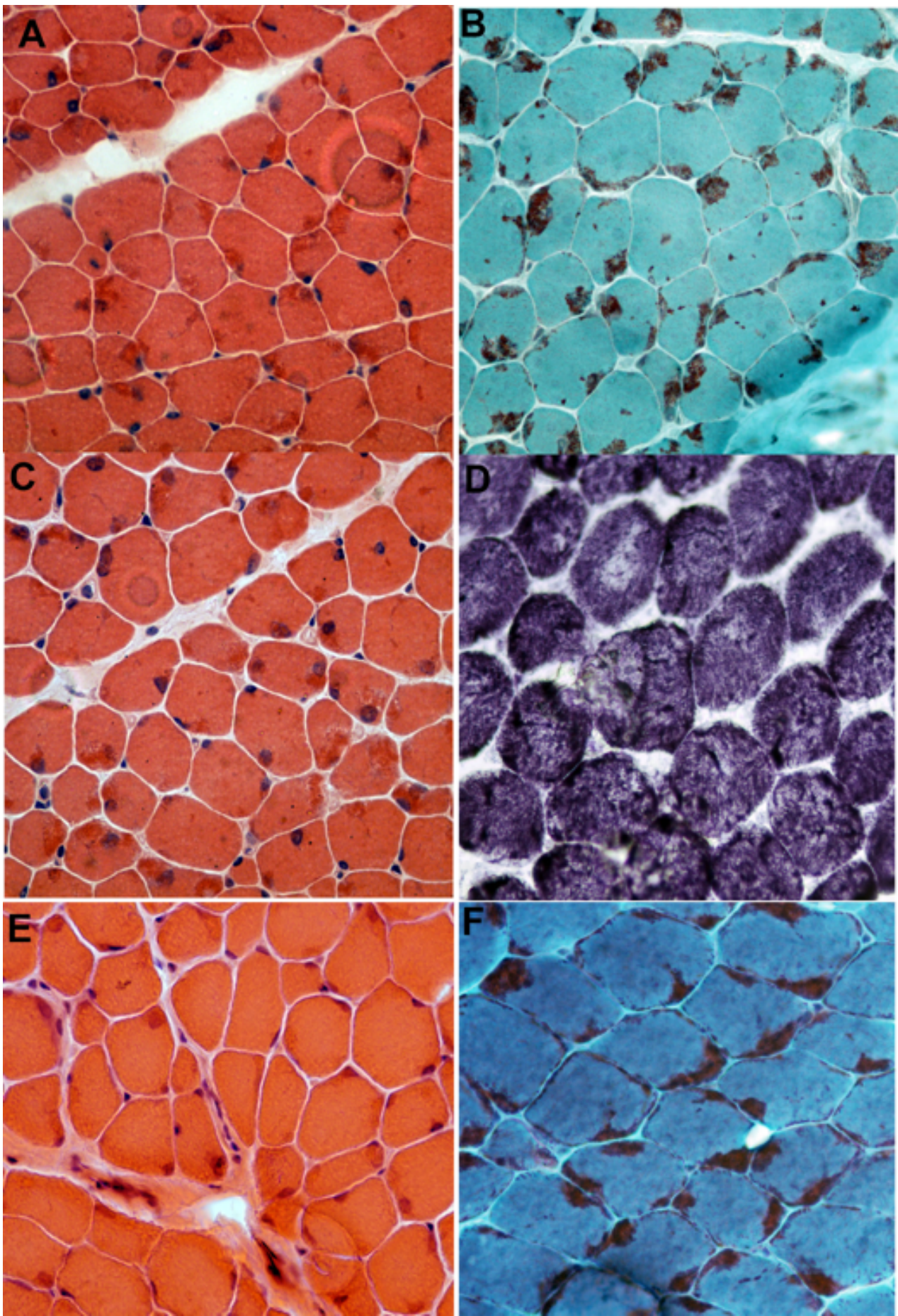

Figura 11 - Biópsias musculares do paciente 17.1 (MN): Biópsias realizadas aos 14 anos (A e B), 15 anos (C e D) e 29 anos (E e F). Observar a presença dos bastões nemalínicos de localização subsarcolemal na coloração GO, 40x (B e F), a discreta variabilidade do tamanho das fibras com discreto aumento de tecido conjuntivo (HE, $40 x)(A, C$ e E) e a presença de falhas de atividade oxidativa na região dos bastões (NADH 40x) (D). Observar que não houve piora no padrão histológico. 


\subsubsection{Pacientes com variante patogênica no gene NEB}

Variantes patogênicas no gene NEB foram encontradas em 3 famílias através de sequenciamento exômico (figura 12). Foram detectadas duas variantes em heterozigose com alta predição de patogenicidade no SE nos pacientes 8.1 e 9.1 e apenas 1 variante em heterozigose na paciente 1.1 .

A família 1 é uma família não consanguínea, com prole de quatro, sendo duas filhas afetadas. As pacientes 1.1 e 1.2, ambas do sexo feminino, apresentaram quadro de hipotonia neonatal e sucção débil, mas apenas a paciente 1.1 apresentou atraso importante dos marcos motores. Ela foi avaliada aos 19 anos, apresentou atraso dos marcos motores com sustento cefálico aos 5 meses e marcha aos 15 meses, sem atraso de linguagem. Evoluiu com ganhos motores mas apresentou piora da fraqueza proximal e deformidades em tórax e na coluna. Neste mesmo período iniciou uso de suporte ventilatório mantido na data da avaliação. Na avaliação referiu quadro motor estável, conseguia deambular entre 100 e 1000m no plano e subir escadas sem apoio. Negou queixas como mialgia, fadiga e câimbras. Ao exame clínico apresentou fraqueza moderada de predomínio proximal com envolvimento grave dos flexores cervicais e dos dorsiflexores dos pés. Apresentava também envolvimento facial proeminente, deformidade torácica e cifoescoliose leve. Os valores de CPK eram normais, bem como, ecocardiograma e eletrocardiograma. Apresentou distúrbio ventilatório grave na prova de função respiratória e fazia uso de suporte ventilatório binível desde os 13 anos. 
Já a paciente 1.2, avaliada aos 21 anos, foi a primeira filha do casal. Negou atraso motor, mas procurou o atendimento médico por hipotonia, dificuldade de sugar, engasgos frequentes, e em seguida quedas de repetição e dificuldade de subir degraus. O diagnóstico foi realizado apenas após o nascimento da irmã com sintomas semelhantes aos 3 anos de idade. A paciente apresentou quadro motor estável até apresentar infecção respiratória grave aos 15 anos, necessitou de internação com cuidados intensivos, foi intubada e permaneceu na UTI por mais de 30 dias. Nesta ocasião a paciente se alimentava por sonda e foi realizada traqueostomia. A paciente teve piora da fraqueza, não conseguia se levantar, andar, nem sentar sem apoio. Os ganhos motores foram sendo restabelecidos em cerca de um ano após a alta hospitalar com o apoio fisioterápico. Na data da avaliação, a paciente deambulava no plano mais que $1000 \mathrm{~m}$ e conseguia se levantar apenas com apoio unilateral. O exame clínico foi semelhante ao da irmã. Os valores de CPK eram normais, bem como, ecocardiograma e eletrocardiograma. Apresentou distúrbio ventilatório grave na prova de função respiratória e fazia uso de suporte ventilatório binível desde os 15 anos. Ambas as pacientes foram submetidas a biópsia muscular com um e três anos de vida respectivamente nas quais foram visualizados bastões nemalínicos subsarcolemais, leve aumento da variabilidade do tamanho das fibras com preservação da sua arquitetura interna, ausência de necrose e moderado aumento do tecido conjuntivo. Foi encontrada apenas uma mutação em frameshift através do sequenciamento exômico, no entanto após verificar a cobertura para este gene, foi observado que 10 exons não foram adequadamente cobertos. E o seu estudo deverá ser complementado. 
O paciente 8.1 é do sexo masculino, filho único de pais não consanguíneos, sem história familiar para miopatia ou outras doenças neuromusculares. O paciente apresentou hipotonia neonatal e atraso dos marcos motores com sustento cefálico aos 12 e marcha aos 18 meses. Apresentou dificuldade de sugar, engasgos frequentes e infecções respiratórias de repetição nos primeiros anos de vida com melhora gradual destas queixas ainda na primeira década. Foi avaliado aos 12 anos e referia andar no plano por mais de $1000 \mathrm{~m}$, subia degraus sem apoio e corria por pequenas distâncias. . Ao exame clínico apresentou fraqueza leve de predomínio proximal com envolvimento moderado dos flexores cervicais. Os exames complementares mostraram valores normais de CPK, ENMG com padrão miopático, espirometria com distúrbio ventilatório leve, ecocardiograma, holter e eletrocardiograma, normais. O paciente não fazia uso de aparelho de suporte ventilatório ou órteses. Apresenta bom desempenho escolar e já havia concluído o ensino fundamental. A biópsia muscular mostrou aumento discreto da variabilidade no tamanho das fibras, ausência de necrose, ausência de inflamação, falhas focais da arquitetura interna e presença bastões nemalínicos subsarcolemais em cerca de $50 \%$ das fibras.

O paciente 9.1 é do sexo masculino, quarto filho de uma prole de quatro de pais não consanguíneos, sem história familiar para miopatia ou outras doenças neuromusculares. O paciente apresentou hipotonia neonatal grave, não conseguia sugar evoluiu com pneumonia aspirativa logo ao nascer, ficou internado com necessidade de suporte ventilatório e apresentou sangramento intracerebral. O paciente se recuperou lentamente tendo alta da unidade intensiva após 20 dias. Apresentou atraso dos marcos motores com sustento 
cefálico aos 6 meses e marcha aos 30 meses. Se manteve com disfagia importante, infecções respiratórias repetidas e dificuldade de ganho de peso, sendo realizada gastrostomia, sendo esta, a via de alimentação preferida até a data de avaliação. Foi avaliado aos 13 anos e referia andar no plano por menos de 100m, não conseguia correr, pular ou subir degraus. Ao exame clínico apresentou fraqueza moderada de predomínio proximal com envolvimento grave dos flexores cervicais e leve dos dorsiflexores dos pés. Os exames complementares mostraram valores normais de CPK, ENMG com padrão miopático e espirometria com distúrbio ventilatório grave. Ecocardiograma, holter e eletrocardiograma estavam normais. O paciente iniciou o uso de aparelho de suporte ventilatório binível aos oito anos e o utilizava durante todo o sono (diurno ou noturno), durante o dia quando se sentia mais cansado e quando voltava da escola por algumas horas. Apresentava bom desempenho escolar, no entanto, teve atraso escolar por causa das sucessivas internações. A biópsia muscular mostrou aumento discreto da variabilidade no tamanho das fibras, ausência de necrose, ausência de inflamação, falhas focais da arquitetura interna e presença bastões nemalínicos aglomerados na região subsarcolemal em 100\% das fibras, formando massas citoplasmáticas em algumas fibras. 


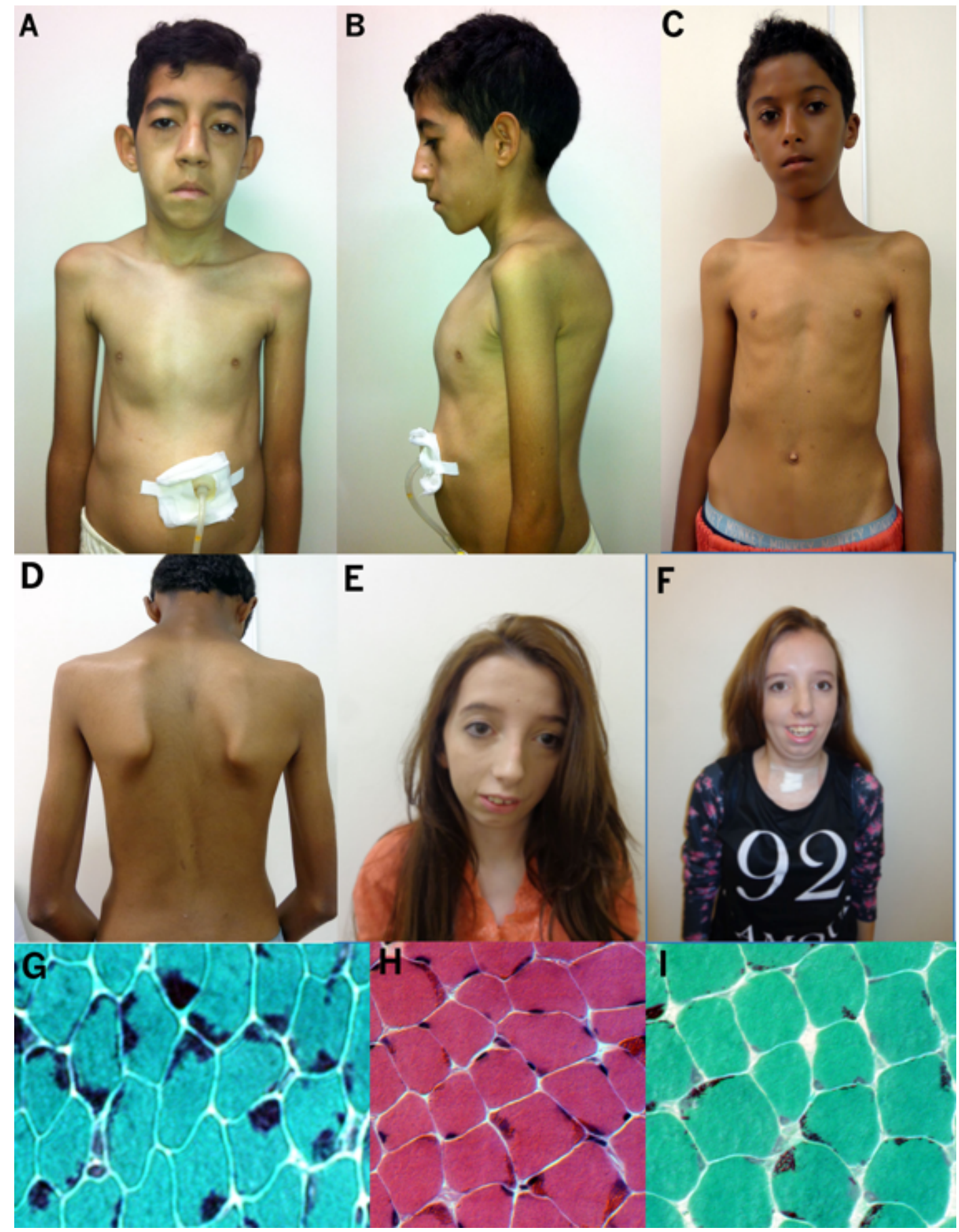

Figura 12 - Pacientes com variantes patogênicas no gene NEB. A e B) Observar importante envolvimento facial, hipotrofia difusa e deformidade torácica no paciente 9.1. C e D) Observar hipotrofia difusa, envolvimento facial leve, cifoescoliose leve e escápula alada no paciente 8.1. E e F) Importante envolvimento facial nos pacientes 1.1 e 1.2, respectivamente. G) Biópsia muscular do paciente 9.1 mostrando bastões nemalínicos subsarcolemais em $100 \%$ das fibras e massas citoplasmáticas (GO, 40x). Biópsia muscular do paciente 8.1 mostrando bastões nemalínicos subsarcolemais em $50 \%$ das fibras (HE 40x) (H) e (GO, 40x) (I). 


\subsubsection{Pacientes com variante patogênica no gene CHRNE}

Foi detectada a variante patogênica $136 \mathrm{dupC}$ no exon 2 do gene CHRNE na paciente 21.1 (figura 13) através do sequenciamento exômico. Esta variante já foi previamente relatada em pacientes com miastenia congênita.

A paciente 21.1 é do sexo feminino, filha única de pais não consanguíneos sem história familiar de miopatia ou de outras doenças neuromusculares. Logo ao nascer, foi detectada luxação congênita de quadril e deformidade dos pés sendo submetida a vários procedimentos cirúrgicos desde então. Era hipotônica, com importante envolvimento facial e dificuldade para sugar. Apresentou atraso dos marcos motores principalmente atribuídos a luxação congênita de quadril e dos pés com sustento cefálico aos dois meses e marcha após os três anos. Apresentou atraso de linguagem atribuído a disfonia com boa compreensão de comandos, sem evidência de comprometimento cognitivo. A paciente evoluiu com ganhos motores e melhora da linguagem. Os exames complementares mostraram valores normais de CPK, ENMG com padrão miopático, ecocardiograma, holter e eletrocardiograma normais. A paciente ainda realizou a espirometria. Biópsia muscular foi realizada com menos de um ano de vida e mostrou achados leves e inespecíficos com leve aumento na variabilidade no tamanho das fibras e predomínio e atrofia de fibras tipo 1. 


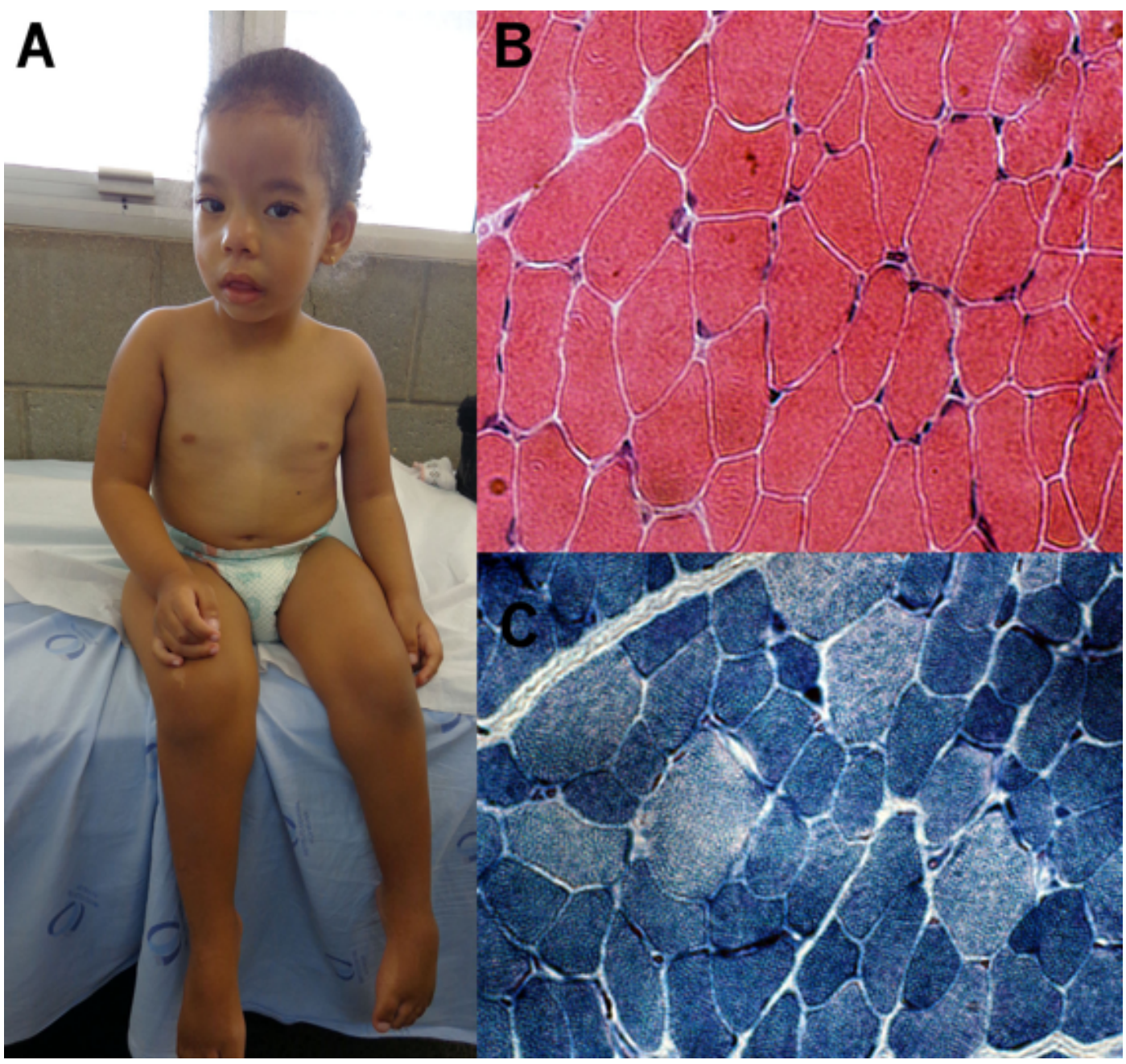

Figura 13 - Paciente com variante patogênica no gene CHRNE. A) Paciente 21.1 com deformidade nos pés, face alongada e paresia facial bilateral e simétrica. $B$ e C) Biópsia muscular do paciente $21.1 \mathrm{com}$ leve aumento na variabilidade no tamanho das fibras e predomínio e atrofia de fibras tipo 1 (HE 40x e NADH-TR 40x, respectivamente). 


\subsubsection{Pacientes com variante patogênica no gene TPM3}

Foram detectadas variantes patogênicas no gene TPM3 em duas pacientes com $\mathrm{MCl}$ e espinha rígida através do sequenciamento exômico. A paciente 23.1 apresentou uma variante nova em homozigose (p.Arg142Cys) e a paciente 25.1, uma variante missense em heterozigose (p.Arg168His), já previamente descritas em DCTF.

A paciente 23.1 é do sexo feminino, filha única de pais consanguíneos sem história familiar de miopatia ou outras doenças neuromusculares. Nasceu hipotônica, com dificuldade para sugar e ganhar peso, e infecções respiratórias recorrentes nos primeiros dois anos de vida. Apresentou atraso dos marcos motores com sustento cefálico aos nove meses e marcha após os dois anos de vida sem atraso de linguagem. A paciente evoluiu com ganhos motores e melhora da disfagia. Foi avaliada aos 10 anos e referiu deambular no plano mais que $1000 \mathrm{~m}$, necessitava de apoio unilateral para subir degraus, não conseguia pular ou correr e relatava um bom desempenho motor. Ao exame clínico apresentou fraqueza leve/moderada de predomínio proximal com envolvimento grave dos flexores cervicais, deformidade torácica leve e espinha rígida. Ao exame apresentava envolvimento facial com face miopática, paresia facial bilateral, ptose palpebral bilateral não flutuante e fraqueza de predomínio proximal nos membros superiores e inferiores. Não apresentava retrações tendíneas, mas apresentava limitação para a flexão do tronco, espinha rígida e cifoescoliose leve. Os exames complementares mostraram valores normais de CPK, ENMG com padrão miopático, espirometria com distúrbio ventilatório moderado, ecocardiograma, holter e eletrocardiograma normais. 
A paciente 25.1 é do sexo feminino, filha única de pais não consanguíneos sem história familiar de miopatia ou outras doenças neuromusculares. Não apresentou complicações neonatais, mas apresentava dificuldade para sugar e ganhar peso. Apresentou atraso dos marcos motores com sustento cefálico aos 10 meses e marcha após os dois anos de vida, sem atraso de linguagem. A paciente evoluiu com ganhos motores, quadro motor estável, no entanto, evoluiu durante adolescência com cifoescoliose grave de rápida evolução e distúrbio ventilatório restritivo grave. Neste período foi submetida a correção cirúrgica da coluna e iniciou uso de suporte ventilatório tipo binível. Foi avaliada aos 24 anos com quadro estável, sem infecções respiratórias recorrentes, deambulava mais que $1000 \mathrm{~m}$ no plano e necessitava de apoio unilateral para subir degraus e se levantar. Apresentou bom desempenho escolar e estava no ensino superior. Ao exame apresentava envolvimento facial com face miopática, hipotrofia difusa, e fraqueza leve de predomínio proximal nos membros superiores e inferiores, com importante envolvimento axial. Não apresentava retrações tendíneas, mas apresentava limitação para todos os movimentos do tronco e pescoço. Os exames complementares mostraram valores normais de CPK, ENMG com padrão miopático, espirometria com distúrbio ventilatório grave e exames cardiológicos normais.

Quanto aos aspectos histológicos, ambas as pacientes apresentaram importante desproporção de tipo de fibras com fibras do tipo 1 mais que $50 \%$ menores que as fibras tipo 2 sem falhas focais de arquitetura interna ou outras alterações estruturais. 


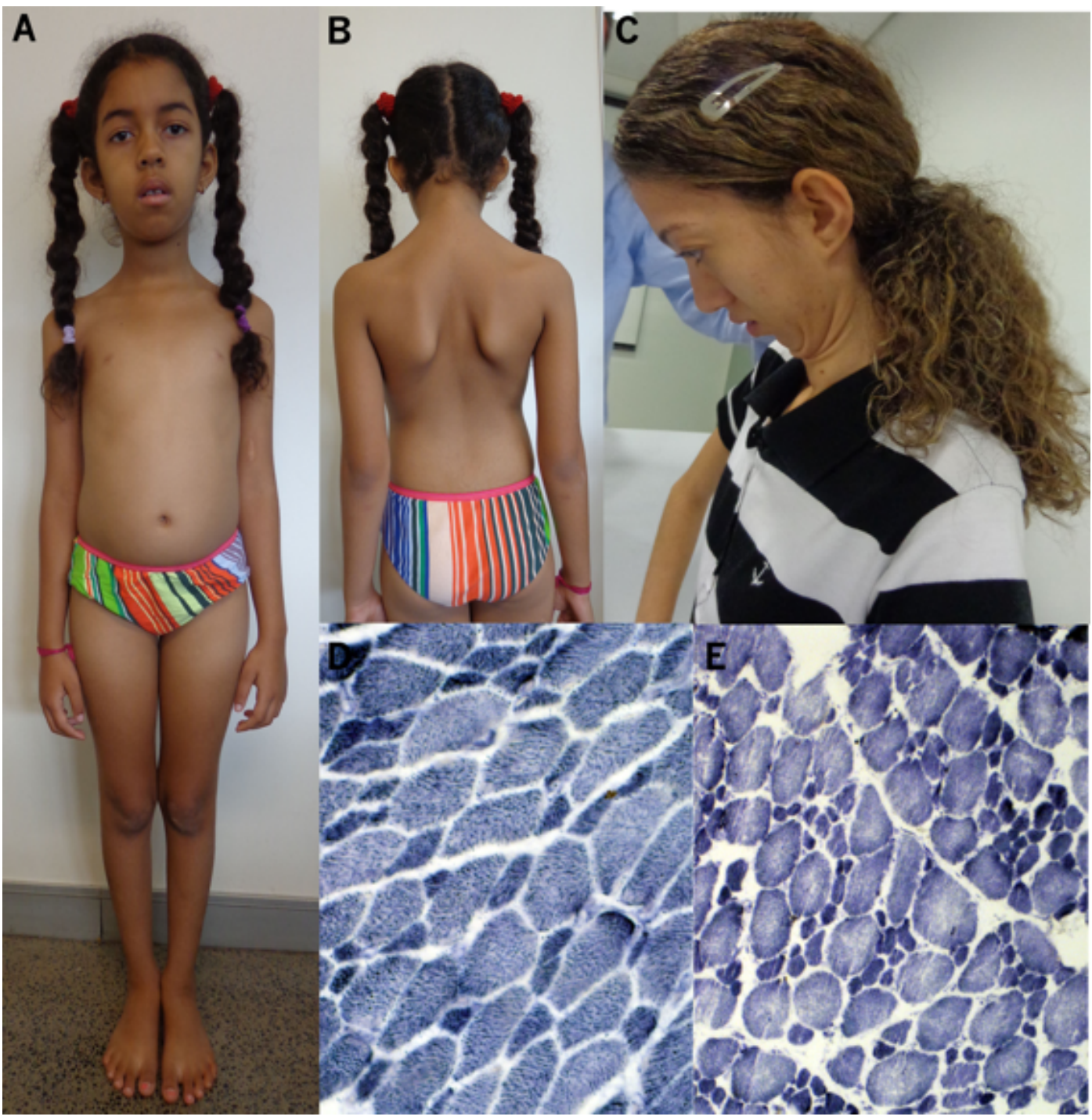

Figura 14 - Pacientes com variantes patogênicas no gene TPM3. A e B) Face miopática, hipotrofia de predomínio proximal deformidade torácica, escápula alada e cifoescoliose no paciente 23.1. C) Limitação e fraqueza em flexores do pescoço na paciente 25.1. D e E) Desproporção de tipo de fibras com fibras do tipo 1 mais que $50 \%$ menores que as fibras tipo 2 sem falhas focais de arquitetura interna ou outras alterações estruturais nos pacientes 23.1 (D) e 25.1 (E) (NADH-TR, 40x). 


\subsubsection{Pacientes com mutação no gene $R Y R 1$}

Encontramos na coorte dois pacientes com variantes em heterozigose composta com alta predição de patogenicidade no gene $R Y R 1$ através do painel para doenças neuromusculares (28.1) e SE (27.1).

O paciente 27.1 é do sexo masculino, segundo filho de pais não consanguíneos sem história familiar de miopatia ou de outras doenças neuromusculares. Nasceu hipotônico e apresentava dificuldade para sugar e perda de peso. Não apresentou atraso dos marcos motores nem atraso de linguagem, mas a marcha era instável, não conseguia se levantar do chão ou subir degraus. O quadro motor foi estável, no entanto, evoluiu com distúrbio ventilatório restritivo grave e iniciou o uso de suporte ventilatório binível ainda na adolescência. Foi avaliado aos 24 anos sem infecções respiratórias recorrentes, deambulava mais que $1000 \mathrm{~m}$ no plano e necessitava de apoio unilateral para subir degraus. Apesar do bom desempenho escolar, concluiu apenas o ensino médio. Ao exame apresentava face miopática, hipotrofia generalizada, fraqueza de predomínio proximal leve nos membros superiores e inferiores, e envolvimento axial moderado. Não apresentava retrações tendíneas, mas apresentava limitação para flexão do tronco e fraqueza cervical. Os exames complementares mostraram valores normais de CPK, ENMG com padrão miopático, espirometria com distúrbio ventilatório grave e exames cardiológicos normais.

Foi realizado estudo do gene SEPN1 por causa da espinha rígida seguido de SE, que detectou duas variantes em heterozigose no gene $R Y R 1$ (tabela 9) 
com alta predição de patogenicidade. O estudo dos pais ainda é necessário a fim de confirmarmos a transmissão e a posição das variantes.

A paciente 28.1 é do sexo feminino, filha única de pais não consanguíneos, nascida pré-termo (36 semanas), apresentou desconforto respiratório logo ao nascer e ficou na UTI por 5 dias. Era hipotônica e tinha dificuldade para sugar. Iniciou investigação aos 3 meses por atraso do sustento cefálico e hipotonia. Sustento cefálico foi obtido aos sete meses, sentou com apoio aos oito e andou aos 24 meses. Aos 30 meses, mantinha dificuldade em subir escadas e não conseguia correr nem pular. Foi avaliada aos 5 anos e apresentava quadro motor estável, apresentou ganhos motores e bom desempenho escolar. Ao exame clínico, apresentou marcha com hiperlordose, báscula de quadril e levantar miopático. A inspeção apresentava face miopática, ptose palpebral, palato ogival e oculomotricidade normal. Possuía fraqueza muscular de predomínio proximal, pior nos membros inferiores e reflexos tendinosos profundos hipoativos. Nos exames complementares apresentou valores séricos normais de CPK e aldolase. Realizou três eletroneuromiografias que estavam normais. Ainda não realizou espirometria. A biópsia muscular foi realizada no segundo ano de vida, apresentando aumento da variabilidade do tamanho das fibras, aumento discreto de tecido conjuntivo, predomínio de fibras tipo 1 e alterações focais da atividade oxidativa, com formações core-like. Foi realizado estudo molecular através de painel com cobertura para genes envolvidos em doenças neuromusculares, no qual foram detectadas duas mutações em heterozigose no gene $R Y R 1$ com alta predição de patogenicidade (tabela 9). O estudo dos pais ainda é necessário a fim de confirmarmos a transmissão e a posição das variantes. 

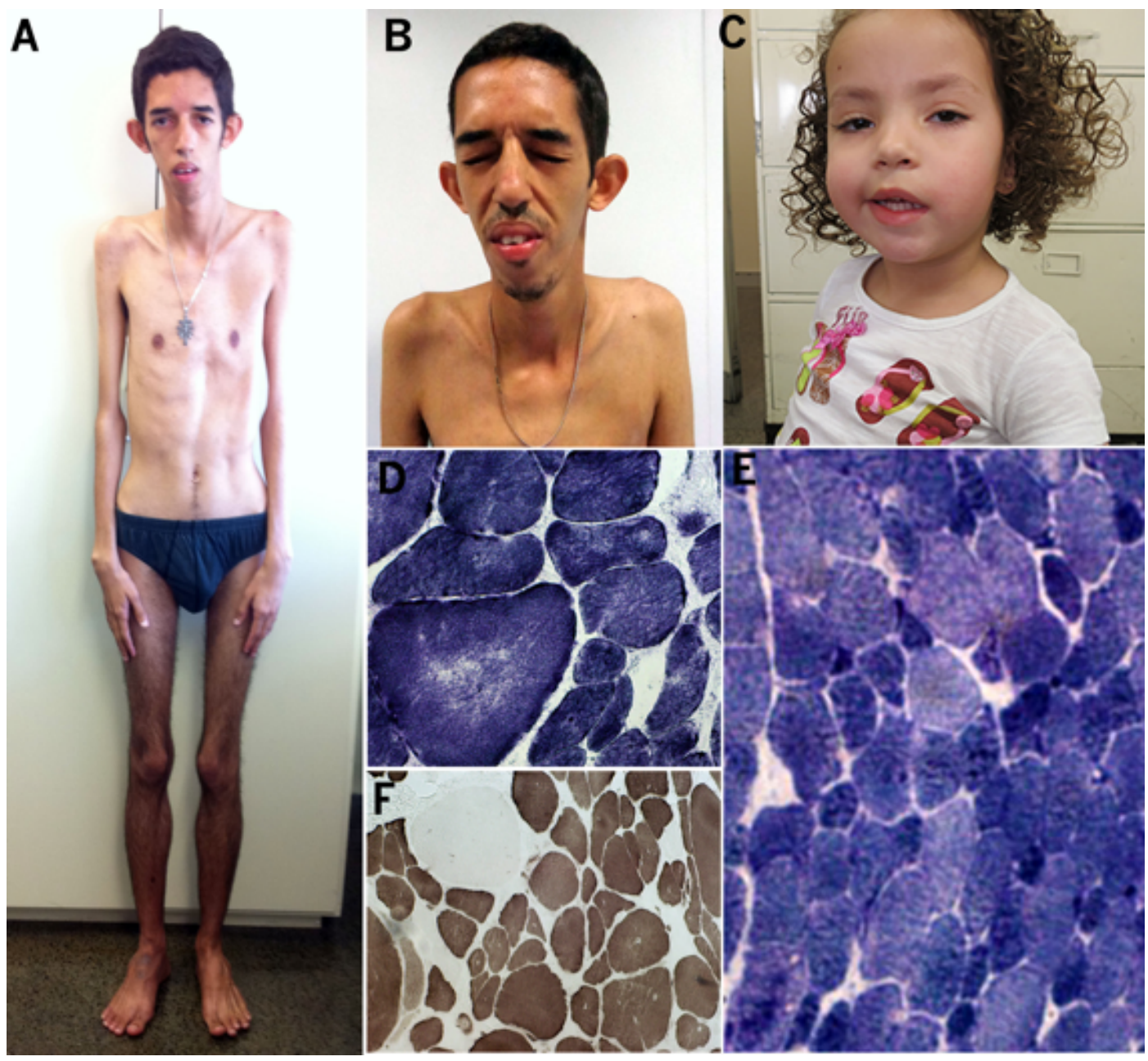

Figura 15 - Pacientes com variantes patogênicas no gene RYR1. A e B) Hipotrofia difusa, deformidade torácica e face miopática no paciente 27.1. C) face miopática e ptose palpebral no paciente 28.1. Aumento da variabilidade do tamanho das fibras com presença de falhas focais (core-like) (NADH, 40x). (D) Predomínio e atrofia de fibras tipo 1 (ATPase 4.6) (F) na biopsia muscular do paciente 27.1. Aumento da variabilidade do tamanho das fibras com presença de falhas focais (core-like) e aumento da atividade oxidativa no interior de algumas fibras $(\mathrm{NADH}, 40 \mathrm{x})$ na biopsia muscular da paciente $28.1(\mathrm{E})$. 


\subsubsection{Paciente com mutação no gene TTN}

O paciente 31.1 é do sexo masculino e foi avaliado aos 13 anos. Apresentou hipotonia neonatal e atraso na aquisição dos marcos motores com sustento cefálico aos 6 meses, sentou aos sete e andou aos 18 meses. Evoluiu com ganhos motores, no entanto, com quedas frequentes e infecções respiratórias de repetição. Tinha dificuldade maior para se levantar do chão, subir escadas, correr e pular, mas evoluiu com melhora destas queixas ainda na primeira década. Ao exame apresentou marcha com leve báscula de quadril e sinal de Gowers. A inspeção observamos palato ogival, hipotrofia e hipotonia global, postura em hiperlordose e escápula alada. O paciente não apresentava dismorfismos faciais, ptose palpebral ou oftalmoparesia. Ao exame de força, o paciente apresentou uma fraqueza proximal leve em membros inferiores e superiores.

Quanto aos exames complementares, apresentou valores normais de CPK, espirometria, eletroneuromiografia, ecocardiograma e eletrocardiograma, todos normais. A biópsia muscular foi realizada aos 4 anos e evidenciou apenas achados leves e inespecíficos como aumento da variabilidade do tamanho das fibras, aumento de tecido conjuntivo e discretas falhas focais de atividade oxidativa. Foi submetido ao SE que detectou duas variantes em heterozigose no gene TTN, sendo uma frameshift e outra em códon de parada (tabela 9). Estas mutações possuem um alto escore de patogenicidade conforme programas específicos e não são encontradas na população de acordo com bancos de exoma consultados (Exac). Devido ao alto número de polimorfismos que este gene apresenta e a sua e alta tolerabilidade a mutações foi realizada RM de corpo inteiro que mostrou acometimento simétrico de vasto lateral e intermédio 
no compartimento anterior e acometimento grave e seletivo de semitendinoso em compartimento posterior da coxa e acometimento moderado e simétrico de sóleo na perna.

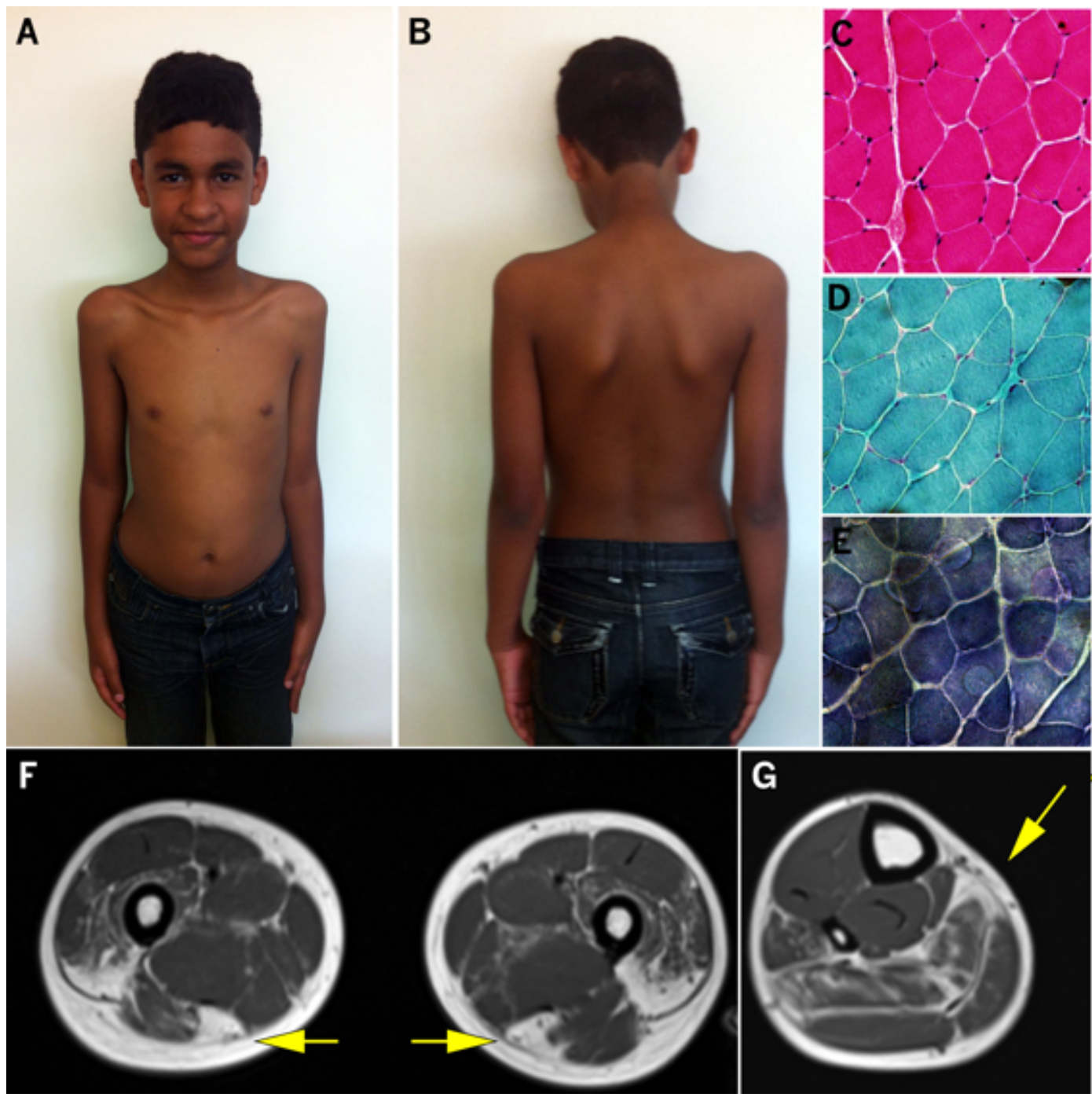

Figura 16 - Paciente com MCl e mutação no gene TTN (Paciente 31.1). A: quadro clínico leve com hipotrofia sem envolvimento facial. B: escápula alada. C: biópsia muscular mostrando leve aumento da variabilidade do tamanho das fibras (HE,40x). D: Biópsia muscular com discreto aumento de tecido conjuntivo (GOM,40x). E: biópsia muscular com leves falhas focais de atividade oxidativa no $(\mathrm{NADH}, 40 \mathrm{x})$. F: RM de coxa (T2WI) mostrando acometimento simétrico de vasto lateral e intermédio no compartimento anterior e acometimento seletivo de semitendinoso em compartimento posterior (setas) das coxas. G) RM de perna evidenciando acometimento do músculo sóleo (seta) com preservação do compartimento anterior. 


\subsubsection{Pacientes com variante patogênica no gene $M Y H 7$}

Encontramos mutações em heterozigose no gene MYH7 em três pacientes com fenótipo de Miopatia Distal de Laing $(39.1,40.1,41.1)$ e uma mutação com padrão em mosaico no paciente 40.2 , pai do paciente 40.1 , que apresenta um fenótipo leve de fraqueza proximal e distal assimétrica provavelmente relacionada ao mosaicismo.

O paciente 39.1 é do sexo masculino, foi avaliado aos 12 anos e apresentou-se com fraqueza para a flexão do pescoço notada pelos pais aos 10 meses de vida. Negou atraso motor, no entanto, andava com os pés evertidos e fez uso de órtese nos pés até os 4 anos. Aos 6 anos o paciente começou a apoiar a cabeça com a mão e para andar e evoluiu com piora da fraqueza cervical, deformidade espinhal e piora do padrão da marcha. Ao exame clínico foi observada fraqueza e atrofia na musculatura cervical e nas porções distais dos membros inferiores, hipotonia e hiporreflexia. Apresentava grave limitação para todos os movimentos do pescoço, cifose toracolombar, desvio ulnar dos punhos, fraqueza nos músculos extensores da mão e dos dedos poupando parcialmente a extensão do segundo dedo. Os músculos mais afetados ao exame clínico foram: flexores cervicais, tríceps, extensores do punho e extensores dos dedos nos membros superiores. Nos membros inferiores os músculos mais afetados foram: extensores do quadril, adutores da coxa, dorsiflexores dos pés e eversores dos pés (bilaterais e simétricos).

Seus exames complementares evidenciaram valores normais de CPK. Espirometria e exames cardiológicos estavam normais. Realizou duas eletroneuromiografias, sendo uma delas miopática e outra neurogênica. A 
biópsia muscular, realizada aos 10 anos, evidenciou achados leves e inespecíficos com atrofia de fibras tipo 1 e alterações da arquitetura interna da fibra tipo multi-minecores. Em decorrência do seu quadro atípico foi submetido ao SE onde foi encontrada variante missense em heterozigose no exon 34 do gene MYH7.

O paciente 40.1, sexo masculino, foi avaliado aos 10 anos de idade. Iniciou com quedas frequentes aos 18 meses sem atraso dos marcos motores ou de linguagem. Evoluiu com escoliose, alteração da marcha e fraqueza nos membros inferiores mais evidente a partir dos seis anos de idade. Realizou uma biópsia muscular aos 10 anos, na qual observamos achados leves e inespecíficos com predomínio total de fibras tipo 2. O seu exame clinico era semelhante ao do paciente 39.1 evidenciando um acometimento axial e distal proeminente, por isso foi optado por realizar o sequenciamento do exon 34 do mesmo gene, que encontrou outra variante com localização próxima da primeira.

O paciente 40.2 é o pai do paciente 40.1 . Foi avaliado aos 43 anos com história de quedas frequentes desde os 7 anos. Ao exame clínico apresentou fraqueza leve distal nos 4 membros. No sequenciamento Sanger do exon 34 foi encontrada a mesma mutação do paciente 40.1, porém com padrão em mosaico confirmando transmissão autossômica dominante.

A paciente 41.1 foi avaliada aos 35 anos era terceira filha de prole de três com pais não afetados. Iniciou o seu quadro clínico com quedas frequentes aos 4 anos. Evoluiu com dificuldade de subir degraus, dificuldade em manusear certos objetos com as mãos e cifoescoliose aos 10 anos que estabilizou aos 18 . Foi submetida a cirurgia corretiva na coluna aos 24 anos e perdeu a marcha aos 
33 anos. Ao exame clínico apresentava fraqueza generalizada com envolvimento predominante em flexores do pescoço, adutores e abdutores do ombro e tríceps nos membros superiores, e os músculos flexores do quadril, extensores do quadril e dorsiflexores dos pés e dos dedos poupando o extensor do hálux. Os exames complementares realizados evidenciaram valores normais de CPK, espirometria com distúrbio ventilatório moderado, ENMG miopática e exames cardiológicos normais. Realizou 3 biópsias musculares sendo a primeira realizada no nosso serviço com DCTF e alterações focais da arquitetura interna (core like). Realizou um painel para doenças neuromusculares que detectou as duas variantes missense no exon 34 do gene MYH7. O seu filho foi testado para a mutação e não apresenta nenhuma das variantes confirmando que ambas estão na mesma fita de DNA.

No intuito de se investigar o quadro atípico apresentado por estes pacientes, foi realizada RM de músculo dos 4 pacientes. Os grupos musculares mais afetados nos membros inferiores nos pacientes 39.1, 40.1 e 40.1 foram tibiais anteriores, extensores longo dos dedos e peroneal. Os músculos glúteos médios também estavam acometidos e os adutores foram gravemente afetados na paciente 41.1, moderadamente afetados no paciente 39.1 e levemente afetado no paciente 40.1 . 

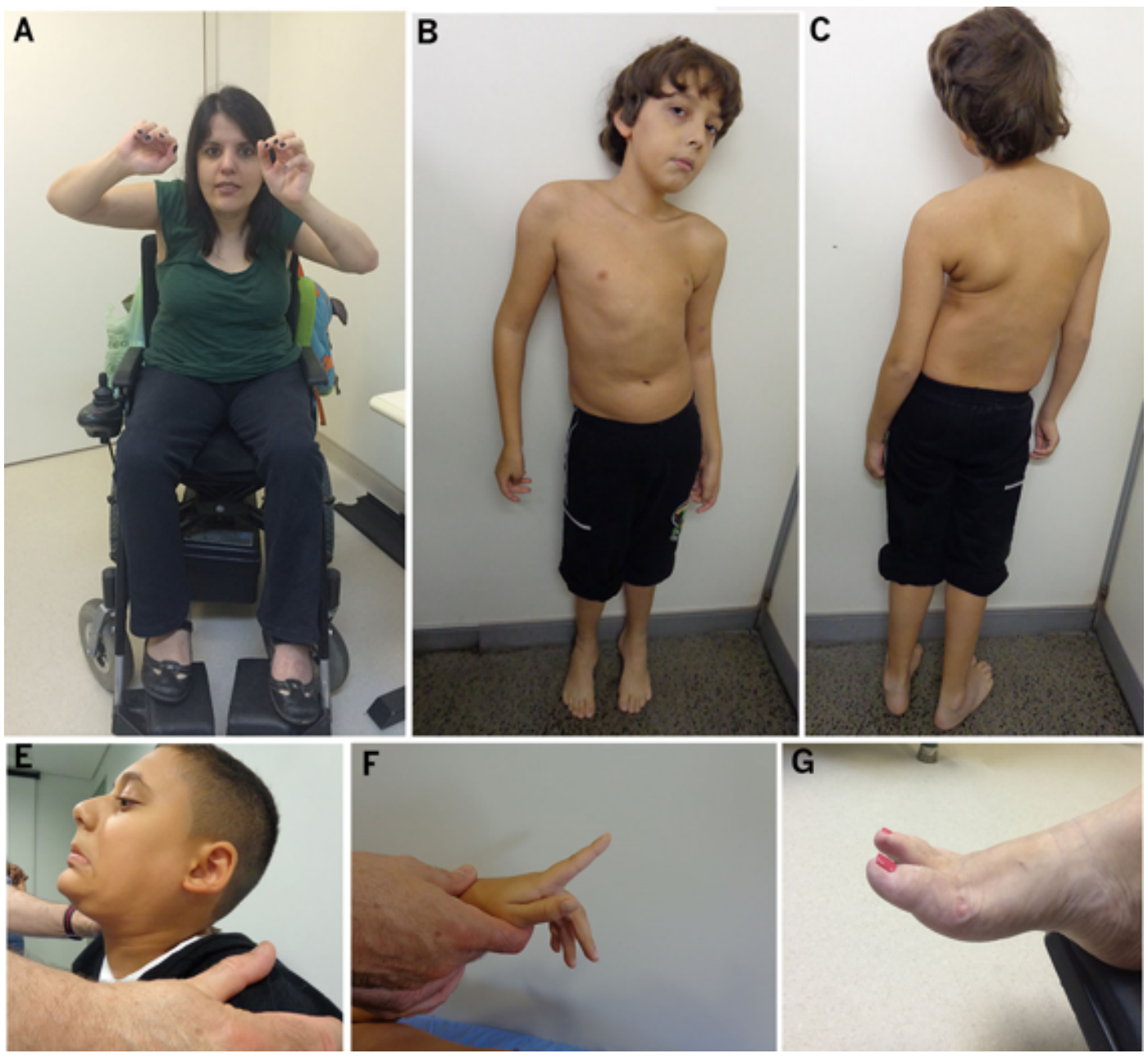

Figura 17 - Pacientes com $\mathbf{M C l}$ e mutação no gene $\mathbf{M Y H 7}$. A) Fraqueza proximal na paciente 41.1. B e C) Envolvimento axial precoce com deformidade torácica e cifoescoliose no paciente 40.1. E) Fraqueza cervical no paciente 39.1. F) Fraqueza dos extensores dos dedos poupando dedo indicador no paciente 39.1. G) Fraqueza dos extensores dos dedos pior no hálux (sinal do "hálux caído") no paciente 41.1. 

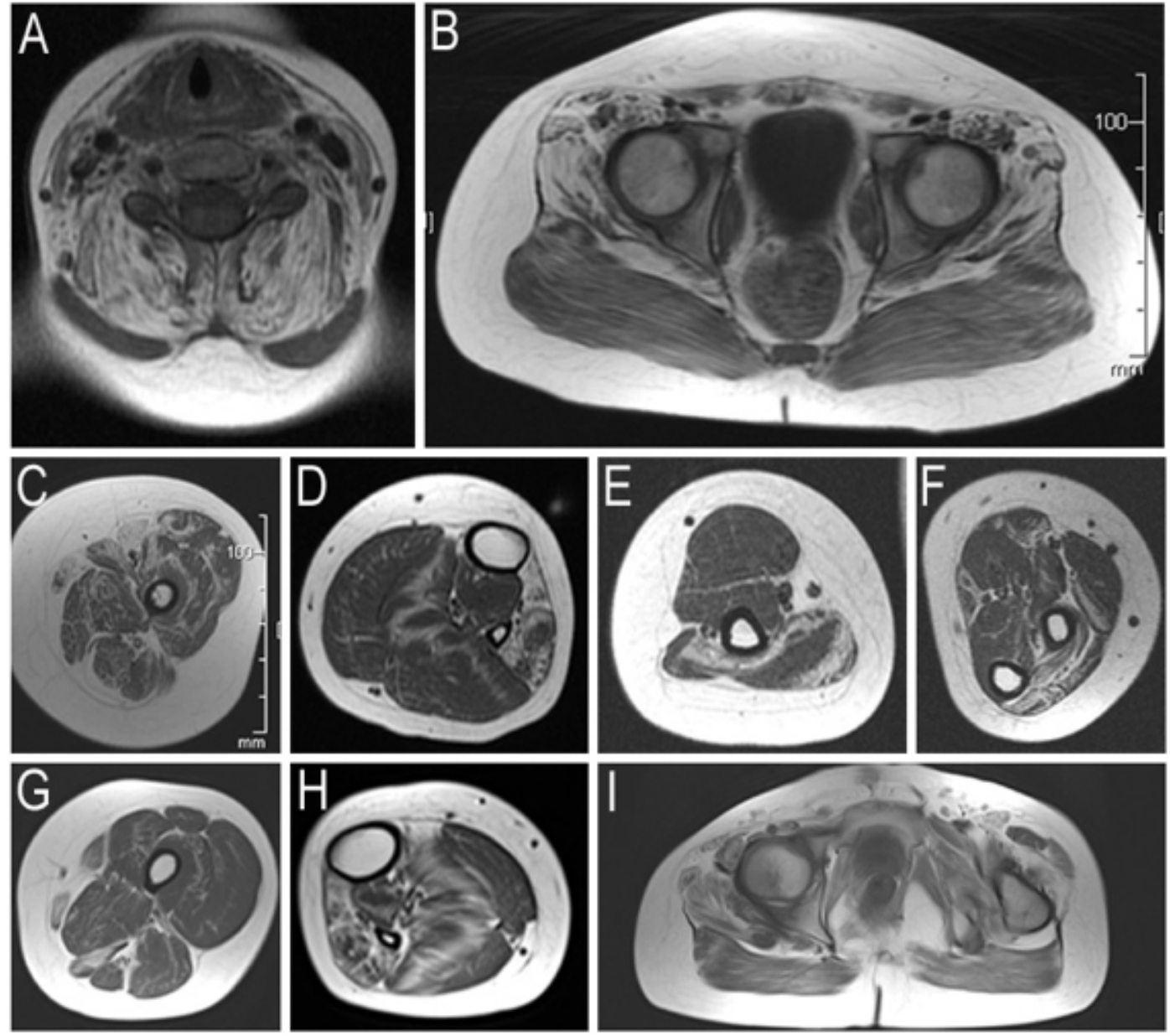

Figura 18 - RM de músculo imagem pesada em T1 dos pacientes 38.1 e $39.1 \mathrm{com}$ mutação no exon 34 do gene $M Y H 7$. A) intensa substituição gordurosa e atrofia muscular nos músculos paraespinhais cervicais no paciente 38.1. B e I) intensa substituição gordurosa no glúteo médio e moderado envolvimento do glúteo máximo no paciente 38.1 e 39.1 respectivamente. C e G) intensa substituição gordurosa no sartório e grácil e leve a moderada nos músculos da coxa nos pacientes 38.1 e 39.1, respectivamente. $\mathrm{D}$ e $\mathrm{H}$ )Intensa substituição gordurosa nos músculos tibial anterior, moderado em peroneal e sóleo, poupando gastrocnêmio medial nos pacientes $38.1 \mathrm{e}$ 39.1, respectivamente. E e F) moderado envolvimento do tríceps poupando o bíceps nos pacientes 38.1 e 39.1 , respectivamente. 

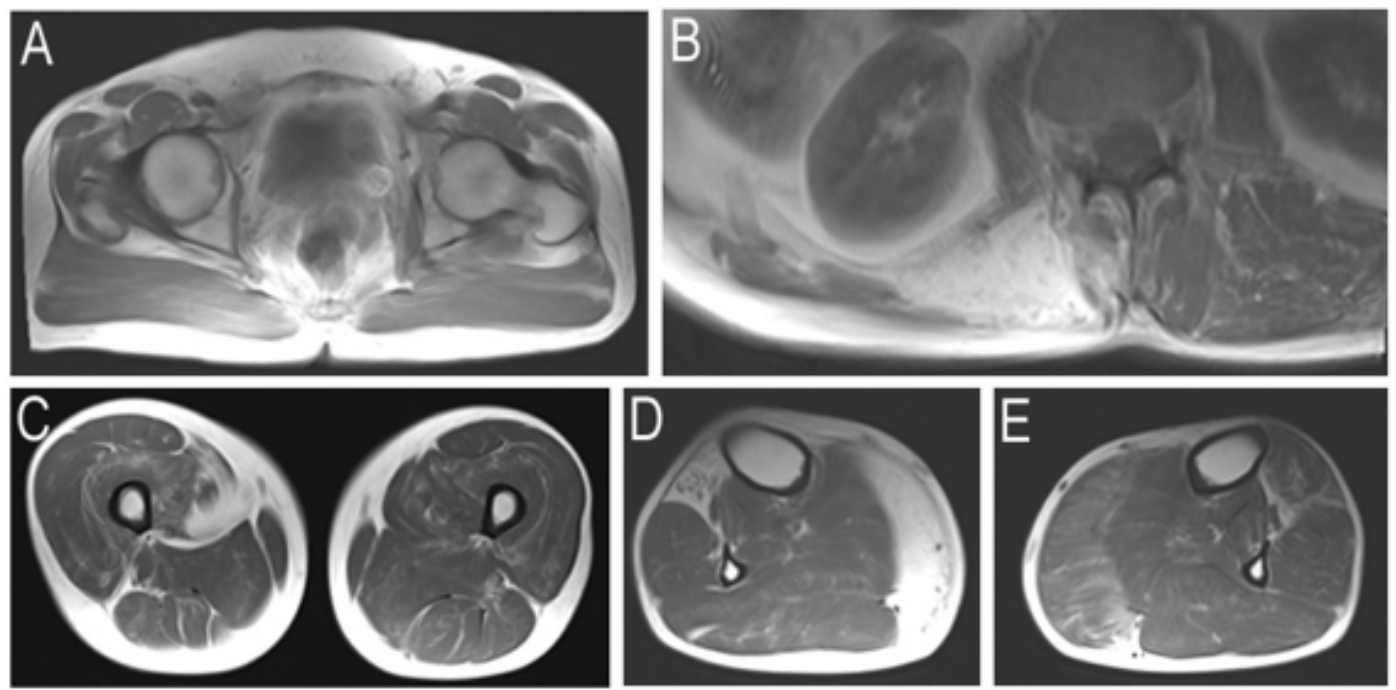

Figura 19 - RM de músculo imagem pesada em T1 do paciente 39.2 com mutação em mosaico no exon 34 do gene MYH7. Envolvimento intenso e assimétrico do glúteo médio a esquerda (A) e ileopsoas (B). Envolvimento leve da musculatura da coxa (C). Intensa substituição gordurosa no tibial anterior e gastrocnêmio medial a esquerda (D) comparada ao moderado acometimento a direita $(E)$. 


\section{DISCUSSÃO}

Neste trabalho estudamos uma coorte brasileira de pacientes com miopatia nemalínica e de pacientes com miopatia congênita com achados inespecíficos na biópsia muscular.

A coorte de pacientes com MN foi de certa forma uniforme. Apresentamos o quadro clinico e histológico de 20 famílias, sendo que, uma apresentou a forma infantil intermediária, 18 apresentaram a forma típica e uma apresentou a forma infantil tardia. Não houve nenhum paciente com a forma neonatal grave. Este fato pode estar relacionado as altas taxas de mortalidade que é encontrada em todas as formas de miopatia congênita com início grave e precoce. Cerca de $10 \%$ dos pacientes vão a óbito ainda dentro do primeiro ano de vida, em decorrência, na maioria dos casos, de infecções respiratórias (Colombo et al., 2015; Wallgren-Pettersson et al., 2004).

Os principais achados clínicos como história perinatal, envolvimento respiratório e bulbar neonatal, atraso nas aquisições dos marcos motores, melhores habilidades motoras, período do aparecimento das complicações ortopédicas e respiratórias e evolução do quadro motor, estavam de acordo com a literatura (Colombo et al., 2015).

A forma infantil intermediária é caracterizada por hipotonia neonatal grave e pela necessidade de suporte ventilatório precoce como ocorreu no paciente 7.1. A forma típica é caracterizada pelo seu início no período neonatal, hipotonia e fraqueza muscular precoces, sinais estes, que foram encontrados em todos os 20 casos (18 famílias) da nossa coorte. Em todos os pacientes com esta forma de apresentação ocorreu atraso importante na aquisição dos marcos motores, 
marcante principalmente no sustento cefálico (maior que 12 meses na maioria dos pacientes) e na aquisição da marcha (maior que 24 meses na maioria dos pacientes). Infecções respiratórias de repetição nos primeiros anos de vida, disfagia, sucção débil e dificuldade em ganhar peso também foram relatados na maioria dos nossos casos. A maioria dos pacientes evoluíram com ganhos motores e estabilidade do quadro motor na primeira década de vida. O início da adolescência, por outro lado, foi marcado pelo surgimento de deformidades osteoesqueléticas e distúrbio ventilatório restritivo, associados diretamente a limitação funcional.

Outro sintoma que se destacou neste grupo de pacientes foi a dificuldade para deglutir. Envolvimento significante da musculatura bulbar levando a dificuldade de sugar e engolir é um achado proeminente na MN (North et al., 2014). A maioria dos pacientes com a forma típica e intermediária de $M N$ apresentou no período neonatal sucção débil, engasgos e pneumonia aspirativa. Muitos destes, inclusive, necessitaram de sonda nasoenteral e/ou gastrostomia nos primeiros meses de vida. A queixa de engasgos frequentes, dificuldade em ganhar peso e uma duração maior do que 30 min por refeição sugerem disfagia, no entanto, não foi realizada uma avaliação sistemática da deglutição. Sugerimos que este seja um ponto a ser abordado em outros estudos, visto ser um fator com alto impacto na evolução destes doentes.

Os bastões nemalínicos são os achados característicos da MN. O seu número varia por fibra, por músculo e pela sua distribuição na fibra. Podem estar localizados dentro do núcleo, estritamente em fibras tipo 1, agrupados na periferia da fibra, alinhados ou distribuídos difusamente pela fibra. Não existe um número mínimo a ser encontrado por biópsia, mas devem ser os achados 
principais para que seja estabelecido o diagnóstico (North et al., 2014). Corpos nemalínicos com localização intracitoplasmática e subsarcolemal foram detectados em todos os pacientes da coorte de MN. Outros achados frequentes na biópsia muscular foram: predomínio de fibras do tipo 1, predominância total de fibras tipo 1, aumento do tecido conjuntivo e aumento da variabilidade entre as fibras. Necrose e aumento do número de centralizações não foram detectados. Reforçando dados da literatura, a quantidade de bastões intracitoplasmáticos e a percentagem de fibras musculares em que são encontrados não se correlacionou com o quadro clínico e não se mostrou um marcador prognóstico (Romero et al., 2013; Wallgren-Pettersson et al., 2011). No entanto, alguns achados como bastões intranucleares e agregados proteicos filamentosos podem ser considerados fatores de mau prognóstico (WallgrenPettersson et al., 2011), o que foi observado nos pacientes com mutações no gene ACTA1. Encontramos bastões nemalínicos intranucleares no paciente 13.1 e agregados proteicos filamentosos no paciente 12.1. Ambos evoluíram com piora progressiva da fraqueza muscular, deformidades osteoesqueléticas graves, retrações tendíneas e piora do distúrbio respiratório logo no início da adolescência. Nossos achados reforçam os relatados na literatura e reforçamos, portanto, que a presença destes na biópsia muscular seja preditiva de mau prognóstico. A monitorização rigorosa da função respiratória e cuidados preventivos para deformidades esqueléticas nestes pacientes é fundamental e contribui com o aumento da sobrevida destes doentes. Observamos também que os pacientes com aumento do tecido conjuntivo e uma maior variabilidade no tamanho das fibras na biópsia, ou seja, um padrão distrófico em associação com os bastões, foram os pacientes com evolução mais desfavorável. 
Alguns pacientes realizaram mais de uma biópsia e não foi constatado mudanças significativas das alterações histológicas. Tal fato sugere que a doença seja estável, ou lentamente progressiva, também do ponto de vista histológico. No entanto, estudos que avaliem a evolução histológica indivualizando cada gene envolvido, são necessários para conclusões mais assertivas.

O diagnóstico molecular nas miopatias nemalínicas é complexo. Até o momento 11 genes foram associados a esta doença e apesar da ampla cobertura dos sequenciamentos de nova geração, muitos casos ainda permanecem sem diagnóstico molecular confirmado (Seferian et al., 2016). Enviamos amostras de todas as famílias de $M N$ nas quais não foram encontradas variantes patogênicas no gene ACTA1, para o SE. Recebemos e analisamos o resultado apenas de seis famílias. Desta forma, confirmamos o diagnóstico molecular em 7 famílias, sendo 4 com variantes no gene ACTA1 e 3 no gene $N E B$, duas famílias ainda permanecem sem confirmação diagnóstica mesmo após o exoma e ainda estamos aguardando o resultado do restante das famílias.

O gene mais frequentemente associado a MN é o NEB, principalmente nos pacientes com padrão de herança recessivo (Lehtokari et al., 2014). Este gene é muito grande, o que dificulta seu estudo pelo método Sanger. Por isso, sugerimos que, nos pacientes com evidente padrão de herança recessivo, técnicas de NGS devam ser utilizadas na primeira etapa do estudo genético. $\mathrm{Na}$ nossa coorte encontramos até o momento variantes no gene NEB em 3 famílias. Duas famílias apresentaram duas variantes em heterozigose (provável hetorozigose composta) com alta predição de patogenicidade. Nenhuma delas 
era consanguínea, mas em uma delas (família 1) encontramos mais de um irmão afetado. Nesta família, encontramos apenas uma variante com alta predição de patogenicidade no gene NEB. Após a análise de cobertura dos exons no arquivo BAM foi constatado que dez exons não são bem cobertos. Consideramos o gene NEB ainda assim como sendo o candidado para esta família, mas a análise destes exons e o estudo dos pais ainda é necessário. Os quatro pacientes apresentaram a forma típica de apresentação, e exceto o paciente 9.1 , os pacientes apresentaram distúrbio ventilatório restritivo com início de suporte ventilatório precoce, ainda na primeira década. Os quatro pacientes apresentavam boa força apendicular (MRC de grau IV) com grave envolvimento de flexores do pescoço e dorsiflexores dos pés. A biópsia muscular destes pacientes apresentou bastões subsarcolemais e intracitoplasmáticos com discreto aumento de tecido conjuntivo. Achados estes correspondentes aos encontrados na literatura tanto do ponto de vista clínico quanto histológico (Romero et al., 2013).

O gene ACTA1 é o mais frequente gene associado a MN dentre os casos de transmissão dominante, mas casos recessivos já foram relatados na literatura (O'Grady et al., 2015). É responsável por até $25 \%$ dos casos com a forma típica de apresentação e até $50 \%$ dos casos com formas clínicas grave (Laing et al., 2009). Das 20 famílias com MN, mutação no ACTA1 foi encontrada em 4 casos (20\%), todas missense, em heterozigose e já associadas previamente a MN (Laing et al., 2009; Sparrow et al., 2003).

Observamos, portanto, que o gene ACTA1 pode estar associado a diferentes fenótipos de MN com gravidade variando de formas graves a quadros leves. No entanto, existem alguns achados histológicos, como a presença de agregados 
de actina e bastões intranucleares, que são encontrados apenas neste quadro molecular e ainda são preditivos de mau prognóstico. De uma forma geral, este gene é muito conservado e variantes missense tem alta predição de patogenicidade. A localização da mutação parece determinar entre fenótipos com bastões nemalinicos clássicos e presença de agregados filamentares de actina e bastões intranucleares. Mutações no gene ACTA1 podem resultar no comprometimento da ligação entre a actina e as proteínas ligadoras de actina ou na própria interação actina-actina. A miopatia com agregados de actina é mais especificamente relacionada a mutações localizadas nos subdomínios um e três próximos ao acotovelamento. Enquanto que as variantes relacionadas a formações de bastões intranucleares estão mais relacionadas a superfície de alfa-hélix da proteína (Feng et al., 2009; Laing et al., 2009; Sparrow et al., 2003).

Com relação as famílias com mutação no ACTA1, observamos uma importante variabilidade fenotípica e histológica, a qual é normalmente atribuída a este gene (Feng et al., 2009). Dois pacientes apresentaram a forma típica de MN com bastões subsarcolemais, um paciente apresentou bastões intranucleares e um paciente apresentou MN com agregados proteicos de actina.

Nos pacientes com MN com bastões subsarcolemais, 6.1 e 17.1, observamos a forma típica de apresentação e quadro motor com tendência a estabilidade. Foram encontrados bastões predominantemente subsarcolemais em 100\% das fibras e discreto aumento de tecido conjuntivo no paciente 17.1 e bastões intracitoplasmáticos e proeminente DCTF no paciente 6.1. Ambas as variantes encontradas já foram descritas em pacientes com MN e fenótipo semelhante (Castiglioni et al., 2014; Laing et al., 2009). 
Já o paciente 12.1 apresentou um fenótipo mais grave com piora progressiva após a primeira década que resultou em piora da fraqueza muscular, distúrbio ventilatório e deformidades esqueléticas graves, apresentando importante limitação funcional. A biópsia muscular mostrou um padrão distrófico com a presença de bastões e de agregados intracitoplasmáticos. A variante encontrada já foi associada a miopatia com agregados de actina, um subtipo de actinopatia (Sparrow et al., 2003). Similar ao paciente anterior, o paciente 13.1, que também apresentou um fenótipo mais grave e possuía um aspecto histológico peculiar: bastões intranucleares. A variante encontrada neste paciente também já foi descrita e associada a este fenótipo (Sparrow et al., 2003).

Desta forma concluímos que o gene ACTA1 é um importante candidato nas MN. O quadro clínico dos pacientes, bem como suas peculiares alterações histológicas são diretamente relacionados a posição das mutações no gene e o conhecimento da sua estrutura é muito importante. E ainda a presença de bastões intranucleares e/ ou agregados filamentosos de actina são apresentações específicas deste gene e são valiosos marcadores prognósticos.

O gene TPM3 foi o primeiro gene a ser descrito e associado a MN, também está relacionado a formas dominantes da doença, sendo responsável por cerca de $5 \%$ dos casos (Laing et al., 1995). Também é um importante candidato no estudo das miopatias com DCTF (N. F. Clarke et al., 2008), que será discutido mais adiante. A grande maioria dos pacientes com MN com mutação no gene TPM3 apresenta, na biópsia muscular, um aumento da variabilidade no tipo de fibras com presença de bastões apenas em fibras tipo 1 (North et al., 2014). Estes achados histológicos foram observados apenas em um paciente, no entanto, não foi encontrada nenhuma variante nos exons estudados. Por 
dificuldades técnicas, o exon 1 não foi sequenciado. Desta forma a variante no gene TPM3 continua sendo considerada para este paciente e estamos aguardando o resultado do SE.

$\mathrm{O}$ grupo dos pacientes com $\mathrm{MCl}$ representou um grande desafio neste trabalho. A inespecificidade dos achados clínicos e histológicos dificultou a identificação de genes candidatos. Na tentativa de facilitar o estudo, dividimos estes pacientes clinicamente em três grupos, achados leves e inespecíficos, espinha rígida e quadro atípico, na tentativa de dirigir o estudo molecular.

No primeiro grupo, composto por 7 famílias, foi realizado o sequenciamento dos genes ACTA1 e TPM3. Não foram encontradas variantes nestes genes para este grupo de pacientes. Destes, quatro foram enviados para o SE. Foram analisados os resultados dos pacientes 21.1 (variante patogênica no gene CHRNE), 31.1 (duas variantes em heterozigose no gene TTN), e 33.1 na qual não foi detectada variante candidata.

As síndromes de miastenia congênita (SMC) compreendem um grupo tradicionalmente classificado pelo sítio do defeito da transmissão neuromuscular, podendo ser pré-sinápiticas, sinápticas e pós-sinapticas, sendo estas, as mais frequentes (Engel et al., 1998). Os receptores de acetilcolina na junção neuromuscular são compostos por quatro subunidades com duas subunidades alfa (CHRNA1), uma beta (CHRNB1), uma epsilon (CHRNE) e uma delta (CHRND). O gene CHRNE codifica a subunidade épsilon e esta, assim como as outras subunidades, é uma região muito conservada nos mamíferos. Variantes neste gene tendem a ser patogênicas e estão relacionadas a um subtipo de miastenia congênita pós-sináptica (Kinali et al., 2008). A paciente 31.1 possui a 
variante c.136dupC no gene CHRNE. Ela apresentou quadro de hipomimia facial, hipotonia neonatal, luxação congênita de quadril e deformidades nos pés. Evoluiu com atraso motor e de linguagem com disfonia. Clinicamente apresentava leve fraqueza muscular com envolvimento facial importante, oftalmoparesia e disfonia, mas sem fatigabilidade clínica. ENMG era normal com teste de estimulação repetitiva normal, o que pode ocorrer nestes casos (Harper, 2004; Lorenzoni et al., 2012).

Os principais achados clínicos da SMC associada ao gene CHRNE são ptose, hipotonia, disfonia e distúrbio da deglutição (Lorenzoni et al., 2012) compatíveis com o fenótipo apresentado pela nossa paciente. A fraqueza muscular pode variar de leve a grave e sintomas dinâmicos como fatigabilidade podem não estar presentes ou serem difíceis de reconhecer. Estudos eletrofisiológicos podem não ser conclusivos, mas o teste de fibra única é útil no diagnóstico e ainda não foi realizado na paciente (Engel et al., 2015; Lorenzoni et al., 2012). O tratamento é baseado no uso de drogas inibidoras da colinesterase. O diagnóstico de miastenia congênita e o seu diagnóstico diferencial com miopatia congênita representam um grande desafio para os médicos assistentes visto que o quadro clínico destas desordens se sobrepõe e o estudo eletrofisiológico nem sempre é confirmatório. Reforçamos, portanto, a importância de um estudo molecular abrangente neste grupo de doenças principalmente por se tratar de um diagnóstico com um tratamento capaz de ocasionar melhoras expressivas no quadro clínico (Pavone et al., 2013).

O gene TTN possui 363 exons e codifica a proteína sarcomérica titina que é a maior proteína humana. É composta por mais de 38.000 aminoácidos e permanece ancorada aos pares a linha M e linha Z. Atua providenciando a maior 
parte da força passiva e modulando a força ativa na contração muscular (Granzier et al., 1995). A proteína titina possui propriedades importantes para o mecanismo de contração muscular, sendo responsável por manter a estrutura do sarcômero, a elasticidade muscular e ainda por proporcionar sítios de ligação para várias outras proteínas musculares incluindo calpaína-3, alfa-actina, miosina, teletonina e, indiretamente, a miotilina, através de ligações com a alfaactina (Liversage et al., 2001).

Este gene possui vários sítios de splicing alternativo formando isoformas de tamanhos variados presentes no músculo esquelético e cardíaco (Akinrinade et al., 2015; Peled et al., 2014). Estas isoformas podem ser responsáveis pelo envolvimento seletivo de alguns grupamentos musculares observadas em miopatias causadas por mutações neste gene (Hackman, et al 2008).

Vários fenótipos já foram associados ao gene TTN, sendo o mais frequente a distrofia muscular tibial, miopatia autossômica dominante descrita inicialmente em pacientes finlandeses, que se manifesta com fraqueza e atrofia seletiva de músculos do compartimento anterior da perna, principalmente o tibial anterior após a terceira década de vida (Hackman et al., 2002). Outras titinopatias incluem: cardiomiopatia familiar isolada (Gerull et al., 2002), miopatia hereditária com falência respiratória precoce (Palmio et al., 2014), miopatia congênita com cardiomiopatia letal (Carmignac et al., 2007), Emery-Dreifuss juvenil sem cardiopatia (De Cid et al., 2015).

Encontramos na nossa coorte um paciente (31.1) com duas mutações no gene TTN sendo uma delas em códon de parada e a outra frameshift com alta predição de patogenicidade. O paciente iniciou os sintomas no período neonatal. 
Apresentou-se na avaliação com discreta limitação funcional, sem predomínio de envolvimento do compartimento anterior da musculatura da perna ou cardiopatia que seriam esperados para pacientes com mutação neste gene. Foi realizada RM de músculo de corpo inteiro que dentre outros achados evidenciou um comprometimento seletivo do músculo semitendinoso na coxa, achado este já descrito previamente em titinopatias e considerado muito característico (Yue et al., 2015). Apesar das variantes terem alta predição de patogenicidade por truncarem a proteína, concluir que elas são de fato as responsáveis pelo quadro clinico do paciente representou um grande desafio, pelo fato do gene ser muito grande e possuir inúmeros polimorfismos. No entanto, os achados de imagem possibilitaram fortalecer o diagnóstico.

No segundo grupo de $\mathrm{MCl}$, composto por oito famílias com a presença de espinha rígida no exame clínico, foi sequenciado o gene SEPN1. Todos os 13 exons foram estudados e não foi detectada nenhuma variante patogênica neste grupo de pacientes. O gene SEPN1 codifica a proteína selenoproteína que se expressa no músculo esquelético. Os mecanismos fisiopatológicos envolvendo este gene ainda são incertos, mas mutações são uma causa reconhecida de distrofia muscular congênita com espinha rígida (DMCER) (Moghadaszadeh et al., 2001) e doença multi-minicore (DMnC) (Ferreiro et al., 2002). Em ambos os grupos, os pacientes compartilham um quadro predominantemente axial com envolvimento progressivo e precoce da musculatura respiratória e, na maioria dos casos, espinha rígida (Lescure et al., 2009). As mutações já foram descritas ao longo de todo o gene e estão presentes em uma grande proporção de pacientes com miopatias predominantemente axiais, escoliose grave e insuficiência respiratória (Moghadaszadeh et al., 2001), e por esta razão, foi 
estudada neste grupo de pacientes. O que nos chamou atenção é que apesar da espinha rígida, nenhum dos pacientes apresentava alterações compatíveis com miopatia multi-minicore frequentemente associada a este gene (N. F. Clarke et al., 2006), três dos pacientes apresentaram quadro histológico de DCTF e os demais alterações leves e inespecíficas. Outro fato importante é que os pacientes apresentaram um quadro respiratório estável o que seria incomum para paciente com selenopatias.

Após o sequenciamento do gene SEPN1 não ter sido esclarecedor, todos os pacientes foram enviados para o SE. Já foram analisados os resultados de cinco destes e estamos aguardando o resultado dos três restantes. Nestes cinco resultados analisados foram encontradas variantes patogênicas no gene da TPM3 em 2 pacientes (23.1 e 25.1), RYR1 em um paciente (27.1) e não foram encontradas variantes candidatas em dois pacientes.

As tropomiosinas são proteínas coiled coil, ligadoras de actina que são responsáveis pela estabilização da actina e pelas interações entre actinamiosina limitando o acesso aos sítios de ligação da miosina (Gunning et al., 2005). Mutações no gene TPM3, podem estar relacionados a vários fenótipos, sendo, MN (Laing et al., 1995), miopatia com cap (De Paula et al., 2009) e DCTF (N. F. Clarke, 2008), os mais comuns. Um aspecto importante com relação a estes fenótipos é a grande sobreposição de achados clínicos e histológicos que estes fenótipos apresentam. Atrofia e predomínio de fibras tipo 1 podem ocorrer em um amplo espectro de doenças musculares e não musculares, e são achados frequentes nas miopatias congênitas, mas apenas quando essa diferença é de pelo menos 35-40\% é que se considera DCTF (Laing NG, Wallgren-Pettersson C., 2009). Mutações no gene TPM3 são a causa genética mais comum de DCTF, 
sendo responsável por cerca de $30 \%$ dos casos e normalmente seguem padrão de herança dominante, sendo a maioria das mutações, de novo. Quando em homozigose, as variantes estão normalmente localizadas no início ou no término do gene. A maior parte das mutações recessivas são nonsense ou em códon de parada, enquanto que as dominantes são missenses ou deleções que afetam o código de leitura (N. F. Clarke et al., 2008). No grupo de $\mathrm{MCl}$ apenas quatro pacientes apresentaram desproporção de fibras importante, fibras tipo 1 mais que $50 \%$ menores que fibras tipo 2 , e nestes foram encontradas mutações no gene TPM3 em dois.

Encontramos uma variante nova em homozigose na paciente 23.1 e uma variante em heterozigose na paciente 25.1 já descrita na literatura. A paciente 23.1 é filha única de pais consanguíneos (primos de primeiro grau) sem história familiar positiva para miopatia ou outras doenças neuromusculares. O fenótipo apresentado pela paciente foi o de uma miopatia congênita, com achados faciais proeminentes, fraqueza muscular leve e envolvimento axial moderado e biópsia com fibras tipo um mais que $50 \%$ menores que fibras tipo 2 , compatível com DCTF, no entanto, homozigose com os pais portadores assintomáticos é rara. Vamos prosseguir com o estudo molecular dos pais.

Já a paciente 25.1 apresenta um quadro típico de DCTF. Teve manifestações neonatais leves, fenótipo longilíneo, fraqueza muscular leve com proeminente envolvimento axial e espinha rígida. Evoluiu com cifoescoliose, distúrbio ventilatório restritivo grave e precoce na adolescência e necessitou de cirurgia corretiva para cifoescoliose ainda na adolescência, seguido de estabilidade clínica na segunda década de vida. 
Mutações no gene TPM3 são raras e podem estar associadas a fenótipos com gravidade variável. Estudos sugerem que mutações neste gene alteram a interação entre tropomiosina e F-actina (Marttila et al., 2014). Modelos moleculares predizem que a posição Arg168 (envolvida na paciente 25.1 e próxima a variante encontrada na paciente 23.1) está posicionada próximo a uma região hidrofóbica ligadora de F-actina, então acredita-se que a troca de arginina pela histidina, como o que ocorreu com a paciente 25.1, altere a carga no domínio alfa-hélice comprometendo a formação de pontes com aminoácidos polarizados na hélice F-actina (N. F. Clarke, 2008; Durling et al., 2002).

O último grupo de pacientes, composto por 6 famílias, continha apenas quadros atípicos como envolvimento oculofacial, deformidades osteoesqueléticas e pronunciado envolvimento distal. Nestes pacientes encontramos duas variantes em heterozigose no gene RYR1 na paciente $28.1 \mathrm{e}$ variantes missense no exon 34 do gene $M Y H 7$ em três famílias.

Até recentemente, o gene $M Y H 7$ era considerado uma causa incomum de miopatia. Descobertas recentes o apontaram como uma importante causa de miopatia com achados inespecíficos na biópsia muscular. Fato este que foi observado na nossa coorte.

Este gene codifica a cadeia beta pesada da miosina lenta, proteína importante no mecanismo de contração muscular expressa em fibras musculares esqueléticas e cardíacas (Jaenicke et al., 1990). Os mecanismos patogênicos que levam a miopatia ainda não são conhecidos mas sugere-se que mutações no rod domain alterem o sítio de ligação desta proteína e mutações no domínio globular alterem a sua estabilidade (Meredith et al., 2004). A miosina muscular 
é uma proteína altamente conservada, forma um arranjo hexamérico composto por duas subunidades de cadeia pesada de miosina e dois pares de subunidades leves não idênticas. Esta estrutura polarizada é necessária para o seu funcionamento, portanto, a maioria das mutações missenses são patogênicas (Muelas et al., 2010).

Mutações neste gene estão associadas a vários fenótipos dentre eles cardiomiopatia isolada (Witjas-Paalberends et al., 2013), miopatia distal de Laing (Meredith et al., 2004), miopatia com acúmulo de miosina (Tajsharghi et al., 2007), miopatia com cores (Romero et al., 2014) miopatia com corpos serpentiformes e alterações miofibrilares (Tasca et al., 2012) e desproporção congênita de tipo de fibras (DeChene et al., 1993).

Os pacientes, nos quais encontramos mutação no gene $M Y H 7$, possuem quadro clínico compatível com miopatia distal de Laing (MDL), no entanto com um pronunciado e precoce envolvimento axial. Quando sentados adquirem uma postura compensatória com desvio anterior da cabeça o que os deixa com uma postura em "esfinge". MDL é uma miopatia autossômica dominante que pode ter início congênito ou na idade adulta. A principal apresentação clínica é composta por fraqueza nos músculos tibial anterior, extensores longos dos dedos seguido pelos flexores do pescoço, extensores dos dedos das mãos e fraqueza facial. Os pacientes 38.1, 39.1 e 40.1 não apresentaram atraso dos marcos motores, mas tiveram início da fraqueza muscular em musculatura cervical e distal já relatada nos primeiros dois anos de vida. Evoluíram com acometimento da musculatura paravertebral adotando uma marcha e exame clínico característicos. Todos possuíam fraqueza cervical, tríceps mais acometido que o bíceps, extensores do punho e dos dedos mais acometidos que os flexores e 
comprometimento de musculatura anterior da perna. Este padrão pode ser confirmado pelo exame de imagem (RM), ao qual foram submetidos. Um outro aspecto que chamou a atenção é o padrão de acometimento da musculatura afetada na imagem. Observamos um sinal anormal central nos músculos acometidos, principalmente no sóleo, com relativa preservação da periferia. Este sinal fica mais evidente com a progressão da doença e não foi descrito em nenhuma outra miopatia. Histologicamente é caracterizada por achados inespecíficos, sendo os mais frequentes: o aumento da variabilidade no tamanho das fibras com atrofia de fibras tipo 1 e multi-minicores como foi detectado no paciente 38.1 e na paciente 40.1 . Predomínio de fibras tipo 2 , encontrado no pacientes 39.1, também já foi associada a mutações neste gene (N. F. Clarke et al., 2013).

O paciente 39.2 é pai do paciente 39.1 e possui um quadro leve de fraqueza muscular com quedas frequentes desde infância. Detectamos através de sequenciamento Sanger um padrão em mosaico da mutação. Atribuímos, portanto, o fato do seu quadro clínico ter sido mais brando ao próprio mosaicismo. Outro fator de destaque foi a assimetria de acometimento muscular visualizada pelo exame de imagem, provavelmente também causada pelo mosaicismo.

O gene MYH7 é também um importante candidato a cardiopatia hereditária, no entanto, variantes associadas a doença cardíaca se localizam no domínio proximal do gene, o que explica função cardíaca normal nos pacientes com miopatia de Laing. 
O gene $R Y R 1$ codifica o receptor do canal da rianodina que é um canal de sódio no retículo sarcoplasmático. A cada vez que um potencial de ação muscular se propaga ao longo do sarcolema para dentro do túbulo transverso, o canal voltagem dependente (receptor de dihidropiridina - DHPR) é ativado e se abre. Essa mudança conformacional é transmitida ao receptor do canal da rianodina que também se abre em resposta, resultando em liberação de cálcio que por sua vez leva a contração muscular. Alterações nestes receptores são responsáveis por mudanças funcionais na regulação de entrada e saída de cálcio comprometendo a contração muscular.

Mutações no gene RYR1 são classicamente associadas a miopatia central-cores de transmissão dominante, fraqueza de início tardio na infância, rabdomiólise e síndrome de hipertermia maligna. Estudos recentes mostraram que mutações recessivas e algumas dominantes podem resultar em quadros mais graves associados a miopatia multi-minicores, miopatia centronuclear, DCTF e distrofia muscular congênita (Romero et al., 2003).

Foram detectadas mutações em heterozigose composta neste gene em dois pacientes da coorte. Uma delas (28.1) apresentou atraso dos marcos motores com envolvimento facial caracterizado por ptose palpebral sem oftalmoparesia, palato ogival e paresia facial bilateral e simétrica. Está evoluindo com ganhos motores, bom desempenho escolar e discretas limitações funcionais. Apresenta na biópsia um padrão miopático com falhas focais na atividade oxidativa compatível com o gene RYR1. Já o paciente 27.1 apresentou um quadro com envolvimento predominantemente axial com espinha rígida e distúrbio ventilatório grave e precoce. Na biópsia realizada aos 24 anos foi visualizado discreto aumento do tecido conjuntivo, leve aumento da variabilidade 
do tamanho das fibras e falhas de atividade oxidativa compatível com formações core-like, compatível com o diagnóstico molecular.

A variabilidade fenotípica encontrada nos dois pacientes reflete a descrita na literatura, o que reforça a importância do seu estudo em miopatias em que encontramos cores, minicores ou formações core-like, independente do fenótipo clínico apresentado.

Apesar das variantes encontradas não terem sido previamente associadas a síndrome de hipertermia maligna, optamos por sempre orientar os pacientes quanto aos cuidados preventivos para a síndrome, evitando o uso de drogas anestésicas halogenadas e bloqueadores neuromusculares tipo succinilcolina.

Cinco famílias da coorte de $\mathrm{MN}$ e $\mathrm{MCI}$ permaneceram sem gene candidato mesmo após a análise do SE, sendo duas famílias com MN e três com MCl. Para estes pacientes reforçamos a necessidade de repetidas análises no estudo dos casos. Além de falhas técnicas na análise e na desatualização de bancos de dados, ressaltamos a existência de novos genes a serem implicados nas miopatias congênitas o que mostra a importância em se manter o estudo nos casos não concluídos. 


\section{CONCLUSÃO}

1. Os aspectos fenotípicos dos pacientes com $M N$ refletem o descrito na literatura. A maioria dos pacientes manifestaram um quadro clínico de predomínio axial com comprometimento respiratório precoce.

2. Intercorrências neonatais foram comumente apresentadas nos dois grupos de miopatias avaliados, sendo as principais: hipotonia neonatal, dificuldade para sugar e engolir, e comprometimento respiratório.

3. O grupo de $\mathrm{MN}$ apresentou um número maior de pacientes que necessitaram de cuidados intensivos e também um maior tempo de internação quando comparado ao grupo de $\mathrm{MCl}$.

4. Atraso dos marcos motores foi observado na maioria dos pacientes, mas o atraso do sustento cefálico foi mais marcante nos pacientes com MN.

5. Mutações em heterozigose composta no gene NEB foram frequentes em pacientes com $\mathrm{MN}$, em especial naqueles com a forma típica de apresentação e com envolvimento do compartimento anterior da perna.

6. Mutações no gene ACTA1 foram frequentes em pacientes com $\mathrm{MN}$, em especial nas formas dominantes, manifestando-se com grande variabilidade clínica.

7. Na MN, a presença de bastões intranucleares e agregados de actina sugerem mutação no gene ACTA1.

8. Nas miopatias congênitas com alterações leves e inespecíficas, há grande variabilidade clínica e genética.

9. O gene da TPM3 foi o principal candidato nas miopatias congênitas com a presença de desproporção congênita de fibras de mais que 50\% (fibras 
do tipo 2 pelo menos $50 \%$ maiores que fibras do tipo 1). Mutações na TPM3 não foram frequentes na MN.

10. O gene da RYR1 é um importante candidato nas miopatias com alterações mínimas, em especial naqueles com falhas focais da atividade oxidativa proeminentes na biopsia muscular.

11. O gene $M Y H 7$ é um candidato importante nas miopatias com alterações mínimas, em especial naqueles pacientes com proeminente envolvimento distal e axial.

12. O uso de exames de imagem muscular pode auxiliar na interpretação de variantes encontradas no estudo genético, como observado no paciente com mutação no gene da TTN que tinha o característico envolvimento do músculo semimembranoso no exame de RM.

13. Técnicas de sequenciamento de nova geração, incluindo painéis de genes e exoma, são excelentes métodos para investigação de miopatias congênitas, devido ao grande número de genes envolvidos na doença e a análise dispendiosa de muitos destes genes através de métodos convencionais. No entanto, o exame não é capaz de diagnosticar todos os casos. 


\title{
9. ANEXO: FICHA DE ATENDIMENTO PADRÃO DO AMBULATÓRIO DE DOENÇAS NEUROMUSCULARES FMUSP
}

\author{
AMBULATÓRIO DE DOENÇAS NEUROMUSCULARES \\ DISCIPLINA DE NEUROLOGIA INFANTIL (HC-FMUSP)
}

1) IDENTIFICAÇÃO:

Data:

Nome:

Prontuário:

DN: Idade:

Sexo: $M \square \quad F \square$

Procedência:

Escolaridade:

Mãe:

Pai:

Telefone:

E-mail:

\section{2) QUEIXA PRINCIPAL:}

Idade de início dos sintomas:

Primeiros sintomas:

3) HISTÓRIA CLÍNICA:

2) PERI-NATAL E DESENVOLVIMENTO:

Pré-Natal: $\square$ Sim Consultas: $\quad \square$ Não

a) Intercorrências gestacionais: $\square$ polidrâmnio $\square$ DPP $\square$ pré-eclampsia tabagismo $\square$ etilismo

b) Uso de medicações:

c) Mov. fetais: $\square$ normal $\square$ reduzido

d) Idade gestacional: $\square<35$ sem $\square$ 35-37 sem $\square$ 38-41 sem $\square>41$ sem.

e) Parto Normal $\square$ Parto Cesárea $\square \quad$ Alta hospitalar (dias):

f) Peso: Altura: PC: Apgar: $1 \mathrm{~min} / \quad 5 \mathrm{~min}$

g) Anóxia perinatal: $\square$ ausente $\square$ presente $\square$ não sabe

h) Choro após nascimento: $\square$ presente $\square$ ausente $\square$ não sabe

i) Sucção: $\square$ presente $\square$ ausente

j) Necessidade de terapia intensiva: $\square$ não, $\square<48 \mathrm{hs}, \square$ 48hs-1sem, $\square>1$ sem 
k) Complicações neonatais (hipotonia, dificuldade alimentar, deslocamento de quadril, torcicolo, micro-oftalmia, retrações, microcefalia ou macrocefalia, reanimação, oxigenioterapia , convulsões, icterícia, hipoglicemia, infecções, má DNPM: formações, outras):

a) Sustento da cabeça:

b) Mobilidade ativa dos membros: $\square$ normal $\square$ reduzida

c) Lactente hipotônico: $\square \operatorname{Sim} \square$ Não

d) Sentar com apoio: sem apoio: Engatinhar:

e) Ficar em pé com apoio: sem apoio:

f) Andar com apoio: sem apoio:

g) Lalação: Primeiras palavras: Frases gramaticais:

h) Controle esfincteriano noturno:

i) DNPM atual:

j) Denver

\section{3) HISTÓRIA PATOLÓGICA PREGRESSA:}

a) Infecções / Doenças crônicas / Internações / Cirurgias / Traqueostomia

\section{4) INTERROGATÓRIO CLÍNICO GERAL:}

a) SNC (anomalias congênitas / convulsões-tipo / queixas intelectuais e comportamentais, cefaléia, coréia, distonia, espsticidade, trasntorno déficit de atenção, Ql<70, distúrbio comportamento)

b) Cardiovascular (dispneia / ortopnéia / palpitações / síncope / tosse / cardiopatia congestiva / arritmia cardíaca / miocardiopatia)

c) Pulmonar:

BIPAP? $\operatorname{Sim} \square \quad$ não $\square$

Somente durante infecções $\square$ Somente à noite $\square>16 \mathrm{~h} /$ dia $\square$

Idade de início

Ventilação mecânica? $\operatorname{Sim} \square \quad$ não $\square$

Quantas hs/dia?

Infecção respiratória de repetição? $\operatorname{Sim} \square$ não $\square$

d) Fonoaudiológico (disfagia / disfonia / lentidão mastigatória, perda auditiva)

e) Oftalmológico (glaucoma / catarata / retinite / / atrofia óptica / oftalmoparesia / miopia / hipermetropia / astigmatismo / estrabismo / catarata / diplopia)

f) Distúrbios do sono (insônia / pesadelos / despertares noturnos / roncos / sonolência diurna)

g) Gastrointestinal (aspiração, hipersalivação, dificuldade alimentar, obstipação, hepatopatia)

h) Pele: (estrias, eczema, hiperqueratose folicular, ictiose, quelóide)

i) Endócrinológico: (diabetes, hiper/hipotireodismo, atraso puberal, baixa estatura)

j) Outros (queixas genito-urinárias / menstruação / hérnias abdominais)

5) HISTÓRIA FAMILIAR

a) Consanguinidade: $\square$ Sim Parentesco: $\square$ Não 
b) Doenças Familiares:

c) Outros acometidos na família:

\section{EXAME FÍsICO}

Geral: Peso:

$$
\text { Altura: }
$$

PC:

$(p$

)

Pulmonar (dispnéia, recrutamento mm acessória, retrações costais, diafragmática):

Cardiovascular: $\mathrm{PA}=\quad \mathrm{FC}=\quad$ ritmo $=$

Outros (hepatomegalia, esplenomegalia, gastrostomia):

Fáscies e crânio-facial (fáscies alongada / micrognatia / má-oclusão dentária / palato ogival / assimetria facial / ptose / boca em carpa / aspecto triangular do terço inferior da face / limitação ou excesso de abertura bucal / macroglossia / disfunção da ATM, baixa implantação orelha)

\section{Alterações cutâneas:}

Linguagem (<4anos) (normal, repete sons, balbucia, atraso na linguagem)

Linguagem (já adquiriu fala) (nasal, escassa, disartria, apráxica)

\section{Exame Neurológico:}

a) Cognitivo: $\square$ normal $\square$ DM leve / moderado $\square$ DM grave

b) Equilíbrio estático:

c) Equilíbrio dinâmico:

Marcha (lordótica, atáxica, espástica, pé caído)

Nos calcanhares: Nas pontas dos pés:

d) Força muscular:

Manobra beira do leito:

Tempo do Gowers:

Sustento cefálico (normal, fraqueza discreta, fraqueza grave e requer suporte)

d) ROT (patelar, aquileu, biciptal, triciptal, estiloradial):

e) Tônus: normal $\square$ reduzido $\square$ aumentado

g) Trofismo muscular (pseudohipertrofia / distribuição da hipotrofia / assimetria de grupos musculares):

h) Movimentos involuntários:

i) Coordenação axial:

j) Coordenação apendicular:

k) Sensibilidade superficial: 


\section{I) Sensibilidade profunda:}

m) Nervos cranianos:

n) Deformidades:

Coluna vertebral (cifose / escoliose em S / lordose / cirurgia prévia / espinha rígida)

Membros (mãos em garra / equinovarus-valgo / pé chato-cavo / deformidades dos dedos / hiperextensibilidade)

Contraturas/retrações/anquiloses (ombros, pescoço, dedos, tornozelos, quadril, pés, punho e joelhos)

Tórax (pectus excavatum-carinatun / em barril / abaulamentos e afundamentos / tórax em sino)

FORÇA MUSCULAR (MRC)

\begin{tabular}{|l|l|l|}
\hline \multicolumn{1}{|c|}{ MRC } & \multicolumn{1}{|c|}{ D } & \multicolumn{1}{|c|}{} \\
\hline Flexores do pescoço & 0 & 0 \\
\hline Extensores do pescoço & 0 & 0 \\
\hline Flexores do tronco & 0 & 0 \\
\hline Extensores do tronco & 0 & 0 \\
\hline Abdução do ombro & 0 & 0 \\
\hline Adução do ombro & 0 & 0 \\
\hline Flexores do ombro & 0 & 0 \\
\hline Extensores do ombro & 0 & 0 \\
\hline Flexores do cotovelo & 0 & 0 \\
\hline Extensores do cotovelo & 0 & 0 \\
\hline Extensores do punho & 0 & 0 \\
\hline Flexores do punho & 0 & 0 \\
\hline Extensão dos dedos & 0 & 0 \\
\hline Flexores do quadril & 0 & 0 \\
\hline Extensores do quadril & 0 & 0 \\
\hline Abdutores do quadril & 0 & 0 \\
\hline
\end{tabular}

\begin{tabular}{|l|l|}
\hline \multicolumn{2}{|c|}{ MRC } \\
\hline 0 & Ausência de contração muscular \\
\hline 1 & Contração muscular (sem movimento) \\
\hline 2 & Movimento que não vence gravidade \\
\hline 3 & Movimento que vence a gravidade \\
\hline 4 & Movimento que vence alguma resistência \\
\hline 5 & Força normal \\
\hline
\end{tabular}




\begin{tabular}{|l|l|l|}
\hline Adutores do quadril & 0 & 0 \\
\hline Flexores do joelho & 0 & 0 \\
\hline Extensores do joelho & 0 & 0 \\
\hline Dorsoflexão do pé & 0 & 0 \\
\hline Flexão plantar do pé & 0 & 0 \\
\hline Eversores do pé & 0 & 0 \\
\hline Inversores do pé & 0 & 0 \\
\hline
\end{tabular}

\section{Avaliação da função motora}

\begin{tabular}{|l|l|l|}
\hline Função motora & Sim & Não \\
\hline 1. Eleva a cabeça quando deitado (supino e pronado) & $\square$ & $\square$ \\
\hline 2. Sustenta a cabeça quando sentado & $\square$ & $\square$ \\
\hline 3. Rola de trás para frente & $\square$ & $\square$ \\
\hline 4. Rola de frente para trás & $\square$ & $\square$ \\
\hline 5. Senta com suporte & $\square$ & $\square$ \\
\hline 6. Senta quando posicionada, sem suporte & $\square$ & $\square$ \\
\hline 7. Assume a posição sentada sem ajuda & $\square$ & $\square$ \\
\hline 8. Tenta engatinhar, arrasta o bumbum & $\square$ & $\square$ \\
\hline 9. Posiciona-se para engatinhar & $\square$ & $\square$ \\
\hline 10. Engatinha & $\square$ & $\square$ \\
\hline 11. Tenta ficar de pé (pull to stand) & $\square$ & $\square$ \\
\hline 12. Fica de pé quando posicionado, com ajuda & $\square$ & $\square$ \\
\hline 13. Fica de pé com órteses & $\square$ & $\square$ \\
\hline 14. Fica em pé sem órteses & $\square$ & $\square$ \\
\hline 15. Anda com órteses & $\square$ & $\square$ \\
\hline 16. Anda com ajuda & $\square$ & $\square$ \\
\hline 17. Anda independentemente & $\square$ & $\square$ \\
\hline
\end{tabular}




\begin{tabular}{|l|l|l|}
\hline 18. Sobe escadas engatinhando & $\square$ & $\square$ \\
\hline 19. Sobe escadas apoiando-se no corrimão & $\square$ & $\square$ \\
\hline 20. Sobe escadas sem apoio ou ajuda & $\square$ & $\square$ \\
\hline 21. Desce escadas engatinhando & $\square$ & $\square$ \\
\hline 22. Desce escadas com ajuda do corrimão & $\square$ & $\square$ \\
\hline 23. Desce sem apoio & $\square$ & $\square$ \\
\hline 24. Eleva o braço/mão direito acima da cabeça & $\square$ & $\square$ \\
\hline 25. Eleva o braço/mão esquerdo acima da cabeça & $\square$ & $\square$ \\
\hline 26. Flete antebraço direito & $\square$ & $\square$ \\
\hline 27. Flete antebraço esquerdo & $\square$ & $\square$ \\
\hline 28. Faz extensão do punho esquerdo & $\square$ & $\square$ \\
\hline 29. Faz extensão do punho direito & $\square$ & $\square$ \\
\hline 30. Faz flexão do punho esquerdo & $\square$ & $\square$ \\
\hline 31. Faz flexão do punho direito & $\square$ & $\square$ \\
\hline
\end{tabular}

\section{EXAMES SUBSIDIÁRIOS}

1) CPK: Data do exame:

2) Aldolase:

3) TGO: TGP:

4) Outros:

5) Eletrocardiograma:

6) Ecocardiografia com doppler:

7) Holter:

8) Prova de Função Pulmonar:

9) Polissonografia:

10) Eletroencefalografia:

11) TC crânio / RM encéfalo:

12) Teste neuropsicológico:

13) R-X (coluna vertebral, tórax e bacia):

14) Oftalmológico (Fundo de olho/ lâmpada de fenda):

15) ENMG:

16) Biópsia muscular:

Número:

Data:

17) DNA: $\square$ extraído $\square$ não extraído

Data:

18) Tratamento fisioterápico em curso: 
19) Hipóteses disgnósticas:

20) programação 


\section{REFERÊNCIAS}

Abdulhaq, U. N., Daana, M., Dor, T., Fellig, Y., Eylon, S., Schuelke, M., . . . Edvardson, S. (2016). Nemaline body myopathy caused by a novel mutation in troponin T1 (TNNT1). Muscle Nerve, 53(4), 564-569. doi:10.1002/mus.24885

Agrawal, P. B., Greenleaf, R. S., Tomczak, K. K., Lehtokari, V. L., Wallgren-Pettersson, C., Wallefeld, W., . . . Beggs, A. H. (2007). Nemaline myopathy with minicores caused by mutation of the CFL2 gene encoding the skeletal muscle actin-binding protein, cofilin-2. Am J Hum Genet, 80(1), 162-167. doi:10.1086/510402

Agrawal, P. B., Strickland, C. D., Midgett, C., Morales, A., Newburger, D. E., Poulos, M. A., . . Beggs, A. H. (2004). Heterogeneity of nemaline myopathy cases with skeletal muscle alpha-actin gene mutations. Ann Neurol, 56(1), 86-96. doi:10.1002/ana.20157

Akinrinade, O., Koskenvuo, J. W., \& Alastalo, T. P. (2015). Prevalence of Titin Truncating Variants in General Population. PLoS One, 10(12), e0145284. doi:10.1371/journal.pone.0145284

Alazami, A. M., Kentab, A. Y., Faqeih, E., Mohamed, J. Y., Alkhalidi, H., Hijazi, H., \& Alkuraya, F. S. (2015). A novel syndrome of Klippel-Feil anomaly, myopathy, and characteristic facies is linked to a null mutation in MYO18B. J Med Genet, 52(6), 400-404. doi:10.1136/jmedgenet-2014-102964

Bailey, K. (1946). Tropomyosin: a new asymmetric protein component of muscle. Nature, 157, 368.

Bevilacqua, J. A., Bitoun, M., Biancalana, V., Oldfors, A., Stoltenburg, G., Claeys, K. G., ... Romero, N. B. (2009). "Necklace" fibers, a new histological marker of late-onset MTM1-related centronuclear myopathy. Acta Neuropathol, 117(3), 283-291. doi:10.1007/s00401-0080472-1

Bohm, J., Biancalana, V., Dechene, E. T., Bitoun, M., Pierson, C. R., Schaefer, E., . . L Laporte, J. (2012). Mutation spectrum in the large GTPase dynamin 2, and genotype-phenotype correlation in autosomal dominant centronuclear myopathy. Hum Mutat, 33(6), 949959. doi:10.1002/humu.22067

Bowlin, K. M., Embree, L. J., Garry, M. G., Garry, D. J., \& Shi, X. (2013). Kbtbd5 is regulated by MyoD and restricted to the myogenic lineage. Differentiation, 86(4-5), 184-191. doi:10.1016/j.diff.2013.08.002

Brooke, M. H., \& Engel, W. K. (1969). The histographic analysis of human muscle biopsies with regard to fiber types. 4. Children's biopsies. Neurology, 19(6), 591-605.

Carmignac, V., Salih, M. A., Quijano-Roy, S., Marchand, S., Al Rayess, M. M., Mukhtar, M. M., . . . Ferreiro, A. (2007). C-terminal titin deletions cause a novel early-onset myopathy with fatal cardiomyopathy. Ann Neurol, 61(4), 340-351. doi:10.1002/ana.21089

Castiglioni, C., Cassandrini, D., Fattori, F., Bellacchio, E., D'Amico, A., Alvarez, K., . . . Bevilacqua, J. A. (2014). Muscle magnetic resonance imaging and histopathology in ACTA1-related congenital nemaline myopathy. Muscle Nerve, 50(6), 1011-1016. doi:10.1002/mus.24353

Chahin, N., Selcen, D., \& Engel, A. G. (2005). Sporadic late onset nemaline myopathy. Neurology, 65(8), 1158-1164. doi:10.1212/01.wnl.0000180362.90078.dc

Chauveau, C., Bonnemann, C. G., Julien, C., Kho, A. L., Marks, H., Talim, B., . . Ferreiro, A. (2014). Recessive TTN truncating mutations define novel forms of core myopathy with heart disease. Hum Mol Genet, 23(4), 980-991. doi:10.1093/hmg/ddt494

Chu, M., Gregorio, C. C., \& Pappas, C. T. (2016). Nebulin, a multi-functional giant. J Exp Biol, 219(Pt 2), 146-152. doi:10.1242/jeb.126383

Claeys, K. G., Maisonobe, T., Bohm, J., Laporte, J., Hezode, M., Romero, N. B., . . . Stojkovic, T. (2010). Phenotype of a patient with recessive centronuclear myopathy and a novel BIN1 mutation. Neurology, 74(6), 519-521. doi:10.1212/WNL.0b013e3181cef7f9 
Clancy, R. R., Kelts, K. A., \& Oehlert, J. W. (1980). Clinical variability in congenital fiber type disproportion. J Neurol Sci, 46(3), 257-266.

Clarke, L., Fairley, S., Zheng-Bradley, X., Streeter, I., Perry, E., Lowy, E., . . Flicek, P. (2016). The international Genome sample resource (IGSR): A worldwide collection of genome variation incorporating the 1000 Genomes Project data. Nucleic Acids Res. doi:10.1093/nar/gkw829

Clarke, N. F. (2008). Skeletal muscle disease due to mutations in tropomyosin, troponin and cofilin. Adv Exp Med Biol, 642, 40-54.

Clarke, N. F., Amburgey, K., Teener, J., Camelo-Piragua, S., Kesari, A., Punetha, J., . . . Dowling, J. J. (2013). A novel mutation expands the genetic and clinical spectrum of MYH7-related myopathies. Neuromuscul Disord, 23(5), 432-436. doi:10.1016/j.nmd.2013.02.009

Clarke, N. F., Kidson, W., Quijano-Roy, S., Estournet, B., Ferreiro, A., Guicheney, P., . . North, K. N. (2006). SEPN1: associated with congenital fiber-type disproportion and insulin resistance. Ann Neurol, 59(3), 546-552. doi:10.1002/ana.20761

Clarke, N. F., Kolski, H., Dye, D. E., Lim, E., Smith, R. L., Patel, R., . . North, K. N. (2008). Mutations in TPM3 are a common cause of congenital fiber type disproportion. Ann Neurol, 63(3), 329-337. doi:10.1002/ana.21308

Clarke, N. F., \& North, K. N. (2003). Congenital fiber type disproportion--30 years on. J Neuropathol Exp Neurol, 62(10), 977-989.

Clarke, N. F., Waddell, L. B., Cooper, S. T., Perry, M., Smith, R. L., Kornberg, A. J., ... North, K. N. (2010). Recessive mutations in RYR1 are a common cause of congenital fiber type disproportion. Hum Mutat, 31(7), E1544-1550. doi:10.1002/humu.21278

Colombo, I., Scoto, M., Manzur, A. Y., Robb, S. A., Maggi, L., Gowda, V., . . Muntoni, F. (2015). Congenital myopathies: Natural history of a large pediatric cohort. Neurology, 84(1), 2835. doi:10.1212/WNL.0000000000001110

Cullup, T., Lamont, P. J., Cirak, S., Damian, M. S., Wallefeld, W., Gooding, R., . . . Jungbluth, H. (2012). Mutations in MYH7 cause Multi-minicore Disease (MmD) with variable cardiac involvement. Neuromuscul Disord, 22(12), 1096-1104. doi:10.1016/j.nmd.2012.06.007

De Cid, R., Ben Yaou, R., Roudaut, C., Charton, K., Baulande, S., Leturcq, F., . . Richard, I. (2015). A new titinopathy: Childhood-juvenile onset Emery-Dreifuss-like phenotype without cardiomyopathy. Neurology, 85(24), 2126-2135. doi:10.1212/WNL.0000000000002200

De Paula, A. M., Franques, J., Fernandez, C., Monnier, N., Lunardi, J., Pellissier, J. F., . . Pouget, J. (2009). A TPM3 mutation causing cap myopathy. Neuromuscul Disord, 19(10), 685688. doi:10.1016/j.nmd.2009.06.365

DeChene, E. T., Kang, P. B., \& Beggs, A. H. (1993). Congenital Fiber-Type Disproportion. In R. A. Pagon, M. P. Adam, H. H. Ardinger, S. E. Wallace, A. Amemiya, L. J. H. Bean, T. D. Bird, C. R. Dolan, C. T. Fong, R. J. H. Smith, \& K. Stephens (Eds.), GeneReviews(R). Seattle (WA).

Denborough, M. A., Dennett, X., \& Anderson, R. M. (1973). Central-core disease and malignant hyperpyrexia. Br Med J, 1(5848), 272-273.

Dhanoa, B. S., Cogliati, T., Satish, A. G., Bruford, E. A., \& Friedman, J. S. (2013). Update on the Kelch-like (KLHL) gene family. Hum Genomics, 7, 13. doi:10.1186/1479-7364-7-13

Donner, K., Ollikainen, M., Ridanpaa, M., Christen, H. J., Goebel, H. H., de Visser, M., . . . Wallgren-Pettersson, C. (2002). Mutations in the beta-tropomyosin (TPM2) gene--a rare cause of nemaline myopathy. Neuromuscul Disord, 12(2), 151-158.

Durling, H. J., Reilich, P., Muller-Hocker, J., Mendel, B., Pongratz, D., Wallgren-Pettersson, C., . . . Laing, N. G. (2002). De novo missense mutation in a constitutively expressed exon of the slow alpha-tropomyosin gene TPM3 associated with an atypical, sporadic case of nemaline myopathy. Neuromuscul Disord, 12(10), 947-951.

Engel, A. G., Ohno, K., \& Sine, S. M. (1998). Congenital myasthenic syndromes: experiments of nature. J Physiol Paris, 92(2), 113-117. doi:10.1016/S0928-4257(98)80147-2 
Engel, A. G., Shen, X. M., Selcen, D., \& Sine, S. M. (2015). Congenital myasthenic syndromes: pathogenesis, diagnosis, and treatment. Lancet Neurol, 14(5), 461. doi:10.1016/S14744422(15)00010-1

Feng, J. J., \& Marston, S. (2009). Genotype-phenotype correlations in ACTA1 mutations that cause congenital myopathies. Neuromuscul Disord, 19(1), 6-16. doi:10.1016/j.nmd.2008.09.005

Ferreiro, A., Monnier, N., Romero, N. B., Leroy, J. P., Bonnemann, C., Haenggeli, C. A., . . . Guicheney, P. (2002). A recessive form of central core disease, transiently presenting as multi-minicore disease, is associated with a homozygous mutation in the ryanodine receptor type 1 gene. Ann Neurol, 51(6), 750-759. doi:10.1002/ana.10231

Gerull, B., Gramlich, M., Atherton, J., McNabb, M., Trombitas, K., Sasse-Klaassen, S., . . . Thierfelder, L. (2002). Mutations of TTN, encoding the giant muscle filament titin, cause familial dilated cardiomyopathy. Nat Genet, 30(2), 201-204. doi:10.1038/ng815

Goebel, H. H., \& Warlo, I. (1997). Nemaline myopathy with intranuclear rods--intranuclear rod myopathy. Neuromuscul Disord, 7(1), 13-19.

Gommans, I. M., van Engelen, B. G., ter Laak, H. J., Brunner, H. G., Kremer, H., Lammens, M., \& Vogels, O. J. (2002). A new phenotype of autosomal dominant nemaline myopathy. Neuromuscul Disord, 12(1), 13-18.

Granzier, H. L., \& Irving, T. C. (1995). Passive tension in cardiac muscle: contribution of collagen, titin, microtubules, and intermediate filaments. Biophys J, 68(3), 1027-1044. doi:10.1016/S0006-3495(95)80278-X

Gunning, P. W., Schevzov, G., Kee, A. J., \& Hardeman, E. C. (2005). Tropomyosin isoforms: divining rods for actin cytoskeleton function. Trends Cell Biol, 15(6), 333-341. doi:10.1016/j.tcb.2005.04.007

Gupta, V. A., Ravenscroft, G., Shaheen, R., Todd, E. J., Swanson, L. C., Shiina, M., . . Beggs, A. H. (2013). Identification of KLHL41 Mutations Implicates BTB-Kelch-Mediated Ubiquitination as an Alternate Pathway to Myofibrillar Disruption in Nemaline Myopathy. Am J Hum Genet, 93(6), 1108-1117. doi:10.1016/j.ajhg.2013.10.020

Hackman, P., Vihola, A., Haravuori, H., Marchand, S., Sarparanta, J., De Seze, J., . . . Udd, B. (2002). Tibial muscular dystrophy is a titinopathy caused by mutations in TTN, the gene encoding the giant skeletal-muscle protein titin. Am J Hum Genet, 71(3), 492-500. doi:10.1086/342380

Harper, C. M. (2004). Congenital myasthenic syndromes. Semin Neurol, 24(1), 111-123. doi:10.1055/s-2004-829592

Hung, R. M., Yoon, G., Hawkins, C. E., Halliday, W., Biggar, D., \& Vajsar, J. (2010). Cap myopathy caused by a mutation of the skeletal alpha-actin gene ACTA1. Neuromuscul Disord, 20(4), 238-240. doi:10.1016/j.nmd.2010.01.011

Ilkovski, B., Cooper, S. T., Nowak, K., Ryan, M. M., Yang, N., Schnell, C., . . North, K. N. (2001). Nemaline myopathy caused by mutations in the muscle alpha-skeletal-actin gene. Am J Hum Genet, 68(6), 1333-1343. doi:10.1086/320605

Jaenicke, T., Diederich, K. W., Haas, W., Schleich, J., Lichter, P., Pfordt, M., . . Vosberg, H. P. (1990). The complete sequence of the human beta-myosin heavy chain gene and a comparative analysis of its product. Genomics, 8(2), 194-206.

Jarraya, M., Quijano-Roy, S., Monnier, N., Behin, A., Avila-Smirnov, D., Romero, N. B., ... Carlier, R. Y. (2012). Whole-Body muscle MRI in a series of patients with congenital myopathy related to TPM2 gene mutations. Neuromuscul Disord, 22 Suppl 2, S137-147. doi:10.1016/j.nmd.2012.06.347

Johnston, J. J., Kelley, R. I., Crawford, T. O., Morton, D. H., Agarwala, R., Koch, T., . . Biesecker, L. G. (2000). A novel nemaline myopathy in the Amish caused by a mutation in troponin T1. Am J Hum Genet, 67(4), 814-821. doi:10.1086/303089

Jungbluth, H., \& Gautel, M. (2014). Pathogenic mechanisms in centronuclear myopathies. Front Aging Neurosci, 6, 339. doi:10.3389/fnagi.2014.00339 
Jungbluth, H., Ochala, J., Treves, S., \& Gautel, M. (2016). Current and future therapeutic approaches to the congenital myopathies. Semin Cell Dev Biol. doi:10.1016/j.semcdb.2016.08.004

Jungbluth, H., Sewry, C. A., \& Muntoni, F. (2011). Core myopathies. Semin Pediatr Neurol, 18(4), 239-249. doi:10.1016/j.spen.2011.10.005

Jungbluth, H., Wallgren-Pettersson, C., \& Laporte, J. (2008). Centronuclear (myotubular) myopathy. Orphanet J Rare Dis, 3, 26. doi:10.1186/1750-1172-3-26

Kaindl, A. M., Ruschendorf, F., Krause, S., Goebel, H. H., Koehler, K., Becker, C., . . . Huebner, A. (2004). Missense mutations of ACTA1 cause dominant congenital myopathy with cores. J Med Genet, 41(11), 842-848. doi:10.1136/jmg.2004.020271

Kinali, M., Beeson, D., Pitt, M. C., Jungbluth, H., Simonds, A. K., Aloysius, A., ... Robb, S. A. (2008). Congenital myasthenic syndromes in childhood: diagnostic and management challenges. J Neuroimmunol, 201-202, 6-12. doi:10.1016/j.jneuroim.2008.06.026

Labeit, S., Ottenheijm, C. A., \& Granzier, H. (2011). Nebulin, a major player in muscle health and disease. FASEB J, 25(3), 822-829. doi:10.1096/fj.10-157412

Laing, N. G., Clarke, N. F., Dye, D. E., Liyanage, K., Walker, K. R., Kobayashi, Y., . . . Nonaka, I. (2004). Actin mutations are one cause of congenital fibre type disproportion. Ann Neurol, 56(5), 689-694. doi:10.1002/ana.20260

Laing, N. G., Dye, D. E., Wallgren-Pettersson, C., Richard, G., Monnier, N., Lillis, S., . . Nowak, K. J. (2009). Mutations and polymorphisms of the skeletal muscle alpha-actin gene (ACTA1). Hum Mutat, 30(9), 1267-1277. doi:10.1002/humu.21059

Laing, N. G., Wilton, S. D., Akkari, P. A., Dorosz, S., Boundy, K., Kneebone, C., . . et al. (1995). A mutation in the alpha tropomyosin gene TPM3 associated with autosomal dominant nemaline myopathy. Nat Genet, 9(1), 75-79. doi:10.1038/ng0195-75

Lehtokari, V. L., Kiiski, K., Sandaradura, S. A., Laporte, J., Repo, P., Frey, J. A., . . . WallgrenPettersson, C. (2014). Mutation update: the spectra of nebulin variants and associated myopathies. Hum Mutat, 35(12), 1418-1426. doi:10.1002/humu.22693

Lehtokari, V. L., Pelin, K., Donner, K., Voit, T., Rudnik-Schoneborn, S., Stoetter, M., . . WallgrenPettersson, C. (2008). Identification of a founder mutation in TPM3 in nemaline myopathy patients of Turkish origin. Eur J Hum Genet, 16(9), 1055-1061. doi:10.1038/ejhg.2008.60

Lehtokari, V. L., Pelin, K., Herczegfalvi, A., Karcagi, V., Pouget, J., Franques, J., . . . WallgrenPettersson, C. (2011). Nemaline myopathy caused by mutations in the nebulin gene may present as a distal myopathy. Neuromuscul Disord, 21(8), 556-562. doi:10.1016/j.nmd.2011.05.012

Lescure, A., Rederstorff, M., Krol, A., Guicheney, P., \& Allamand, V. (2009). Selenoprotein function and muscle disease. Biochim Biophys Acta, 1790(11), 1569-1574. doi:10.1016/j.bbagen.2009.03.002

Liversage, A. D., Holmes, D., Knight, P. J., Tskhovrebova, L., \& Trinick, J. (2001). Titin and the sarcomere symmetry paradox. J Mol Biol, 305(3), 401-409. doi:10.1006/jmbi.2000.4279

Lorenzoni, P. J., Scola, R. H., Kay, C. S., \& Werneck, L. C. (2012). Congenital myasthenic syndrome: a brief review. Pediatr Neurol, 46(3), 141-148. doi:10.1016/j.pediatrneurol.2011.12.001

Marra, J. D., Engelstad, K. E., Ankala, A., Tanji, K., Dastgir, J., De Vivo, D. C., . . Chiriboga, C. A. (2014). Identification of a novel nemaline myopathy-Causing mutation in the troponin T1 (TNNT1) gene: A case outside of the old order amish. Muscle Nerve. doi:10.1002/mus.24528

Marttila, M., Lehtokari, V. L., Marston, S., Nyman, T. A., Barnerias, C., Beggs, A. H., ... WallgrenPettersson, C. (2014). Mutation update and genotype-phenotype correlations of novel and previously described mutations in TPM2 and TPM3 causing congenital myopathies. Hum Mutat, 35(7), 779-790. doi:10.1002/humu.22554

Meredith, C., Herrmann, R., Parry, C., Liyanage, K., Dye, D. E., Durling, H. J., . . Laing, N. G. (2004). Mutations in the slow skeletal muscle fiber myosin heavy chain gene (MYH7) cause laing 
early-onset distal myopathy (MPD1). Am J Hum Genet, 75(4), 703-708. doi:10.1086/424760

Moghadaszadeh, B., Petit, N., Jaillard, C., Brockington, M., Quijano Roy, S., Merlini, L., . . . Guicheney, P. (2001). Mutations in SEPN1 cause congenital muscular dystrophy with spinal rigidity and restrictive respiratory syndrome. Nat Genet, 29(1), 17-18. doi:10.1038/ng713

Muelas, N., Hackman, P., Luque, H., Garces-Sanchez, M., Azorin, I., Suominen, T., . . V Vilchez, J. J. (2010). MYH7 gene tail mutation causing myopathic profiles beyond Laing distal myopathy. Neurology, 75(8), 732-741. doi:10.1212/WNL.0b013e3181eee4d5

Nance, J. R., Dowling, J. J., Gibbs, E. M., \& Bonnemann, C. G. (2012). Congenital myopathies: an update. Curr Neurol Neurosci Rep, 12(2), 165-174. doi:10.1007/s11910-012-0255-x

Natera-de Benito, D., Nascimento, A., Abicht, A., Ortez, C., Jou, C., Muller, J. S., . . Lochmuller, H. (2016). KLHL40-related nemaline myopathy with a sustained, positive response to treatment with acetylcholinesterase inhibitors. J Neurol, 263(3), 517-523. doi:10.1007/s00415-015-8015-x

North, K. N. (2011). Clinical approach to the diagnosis of congenital myopathies. Semin Pediatr Neurol, 18(4), 216-220. doi:10.1016/j.spen.2011.10.002

North, K. N., Laing, N. G., \& Wallgren-Pettersson, C. (1997). Nemaline myopathy: current concepts. The ENMC International Consortium and Nemaline Myopathy. J Med Genet, 34(9), 705-713.

North, K. N., Wang, C. H., Clarke, N., Jungbluth, H., Vainzof, M., Dowling, J. J., . . . International Standard of Care Committee for Congenital, M. (2014). Approach to the diagnosis of congenital myopathies. Neuromuscul Disord, 24(2), 97-116. doi:10.1016/j.nmd.2013.11.003

Nowak, D., \& Malicka-Blaszkiewicz, M. (1999). [Actin isoforms--functional differentiation, changes in cell pathology]. Postepy Biochem, 45(4), 261-269.

Nowak, K. J., Ravenscroft, G., \& Laing, N. G. (2013). Skeletal muscle alpha-actin diseases (actinopathies): pathology and mechanisms. Acta Neuropathol, 125(1), 19-32. doi:10.1007/s00401-012-1019-z

Nowak, K. J., Sewry, C. A., Navarro, C., Squier, W., Reina, C., Ricoy, J. R., . . Laing, N. G. (2007). Nemaline myopathy caused by absence of alpha-skeletal muscle actin. Ann Neurol, 61(2), 175-184. doi:10.1002/ana.21035

O'Grady, G. L., Best, H. A., Oates, E. C., Kaur, S., Charlton, A., Brammah, S., .. Clarke, N. F. (2015). Recessive ACTA1 variant causes congenital muscular dystrophy with rigid spine. Eur J Hum Genet, 23(6), 883-886. doi:10.1038/ejhg.2014.169

Ockeloen, C. W., Gilhuis, H. J., Pfundt, R., Kamsteeg, E. J., Agrawal, P. B., Beggs, A. H., . . van Alfen, N. (2012). Congenital myopathy caused by a novel missense mutation in the CFL2 gene. Neuromuscul Disord, 22(7), 632-639. doi:10.1016/j.nmd.2012.03.008

Ohlsson, M., Fidzianska, A., Tajsharghi, H., \& Oldfors, A. (2009). TPM3 mutation in one of the original cases of cap disease. Neurology, 72(22), 1961-1963. doi:10.1212/WNL.0b013e3181a82659

Oishi, M., \& Mochizuki, Y. (1998). Magnetic resonance imaging findings of the skeletal muscle of a patient with nemaline myopathy. Intern Med, 37(9), 776-779.

Olive, M., Goldfarb, L. G., Lee, H. S., Odgerel, Z., Blokhin, A., Gonzalez-Mera, L., . . Sambuughin, N. (2010). Nemaline myopathy type 6: clinical and myopathological features. Muscle Nerve, 42(6), 901-907. doi:10.1002/mus.21788

Palmio, J., Evila, A., Chapon, F., Tasca, G., Xiang, F., Bradvik, B., . . Udd, B. (2014). Hereditary myopathy with early respiratory failure: occurrence in various populations. I Neurol Neurosurg Psychiatry, 85(3), 345-353. doi:10.1136/jnnp-2013-304965

Pavone, P., Polizzi, A., Longo, M. R., Romano, K., Vecchio, M., Pratico, A. D., \& Falsaperla, R. (2013). Congenital myasthenic syndromes: Clinical and molecular report on 7 Sicilian patients. J Pediatr Neurosci, 8(1), 19-21. doi:10.4103/1817-1745.111416 
Peled, Y., Gramlich, M., Yoskovitz, G., Feinberg, M. S., Afek, A., Polak-Charcon, S., . . Arad, M. (2014). Titin mutation in familial restrictive cardiomyopathy. Int J Cardiol, 171(1), 24-30. doi:10.1016/j.ijcard.2013.11.037

Pelin, K., Hilpela, P., Donner, K., Sewry, C., Akkari, P. A., Wilton, S. D., . . . Wallgren-Pettersson, C. (1999). Mutations in the nebulin gene associated with autosomal recessive nemaline myopathy. Proc Natl Acad Sci U S A, 96(5), 2305-2310.

Pelin, K., \& Wallgren-Pettersson, C. (2008). Nebulin--a giant chameleon. Adv Exp Med Biol, 642, 28-39.

Ravenscroft, G., McNamara, E., Griffiths, L. M., Papadimitriou, J. M., Hardeman, E. C., Bakker, A. J., . . . Nowak, K. J. (2013). Cardiac alpha-actin over-expression therapy in dominant ACTA1 disease. Hum Mol Genet, 22(19), 3987-3997. doi:10.1093/hmg/ddt252

Ravenscroft, G., Miyatake, S., Lehtokari, V. L., Todd, E. J., Vornanen, P., Yau, K. S., . . Laing, N. G. (2013). Mutations in KLHL40 are a frequent cause of severe autosomal-recessive nemaline myopathy. Am J Hum Genet, 93(1), 6-18. doi:10.1016/j.ajhg.2013.05.004

Romero, N. B., Lehtokari, V. L., Quijano-Roy, S., Monnier, N., Claeys, K. G., Carlier, R. Y., . . . Wallgren-Pettersson, C. (2009). Core-rod myopathy caused by mutations in the nebulin gene. Neurology, 73(14), 1159-1161. doi:10.1212/WNL.0b013e3181bacf45

Romero, N. B., Monnier, N., Viollet, L., Cortey, A., Chevallay, M., Leroy, J. P., . . Fardeau, M. (2003). Dominant and recessive central core disease associated with RYR1 mutations and fetal akinesia. Brain, 126(Pt 11), 2341-2349. doi:10.1093/brain/awg244

Romero, N. B., Sandaradura, S. A., \& Clarke, N. F. (2013). Recent advances in nemaline myopathy. Curr Opin Neurol, 26(5), 519-526. doi:10.1097/WCO.0b013e328364d681

Romero, N. B., Xie, T., Malfatti, E., Schaeffer, U., Bohm, J., Wu, B., . . . Laporte, J. (2014). Autosomal dominant eccentric core disease caused by a heterozygous mutation in the MYH7 gene. J Neurol Neurosurg Psychiatry, 85(10), 1149-1152. doi:10.1136/jnnp-2013306754

Ryan, M. M., Ilkovski, B., Strickland, C. D., Schnell, C., Sanoudou, D., Midgett, C., . . Beggs, A. H. (2003). Clinical course correlates poorly with muscle pathology in nemaline myopathy. Neurology, 60(4), 665-673.

Sambuughin, N., Yau, K. S., Olive, M., Duff, R. M., Bayarsaikhan, M., Lu, S., . . Goldfarb, L. G. (2010). Dominant mutations in KBTBD13, a member of the BTB/Kelch family, cause nemaline myopathy with cores. Am J Hum Genet, 87(6), 842-847. doi:10.1016/j.ajhg.2010.10.020

Schara, U., Kress, W., Bonnemann, C. G., Breitbach-Faller, N., Korenke, C. G., Schreiber, G., . . von der Hagen, M. (2008). The phenotype and long-term follow-up in 11 patients with juvenile selenoprotein N1-related myopathy. Eur J Paediatr Neurol, 12(3), 224-230. doi:10.1016/j.ejpn.2007.08.011

Seferian, A. M., Malfatti, E., Bosson, C., Pelletier, L., Taytard, J., Forin, V., . . Servais, L. (2016). Mild clinical presentation in KLHL40-related nemaline myopathy (NEM 8). Neuromuscul Disord. doi:10.1016/j.nmd.2016.07.011

Sewry, C. A., Holton, J. L., Dick, D. J., Muntoni, F., \& Hanna, M. G. (2015). Zebra body myopathy is caused by a mutation in the skeletal muscle actin gene (ACTA1). Neuromuscul Disord, 25(5), 388-391. doi:10.1016/j.nmd.2015.02.003

Sher, J. H., Rimalovski, A. B., Athanassiades, T. J., \& Aronson, S. M. (1967). Familial centronuclear myopathy: a clinical and pathological study. Neurology, 17(8 Pt 1), 727-742.

Sherry, S. T., Ward, M. H., Kholodov, M., Baker, J., Phan, L., Smigielski, E. M., \& Sirotkin, K. (2001). dbSNP: the NCBI database of genetic variation. Nucleic Acids Res, 29(1), 308-311.

Shy, G. M., Engel, W. K., Somers, J. E., \& Wanko, T. (1963). Nemaline Myopathy. A New Congenital Myopathy. Brain, 86, 793-810.

Sparrow, J. C., Nowak, K. J., Durling, H. J., Beggs, A. H., Wallgren-Pettersson, C., Romero, N., . . . Laing, N. G. (2003). Muscle disease caused by mutations in the skeletal muscle alphaactin gene (ACTA1). Neuromuscul Disord, 13(7-8), 519-531. 
Sung, S. S., Brassington, A. M., Grannatt, K., Rutherford, A., Whitby, F. G., Krakowiak, P. A., . . . Bamshad, M. (2003). Mutations in genes encoding fast-twitch contractile proteins cause distal arthrogryposis syndromes. Am J Hum Genet, 72(3), 681-690. doi:10.1086/368294

Tajsharghi, H., Oldfors, A., \& Swash, M. (2007). Myosin storage myopathy with cardiomyopathy. Neuromuscul Disord, 17(9-10), 725. doi:10.1016/j.nmd.2007.04.011

Tan, P., Briner, J., Boltshauser, E., Davis, M. R., Wilton, S. D., North, K., . . . Laing, N. G. (1999). Homozygosity for a nonsense mutation in the alpha-tropomyosin slow gene TPM3 in a patient with severe infantile nemaline myopathy. Neuromuscul Disord, 9(8), 573-579.

Tasca, G., Ricci, E., Penttila, S., Monforte, M., Giglio, V., Ottaviani, P., . . . Udd, B. (2012). New phenotype and pathology features in MYH7-related distal myopathy. Neuromuscul Disord, 22(7), 640-647. doi:10.1016/j.nmd.2012.03.003

Tian, L., Ding, S., You, Y., Li, T. R., Liu, Y., Wu, X., . . Xu, T. (2015). Leiomodin-3-deficient mice display nemaline myopathy with fast-myofiber atrophy. Dis Model Mech, 8(6), 635-641. doi:10.1242/dmm.019430

van der Pol, W. L., Leijenaar, J. F., Spliet, W. G., Lavrijsen, S. W., Jansen, N. J., Braun, K. P., . . van Haelst, M. M. (2014). Nemaline myopathy caused byTNNT1 mutations in a Dutch pedigree. Mol Genet Genomic Med, 2(2), 134-137. doi:10.1002/mgg3.52

Wallgren-Pettersson, C., Pelin, K., Nowak, K. J., Muntoni, F., Romero, N. B., Goebel, H. H., . . . Myopathy, E. I. C. O. N. (2004). Genotype-phenotype correlations in nemaline myopathy caused by mutations in the genes for nebulin and skeletal muscle alpha-actin. Neuromuscul Disord, 14(8-9), 461-470. doi:10.1016/j.nmd.2004.03.006

Wallgren-Pettersson, C., Sewry, C. A., Nowak, K. J., \& Laing, N. G. (2011). Nemaline myopathies. Semin Pediatr Neurol, 18(4), 230-238. doi:10.1016/j.spen.2011.10.004

Wilmshurst, J. M., Lillis, S., Zhou, H., Pillay, K., Henderson, H., Kress, W., . . Jungbluth, H. (2010). RYR1 mutations are a common cause of congenital myopathies with central nuclei. Ann Neurol, 68(5), 717-726. doi:10.1002/ana.22119

Witjas-Paalberends, E. R., Piroddi, N., Stam, K., van Dijk, S. J., Oliviera, V. S., Ferrara, C., . . van der Velden, J. (2013). Mutations in MYH7 reduce the force generating capacity of sarcomeres in human familial hypertrophic cardiomyopathy. Cardiovasc Res, 99(3), 432 441. doi:10.1093/cvr/cvt119

Won, H. H., Kim, H. J., Lee, K. A., \& Kim, J. W. (2008). Cataloging coding sequence variations in human genome databases. PLoS One, 3(10), e3575. doi:10.1371/journal.pone.0003575

Wu, S., Ibarra, M. C., Malicdan, M. C., Murayama, K., Ichihara, Y., Kikuchi, H., . . . Nishino, I. (2006). Central core disease is due to RYR1 mutations in more than $90 \%$ of patients. Brain, 129(Pt 6), 1470-1480. doi:10.1093/brain/awl077

Yue, D., Gao, M., Zhu, W., Luo, S., Xi, J., Wang, B., ... Zhao, C. (2015). New disease allele and de novo mutation indicate mutational vulnerability of titin exon 343 in hereditary myopathy with early respiratory failure. Neuromuscul Disord, 25(2), 172-176. doi:10.1016/j.nmd.2014.11.005

Yuen, M., Sandaradura, S. A., Dowling, J. J., Kostyukova, A. S., Moroz, N., Quinlan, K. G., . . . Clarke, N. F. (2015). Leiomodin-3 dysfunction results in thin filament disorganization and nemaline myopathy. J Clin Invest, 125(1), 456-457. doi:10.1172/JCl80057

Zhu, X., Petrovski, S., Xie, P., Ruzzo, E. K., Lu, Y. F., McSweeney, K. M., . . . Goldstein, D. B. (2015). Whole-exome sequencing in undiagnosed genetic diseases: interpreting 119 trios. Genet Med, 17(10), 774-781. doi:10.1038/gim.2014.191

Zukosky, K., Meilleur, K., Traynor, B. J., Dastgir, J., Medne, L., Devoto, M., . . Bonnemann, C. G. (2015). Association of a Novel ACTA1 Mutation With a Dominant Progressive Scapuloperoneal Myopathy in an Extended Family. JAMA Neurol, 72(6), 689-698. doi:10.1001/jamaneurol.2015.37 
